Institute of Agricultural Chemistry

Effect of nitrogen fertilizer on nitrogen assimilation and seed quality of amaranth (Amaranthus spp.) and quinoa (Chenopodium quinoa Willd)

Doctoral Dissertation

Submitted for the degree of Doctor of Agricultural Sciences

of the Faculty of Agricultural Sciences

Georg-August-University of Göttingen

by

Sa-nguansak Thanapornpoonpong

from Phayao, Thailand

Göttingen, November 2004 
D7

Referee: Prof. Dr. Elke Pawelzik

Co-referee: Prof. Dr. Norbert Claassen

Date of oral examination: 18.11.2004 
For my family 



\title{
Effect of nitrogen fertilizer on nitrogen assimilation and seed quality of amaranth (Amaranthus spp.) and quinoa (Chenopodium quinoa Willd)
}

\begin{abstract}
Amaranth and quinoa are protein-rich pseudocereals and may be used as an alternative source for non-allergenic food products. Seed composition of amaranth (Amaranthus spp.) and quinoa (Chenopodium quinoa Willd) varieties produced under Northern Germany conditions in 2001 and 2002 was investigated. Amaranth and quinoa seeds contained high protein contents. Their amino acid content was accepted as sufficient for the human nutritional requirements. The proteins were especially rich in lysine. The insoluble dietary fiber was the main part of the dietary fiber content in the seed. Amaranth flour had more pasting viscosity than wheat flour.

The effects of nitrogen fertilizer on nitrogen assimilation and seed composition of amaranth and quinoa plants were determined. Nitrogen fertilizer application affected the increase of the grain weight, biomass, grain yield and harvest index. Nitrogen use efficiency, nitrogen utilization efficiency, nitrogen harvest index and grain yield per unit of grain nitrogen decreased with increased nitrogen fertilizer rates.

Nitrogen fertilizer application affected the increase of seed protein and linoleic acid content but decreased albumin-1 fractions. The concentrations of essential amino acids were not affected by nitrogen fertilizer application. Albumin-1 fractions had high lysine content, while albumin-2 fractions had high leucine content. Globulin fractions contained higher concentrations of essential amino acids than the other fractions, but lower content of lysine. Glutelin fractions were well balanced in their essential amino acids with exception of methionine. The dietary fiber content was not changed, whereas an increase of the pasting temperature of flours obtained from amaranth and quinoa seeds was negatively related to the nitrogen supply.

The present results showed the high potential of amaranth and quinoa seeds in human diet utilization. Nitrogen fertilizer application could be an advantage to improve the nutritional values by increasing protein content and maintaining concentrations of essential amino acids.
\end{abstract}

Key words: amaranth, quinoa, nitrogen assimilation, protein, fat, dietary fiber 

Table of contents

Page

1 Introduction 1

2 References

3 Seed Composition of Amaranth (Amaranthus spp.) and Quinoa 9

(Chenopodium quinoa Willd) Produced under

Climatic Conditions of Northern Germany

$\begin{array}{ll}3.1 \text { Introduction } & 10\end{array}$

3.2 Materials and methods 11

$\begin{array}{ll}\text { 3.2.1 Plant materials } & 11\end{array}$

3.2.2 Sample preparation 11

$\begin{array}{ll}\text { 3.2.3 Determination of chemical composition } & 13\end{array}$

$\begin{array}{ll}\text { 3.2.4 Statistical analyses } & 14\end{array}$

$\begin{array}{ll}3.3 \text { Results and Discussion } & 14\end{array}$

$\begin{array}{ll}3.4 \text { Conclusions } & 23\end{array}$

$\begin{array}{ll}3.5 \text { References } & 24\end{array}$

4 Yield and Nitrogen Assimilation of Amaranth (Amaranthus spp.) and 26

Quinoa (Chenopodium quinoa Willd)

$\begin{array}{ll}4.1 \text { Introduction } & 26\end{array}$

$\begin{array}{ll}\text { 4.2 Materials and methods } & 27\end{array}$

$\begin{array}{ll}\text { 4.2.1 Plant materials } & 27\end{array}$

$\begin{array}{ll}\text { 4.2.2 Soil mineral content } 28 & 28\end{array}$

$\begin{array}{ll}\text { 4.2.3 Nitrogen determination } & 28\end{array}$

$\begin{array}{ll}4.2 .4 \text { Nitrogen use efficiency } & 28\end{array}$

4.3 Results and Discussion $\quad 29$

4.4 Conclusions 36

4.5 Reference 36

5 Changes in pseudocereal protein fractions in relation to nitrogen fertilization 38

5.1 Introduction 38

5.2 Materials and methods 39

5.2.1 Protein extraction 39

$\begin{array}{ll}\text { 5.2.2 Protein determination } & 39\end{array}$ 
5.2.3 Protein characterization with SDS-PAGE $\quad 40$

5.3 Results and Discussion $\quad 40$

5.4 Conclusions $\quad 52$

5.5 References $\quad 52$

6 Effects of nitrogen fertilizer on pseudocereals seed composition 54

6.1 Introduction $\quad 54$

6.2 Materials and methods $\quad 56$

6.2.1 Fatty acid analysis $\quad 56$

6.3 Results and Discussion 56

6.4 Conclusions $\quad 62$

6.5 References $\quad 62$

7 Summary $\quad 64$

8 Zusammenfassung $\quad 67$

$\begin{array}{ll}\text { Appendix } & 70\end{array}$

Acknowledgements 77

$\begin{array}{ll}\text { Curriculum vitae } & 79\end{array}$ 


\section{Introduction}

Food allergy is defined as an adverse reaction to foods that is mediated immunologically and involves specific imunoglubolin E (IgE) or non-IgE mechanisms (Papageorgiou, 2001). Within the European Union, food allergies affect about 5 to 10 million people (Crevel, 2001). Wheat and other cereal grains such as rice, maize and barley are well known causes of food allergies (Nakamura, 1987). Related allergens were not observed in amaranth (Amaranthus spp.) and quinoa (Chenopodium quinoa Willd). Therefore, grains from these crops may be used as an alternative source for nonallergenic food products.

Amaranth and quinoa are protein-rich pseudocereals. They are dicotyledons consisting of starchy seeds and able to grow well even under unfavorable environmental conditions. They are more protein-rich than the main cereal crops (Ahamed et al. 1998). Furthermore, the amino acid composition of their proteins corresponds rather to the FAO standards for human nutrition than that of many other plant proteins. In addition, their fat contents are similar to other cereals, especially the unsaturated fatty acid composition and content is in a balanced spectrum.

The major quinoa producing countries are Bolivia, Peru and Ecuador. Recent data from the year 2000 showed that the quinoa production amounted to 55,000 tons from an area of 80,000 ha (Taylor and Parker, 2002). Amaranth was grown in South America and in some countries of Asia and Africa (e.g. China, India, Ethiopia, Kenya) it was cultivated too. In European countries as Austria, Czech Republic, England, Germany, Hungary, Italy, Poland, Russia and Slovakia, amaranth production is developed as well. Both China and Russia have production areas of more than 100,000 ha and grow amaranth mainly for feed use. A commercial amaranth production for human nutrition is established in Mexico, South American countries, USA, China, Poland, and Austria (Berghofer and Schoenlechner, 2002). Valuable amaranth germplasms of more than 3000 accessions are available for breeding programs (Mujica and Jacobsen, 2003). 
Quinoa belongs botanically to the Chenopodiaceae family, which is found worldwide. The majority of these family are weedy plants. The interest of quinoa as a valuable crop has been renewed because of its versatility. Quinoa is able to grow under conditions normally inhospitable to other grains. These conditions include low rainfall, high altitude, sub-freezing or high temperatures (Ahamed et al. 1998). For amaranth, the major grain-producing species are A. cruentus L., A. hypochondriacus L. and A. caudatus L. that are spread throughout the tropic and temperate zones. The hybridization of both species is useful because of their shorter plant height and earlier maturity. Recently, weed amaranth, A. hybridus L. is also used for grain production. Amaranth uses the $\mathrm{C}_{4}$ photosynthesis pathway, which has a high efficiency of carbon dioxide utilization, high photosynthesis rate at high temperature and drought tolerance (Williams and Brenner, 1995).

Amaranth and quinoa are important crops in South America since many centuries. Since the 1970's their seeds have received attention by many investigators due to the valuable sources of protein and amino acids that are deficient in other cereals. Recently, they are used in several world regions for nutritional balance improvement and the healthy food production (Ahamed et al. 1998; National Research Council, 1989).

Amaranth species have 720 to $1320 \mathrm{~g} \mathrm{~m}^{-2}$ total biomass and obtain 140 to $300 \mathrm{~g} \mathrm{~m}^{-2}$ grain, while quinoa produces 238 to $636 \mathrm{~g} \mathrm{~m}^{-2}$ total biomass and contain 215 to $294 \mathrm{~g}$ $\mathrm{m}^{-2}$ grain. The harvest indexes (HI) is ranging from 0.2 to 0.3 in amaranth and from 0.2 to 0.5 in quinoa (Aufhammer et al. 1995, Spehar et al. 1998). The fertilizer use efficiency is an important factor due to the cost of production and various environmental affects. Nitrogen is the primary limiting nutrient for grain production. Nitrogen availability and supply varied between species depending on their requirements (Sinclair and de Wit, 1975). The different efficiency in nitrogen use between levels of nitrogen supply and among genotypes of maize was reported by Moll et al. (1982). Wyss et al. (1991) described that genetic differences in assimilate uptake and remobilization by source and utilization efficiencies of sink had profound effects in the seed on its protein concentration. Kaul et al. (1996) found in linseed, rapeseed, sunflower, faba bean and white lupine that the nitrogen uptake and the amount of the nitrogen residues were correlated with the dry matter production. 
Elbehri et al. (1993) reported that amaranth grain yield responded to nitrogen fertilizer in the most environments and it also increases lodging of the plants. Myers (1998) described that with increased nitrogen fertilization from 0 to $180 \mathrm{~N} \mathrm{ha}^{-1}$ the yield increased by $43 \%$. This is in contrast to results of Bressani et al. (1987), which found that yield of amaranths were not significant effected by the fertilizer rate. In amaranth, effects of environmental conditions on yield have been reported. The semidwarf cultivar 'K432' produced low grain yield in dry environments but the highest grain yield was obtained under cool and moist conditions (Henderson et al. 2000).

The content of nutrients in amaranth seeds is similar to that of quinoa seeds in regard to protein, fat and carbohydrate contents, but it is higher in crude fiber content than that of quinoa. The seeds of both pseudocereals contain higher quantity and quality of protein than the major cereals. Wild and cultivated amaranth and quinoa plants vary in their grain protein content from 13 to $21 \% \mathrm{DM}$ and 12 to $19 \% \mathrm{DM}$ respectively (Ahamed et al. 1998; National Research Council, 1989, Zhelenov et al. 1997). The

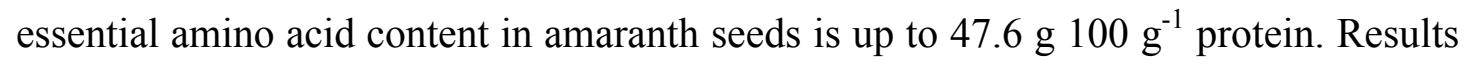
about protein fractions, protein patterns and main amino acids in amaranth and quinoa seeds have been reported by several researchers (Table 1, 2 and 3).

Table 1 Protein fractions as percentage of total protein of amaranth seeds [Protein fractions: Alb-1, albumin-1; Alb-2, albumin-2; Glo, globulin; Glut, glutelin; Prol, prolamin (\% total protein)]

\begin{tabular}{ccccccl}
\hline Alb-1 & Alb-2 & Glo & Glut & Prol & Rest & \multicolumn{1}{c}{ Source } \\
\cline { 1 - 5 } & & 19.2 & 44.4 & 2.2 & 13.4 & Bressani and Garcia-Vela (1990) \\
20.7 & 61.3 & & 24.1 & 1.4 & - & Gorinstein and Moshe (1991) \\
34 & 4 & 19 & - & - & - & Gorinstein et al. (2001) \\
- & - & - & 26.9 & 1.8 & - & Gorinstein et al. (2002) \\
\hline
\end{tabular}




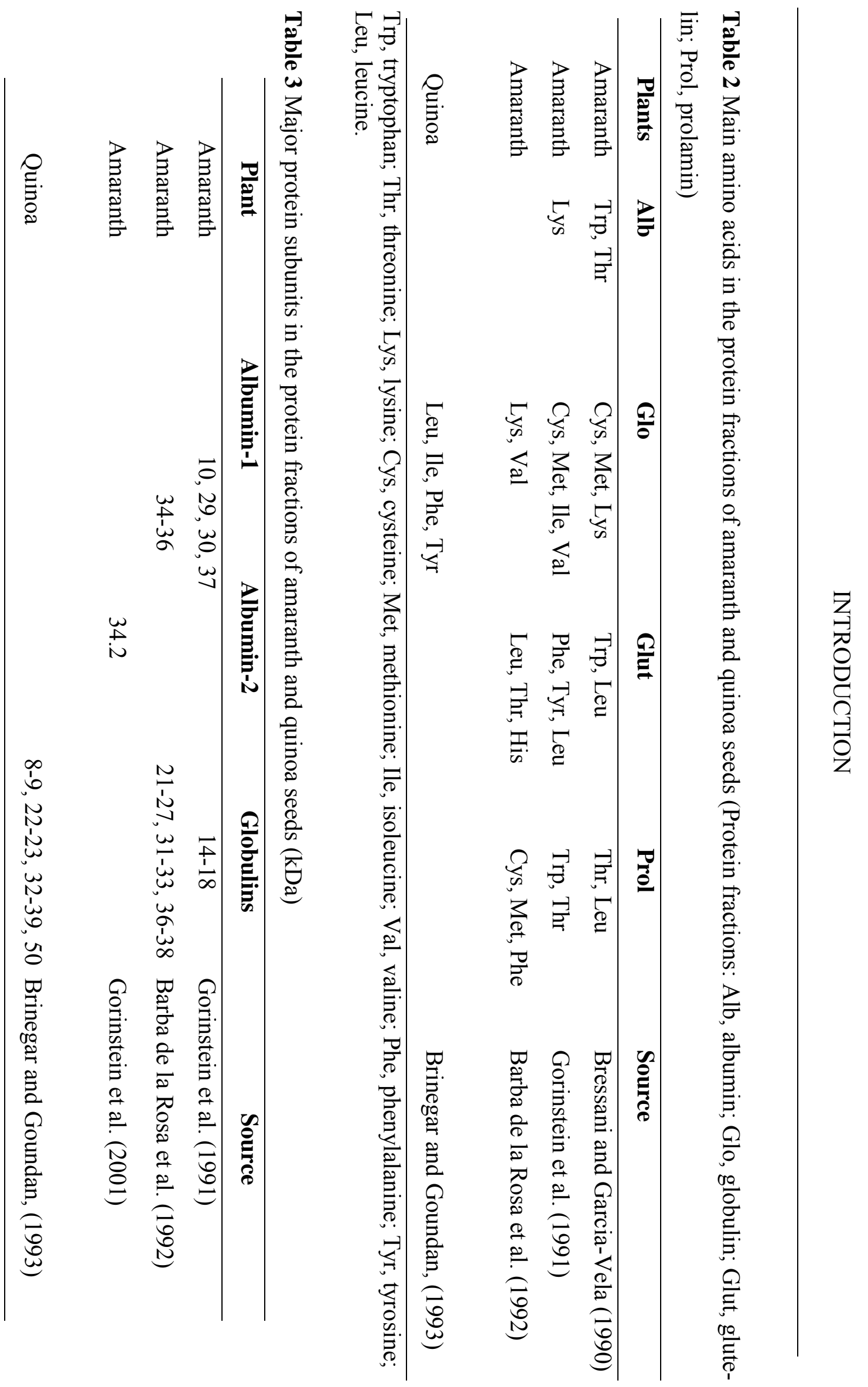


The fat content varied from 0.8 to $19 \% \mathrm{DM}$ in amaranth and approximately from 5 to $10 \%$ DM in quinoa (Ruales and Nair 1993; Wood et al. 1993). The fatty acid compositions of amaranth and quinoa are similar to that of soybean. Linoleic acid is the dominant fatty acid, followed by oleic and palmitic acid (Singhal and Kulkarni, 1988; Prakash and Pal 1992; Prakash et al. 1995; Sauerbeck et al. 2002). In quinoa, the ratio of polyunsaturated to saturated fatty acids (PS ratio) is 4.9. This is higher than the PS ratios of the most edible oils, such as oil from soybean (3.92), corn (4.65), and olive (0.65). Quinoa contains starch from 58\% to 64\% DM. The total mineral content of quinoa is similar to amaranth $(3 \%$ to $4 \% \mathrm{DM})$. Pentosans are part of the plant cell wall. The content of pentosan is usually calculated as the sum of the anhydrous arabinose and xylose residues in the dietary fiber. Pentosan content ranged from $3 \%$ to $4 \%$ DM in quinoa (Ahamed et al. 1998). Dietary fiber is an important nutrient for human digestion system. Amaranth contains about $15.2 \%$ of total dietary fiber (TDF) (USDA, 2003), whereas quinoa seed contains $13.4 \%$ TDF with 11\% insoluble dietary fiber (IDF) and 2.3\% soluble dietary fiber (SDF). The physico-chemical properties of quinoa flour was found to be different from that of wheat flour due to it is higher viscosity and stability than wheat flour (Ruales and Nair, 1994).

Recently, pseudocereals have been interested for the mass production in several European countries (Jacobsen et al. 1994; Jacobsen 1997; Aufhammer et al. 1995). However, knowledge about amaranth and quinoa seed composition is still marginal. The determination of the seed chemical composition is necessary for the variety evaluation, on the basis of a high nutritive value for human diet. Hence, the nitrogen use efficiency and effect of nitrogen fertilizer on seed composition of amaranth and quinoa productions under the Western European climatic conditions are necessary to investigate. 
Therefore, the main objectives of this study were

1. to evaluate the chemical composition of the seeds from various amaranth species and quinoa produced under Western European climatic conditions.

2. to assess the effect of nitrogen supply on biomass, grain yields, nitrogen uptake and its assimilation from the soil to the vegetative and grain parts of amaranth and quinoa.

3. to investigate the effect of nitrogen fertilizer application on the chemical composition of the seeds in various amaranth and quinoa varieties.

4. to focus more on the effects of nitrogen fertilizer application on the protein, essential amino acids contents and dietary fiber of various amaranth and quinoa species in order to approve them as the good alternative for human diet. 


\section{References}

Ahamed NT, Singhal RS, Kulkarni PR, Pal M, A lesser-known grain, Chenopodium quinoa: Review of the chemical composition of its edible parts. Food and Nutr. Bull. 1998, 19:61-70.

Aufhammer W, Kaul HP, Herz P, Nalborezyk E, Dalbiak A, Gontarczyk M, Grain yield formation and nitrogen uptake of amaranth. Eur. J. Agron 1995, 4:379-386.

Barba de la Rosa AP, Gueguen J, Paredes -López O, Viroben G, Fractionation procedures, electrophoretic characterization, and amino acid composition of amaranth seed proteins. J. Agri. Food Chem. 1992, 40:931-936.

Berghofer E, Schoenlechner R, Grain amaranth in Pseudocereals and Less Common Cereals. Ed by Belton PS, Taylor JRN. 2002, Springer-Verlag, Berlin, pp. 219-260.

Bressani R, Gonzalez JM, Elias LG, Melgar M, Effect of fertilizer application on the yield, protein and fat content, and protein quality of raw and cooked grain of three amaranth species. Plant Food Hum. Nutr. 1987, 37: 59-67

Bressani R, Garcia-Vela LA, Protein fractions in amaranth grain and their chemical characterization. J. Agri. Food Chem. 1990, 38:1205-1209.

Brinegar C, Goundan S, Isolation and characterization of chenopodin, the $11 \mathrm{~S}$ seed storage protein of quinoa (Chenopodium quinoa). J. Agri. Food Chem. 1993, 41:182-185.

Crevel, R. Industrial dimentions of food allergy. Biochem. Soc. Trans. 2001, 30:941-944.

Elbehri A, Putnam DH, Schmitt M, Nitrogen fertilizer and cultivar effects on yield and nitrogenuse efficiency of grain amaranth. Agron. J. 1993, 85:120-128.

Gorinstein S, Moshe R, Greene LJ, Arruda P, Evaluation of four Amaranthus species through proteins electrophoretic patterns and their amino acid composition. J. Agri. Food Chem. 1991, 39:851-854.

Gorinstein S, Delgado-Licon E, Pawelzik E, Permady HH, Weisz M, Trakhtenberg S, Characterization of soluble amaranth and soybean proteins based on fluorescence, hydrophobicity, electrophoresis, amino acid analysis, circular dichroism, and differential scanning calorimetry measurements. J Agric Food Chem 2001, 49:5595-5601.

Gorinstein S, Pawelzik E, Delgado-Licon E, Haruenkit R, Weisz M, Trakhtenberg S, Characterization of pseudocereal and cereal proteins by protein and amino acid analyses. J. Sci. Food Agri. 2002, 82:886-891.

Henderson TL, Johnson BL, Schneiter AA, Row spacing, plant population, and cultivar effects on grain amaranth in the northern great plains. Agron. J. 2000, 92:329-336.

Jacobsen SE, Jørgensen I, Stølen O, Cultivation of quinoa (Chenopodium quinoa) under temperate climatic conditions in Denmark. J. Agric. Sci. 1994, 122:47-52.

Jacobsen SE, Adaptation of quinoa (Chendopodium quinoa) to Northern European agriculture: studies on developmental pattern. Euphytica 1997, 96:41-48.

Kaul H-P, Aufhammer W, Wägner W, Dry matter and nitrogen accumulation and residues of oil and protein crops. Eur. J. Agron. 1996, 5:137-147.

Kreft I, Skrabanja V, Ikeda S, Ikeda K, Francisci R, Bonafaccia G, Neue ernährungsphysiologische Aspekte von Buchweizen Lebensmitteln. Getreide Mehl Brot 1998, 52:27-30.

Kuhn M, Wagner S, Aufhammer W, Lee JH, Kübler E, Schreiber H, Einfluß von pflanzenbaulicher Maßnahmen auf die Mineralstoffgehalte von Amaranth, Buchweizen, Reismelde und Hafer. Dt Lebensm Rundschau 1996, 92:147-152.

Moll RH, Kamprath EJ, Jackson WA, Analysis and interpretation of factors which contribute to efficiency of nitrogen utilization. Agron J. 1982, 74:562-564.

Mujica A, Jacobsen SE, The genetic resources of Andean grain amaranths (Amaranthus caudatus L., A. cruentus L. and A. hypochondriacus L.). PGR Newsletter 2003, 133:41-44.

Myers R, Nitrogen fertilizer effect on grain amaranth. Agron. J. 1998, 90:597-602. 
Nakamura, R. Allergens in cereals. Chem. Biol. 1987, 25:739-741.

National Research Council, Lost Crops of the Incas: Little-known plants of the Andes with promise for worldwide cultivation. 1989, National Academy Press, Washington, D.C.

Papageorgiou, P. S. Clinical aspects of food allergy. Biochem. Soc. Trans. 2001, 30:901-906.

Prakash D, Pal M, Seed protein, fat and fatty acid profile of Amaranthus species. J. Sci. Food Agri. 1992, 58:145-147.

Prakash D, Joshi BD, Pal M, Vitamin C in leaves and seed oil composition of the Amaranthus species. Inter J. Food Sci. and Nutr. 1995, 46:47-51.

Ruales J, Nair BM, Contents of fat, vitamins and minerals in quinoa (Chenopodium quinoa willd.) seed. Food Chem. 1993, 48:131-137.

Ruales J, Nair BM, Properties of starch and dietary fibre in raw and processed quinoa (Chenopodium quinoa willd) seeds. Plant Food Hum. Nutr. 1994, 45:223-246.

Sampson HA, Legumes, eggs and milk. Allergy 1998, 53:38-43.

Sauerbeck G, Stolzenburg K, Schweiger P, Schroeter C, Wilhelm E, Matthäus B, Anbau von Amaranth und Quinoa in Norddeutschland: Kornqualität am Beispiel von Fettuntersuchungen. Getreide, Mehl und Brot 2002, 56:330-333.

Sinclair TR, de Wit CT, Photosynthate and nitrogen requirements for seed production by various crops. Science 1975, 18:565-567.

Singhal R, Kulkarni PR, Composition of the seeds of some Amaranthus species. J. Sci. Food Agri. 1988, 42:325-331.

Spehar CR, Santos RLB, Jacobsen SE, Andean grain crop introduction to the Brazilian Savannah. In: International Conference on Sustainable Agriculture on Tropical and Subtropical Highlands with Special Reference to Latin America, 1998, Rio de Janeiro, Brazil.

Taylor JRN, PARKER ML, Quinoa. In: Pseudocereals and less common cereals. Ed by Belton PS, Taylor JRN. 2002, Springer-Verlag, Berlin, pp. 93-122.

USDA, Amaranth. Food Group 20 Cereal Grains and Pasta. USDA Nutrient Database for Standard Reference, Release 16. 2003, pp 1-2.

Williams JT, Brenner D, Grain amaranth (Amaranthus species). In: Cereals and pseudocereals. Ed By Williams JT. 1995, Chapman and Hall. London. pp129-186.

Wood SG, Lawson LD, Fairbanks DJ, Robinson LR, Anderson WR, Seed lipid content and fatty acid composition of three quinoa cultivars. J. Food Comp. and Anal. 1993, 6:41-44.

Wyss CS, Czyzewicz JR, Below FE, Source-sink control of grain composition in maize strains divergently selected for protein concentration. Crop Sci. 1991, 31:761-766.

Zheleznov AV, Solonenko LP, Zheleznova NB, Seed proteins of the wild and the cultivated Amaranthus species. Euphytica 1997, 97:177-182. 


\title{
3 Seed Composition of Amaranth (Amaranthus spp.) and Quinoa (Chenopodium quinoa Willd) Produced under Climatic Conditions of Northern Germany
}

\begin{abstract}
Seed composition of sixteen varieties of three amaranth species (A. cruentus, A. hybridus, A. edulis), three breeding varieties of amaranth (Koniz, RD2 and CO2CX55) and two breeding varieties of quinoa were investigated in this study. The results showed the effect of interaction between genetics (G) and environment (E) on the seed composition. The seeds of amaranth and quinoa contained 12.77 and $13.12 \%$ DM of protein, and 5.69 and $5.99 \%$ DM of fat, respectively. Quinoa seeds had higher essential amino acid (EAA) contents than amaranth seeds. The dominant essential amino acids were lysine (Lys) and phenylalanine (Phe). Their values were sufficient according to the $\mathrm{WHO} / \mathrm{FAO}$ standard requirement for human diet. The starch contents of amaranth and quinoa varieties were with 55.14 and $51.84 \%$ DM lower than that of wheat and rye. The amaranth and quinoa seeds consisted of $7.64 \%$ DM of total dietary fiber (TDF) with a ratio of insoluble dietary fiber (IDF) and soluble dietary fiber (SDF) of 3:1. Furthermore, amaranth seeds contained less pentosans than quinoa seeds. Their flour showed high values of pasting viscosity (PV) and final viscosity (FV). The differences in the chemical composition were statistically significant. Protein and fat contents were not correlated with each other, whereas the starch content was positively correlated with the dietary fiber and total mineral contents. The results indicated that breeding programs need to consider and improve the protein content in quinoa.
\end{abstract}

Key words: amaranth; quinoa; protein; fat; dietary fiber; starch; pasting properties 


\subsection{Introduction}

Amaranth (Amaranthus spp.) and quinoa (Chenopodium quinoa Willd) are pseudocereals. They are dicotyledons consisting of starchy seeds and able to grow well even under poor environmental conditions. Both of them are important crops in South America since many centuries. Since the 1970's their seeds have been received the attention by many investigators due to the valuable sources of protein and amino acids that are deficient in other cereals (Ahamed et al., 1998). Recently, they became attractive crops using for food and pharmaceuticals production (Jauregui et al., 2000; León-Camacho et al., 2001). Their protein contents composed of higher lysine concentration (5.1 - $6.3 \mathrm{~g} \mathrm{AA} 100 \mathrm{~g}^{-1}$ protein) compared with that of cereals such as wheat, maize and oat (Ahamed et al., 1998). The amino acid composition of amaranth and quinoa seeds is similar to the values of nutritional requirements for the human diet (Ahamed et al., 1998). The content of nutrients in amaranth seeds is comparable to that of quinoa seeds in protein, fat and carbohydrate contents, but it is higher in crude fiber content than quinoa. It was found that amaranth contained about 10 to 21\% DM protein (Zheleznov et al., 1997; Prakash and Pal, 1992), while the protein content of quinoa was ranged between 12 and $19 \%$ DM (Ahamed et al., 1998). The

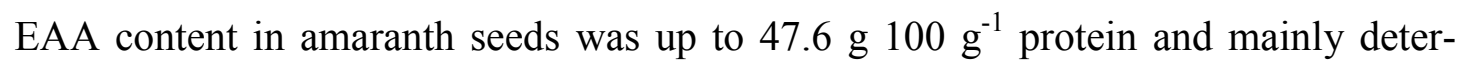
mined by isoleucine (Ile), leucine (Leu), phenylalanine (Phe), valine (Val), histidine (His) and methionine (Met) (Gorinstein et al., 2002). In quinoa, the seed protein was rich in His, cysteine (Cys), arginine (Arg) and lysine (Lys) (Brinegar, 1997). The fat content varied from 4.4 to $13.2 \%$ in amaranth (Prakash et al., 1995) and approximately from 5.1 to 9.7 \% DM in quinoa (Ruales and Nair, 1993; Wood et al., 1993). The fatty acid compositions of amaranth and quinoa were similar to that of wheat (Ahamed et al., 1998). Linoleic acid was the dominant fatty acid, followed by oleic and palmitic acid (Singhal and Kulkarni, 1988; Prakash and Pal, 1992; Prakash et al., 1995; Sauerbeck et al., 2002). Dietary fiber is an important nutrient for the human digestion system. Amaranth contains about $15.2 \%$ of TDF (USDA, 2003) whereas quinoa seed contains $13.4 \%$ TDF with $11.0 \%$ IDF and $2.4 \%$ SDF. The physicochemical properties of quinoa flour differed in pasting properties due to a higher viscosity compared to cereal flours, e.g. wheat flour (Ruales and Nair, 1994). 
In Europe, the potential use of these crops as alternative crops has remained under investigation (Jacobsen et al., 1992). Since 1992, amaranth has been investigated in southern regions of Germany (Aufhammer et al., 1995). Preliminary data on its agronomic performance was also studied in northern regions of Germany by the Federal Agricultural Research Center, Braunschweig. The determination of the chemical composition of the seeds is necessary for the variety evaluation. Therefore, this study was aimed to investigate the seed chemical composition of various amaranth species and quinoa.

\subsection{Materials and methods}

\subsubsection{Plant materials}

Nineteen varieties (sixteen varieties and three breeding varieties) of amaranth and two breeding varieties of quinoa were cultivated at the Federal Agricultural Research Center, Braunschweig, Germany in the years 2001 and 2002 (Table 1). The site condition used for this experiment was provided at a sandy loamy soil (dystric Cambisol) with $8.5^{\circ} \mathrm{C}$ and $650 \mathrm{~mm}$ precipitation as the long-term medium. The planting density was 60 plants $\mathrm{m}^{-2}$ in both years. All plots were fertilized with $60 \mathrm{~kg} \mathrm{~N}^{-1}$ (ammonium nitrate) and $120 \mathrm{~kg} \mathrm{~K}_{2} \mathrm{O} \mathrm{ha}^{-1}$ (potassium chloride). The experimental fields were plotted with the size of $15 \mathrm{~m}^{2}$ in the year 2001 and $18 \mathrm{~m}^{2}$ in the year 2002. The sowing was on $19^{\text {th }}$ May in 2001, and $16^{\text {th }}$ May in 2002 . The samples were subsequently harvested on $16^{\text {th }}$ October 2001, and $15^{\text {th }}$ September in 2002, respectively.

In addition, seeds of four amaranth varieties and two quinoa varieties from different European countries were used for the determination of the nutritional value in comparison to the samples of our interest as described above (Table 3.1).

\subsubsection{Sample preparation}

Seed samples were cleaned and dried as needed before analysis. Seed composition analyses were conducted at the Institute of Agricultural Chemistry, Georg-August University of Goettingen. Whole mature seeds of amaranth and quinoa were ground on a Laboratory mill 120 (Perten Instruments AB, Huddinge, Sweden) through a 60mesh screen and stored at $4^{\circ} \mathrm{C}$ in airtight plastic bottles until use. 
Table 3.1: Varieties, species and the origin of amaranth and quinoa

\begin{tabular}{|c|c|c|c|c|c|}
\hline Code No. & Variety & Species & Origin & Cultivation & Year \\
\hline \multicolumn{6}{|c|}{ Amaranth } \\
\hline $1^{\mathrm{a}}$ & AMR & A. cruentus & Czech Republic & Czech Republic & 2001 \\
\hline 2 & D001-A & A. cruentus & Czech Republic & Germany & 2001 \\
\hline 3 & NO-17 & A. cruentus & Czech Republic & Germany & 2001 \\
\hline 4 & Bärnkraft & A. cruentus & Germany & Germany & 2001 \\
\hline 5 & Pastevny & A. hypochondriacus & Russia & Germany & 2001 \\
\hline $6^{\mathrm{b}}$ & $\mathrm{RD} 2 / 01$ & A. hybridus & Austria & Austria & 2001 \\
\hline 7 & $\mathrm{RRC}$ & A. cruentus & Argentina & Germany & 2002 \\
\hline 8 & Tibet & A. cruentus & China & Germany & 2002 \\
\hline 9 & A-2002-D & A. cruentus & Czech Republic & Germany & 2002 \\
\hline 10 & Ames & A. cruentus & Czech Republic & Germany & 2002 \\
\hline $11^{\mathrm{c}}$ & NO-17 & A. cruentus & Czech Republic & Germany & 2002 \\
\hline 12 & $\mathrm{OPC}$ & A. cruentus & Czech Republic & Germany & 2002 \\
\hline 13 & Elbrus & A. edulis & Czech Republic & Germany & 2002 \\
\hline $14^{\mathrm{c}}$ & Koniz & A. cruentus $\mathrm{x}$ & Czech Republic & Germany & 2002 \\
\hline 15 & Bärnkraft & $\begin{array}{l}\text { A. hypochondriacus } \\
\text { A. cruentus }\end{array}$ & Germany & Germany & 2002 \\
\hline 16 & Amont & A. cruentus & USA & Germany & 2002 \\
\hline 17 & K266 & A. cruentus & USA & Germany & 2002 \\
\hline 18 & K283 & A. cruentus & USA & Germany & 2002 \\
\hline 19 & K436 & A. cruentus & USA & Germany & 2002 \\
\hline 20 & Montana & A. cruentus & USA & Germany & 2002 \\
\hline 21 & Pastevny & A. hypochondriacus & Russia & Germany & 2002 \\
\hline 22 & $\mathrm{RD} 2 / 01$ & A. hybridus & Austria & Germany & 2002 \\
\hline $23^{\mathrm{d}}$ & Rawa & A. cruentus & Poland & Poland & 2002 \\
\hline $24^{\mathrm{b}}$ & $\mathrm{CO} 2 \mathrm{CX} 55$ & A. hybridus & Austria & Austria & 2002 \\
\hline \multicolumn{6}{|l|}{ Quinoa } \\
\hline $25^{\mathrm{e}}$ & $\mathrm{S} 7 / 01$ & Chenopodium quinoa & Austria & Austria & 2001 \\
\hline $26^{\mathrm{e}}$ & S407EB/01 & Chenopodium quinoa & Austria & Austria & 2001 \\
\hline 27 & $\mathrm{~S} 7 / 02$ & Chenopodium quinoa & Austria & Austria & 2002 \\
\hline 28 & S407EB/02 & Chenopodium quinoa & Austria & Austria & 2002 \\
\hline 29 & $\mathrm{~S} 7 / 01$ & Chenopodium quinoa & Germany & Germany & 2002 \\
\hline 30 & S407EB/01 & Chenopodium quinoa & Germany & Germany & 2002 \\
\hline
\end{tabular}




\subsubsection{Determination of the chemical composition}

Crude protein content was determined by the Dumas combustion method with the automated LECO CN analyzer model CN2000 (LECO, St. Joseph, MI), and the protein conversion factor of 5.85 was used (Sweeney and Rexroad, 1987).

Amino acid composition was analyzed according to Gorinstein et al. (2002). Derivatization was done with 6-aminoquinolyl- $N$-hydroxysuccinimidyl carbamate (Cohen and Michaud, 1993). The sample was injected into a Multi-Pump Gradient HPLC system (Waters, Milford, MA) with a vertex pre-column spherimage ODS2; $5 \mu \mathrm{m}, 5 \mathrm{X} 4 \mathrm{~mm}$ and a vertex separation column, spherimage-80 ODS2; $5 \mu \mathrm{m}, 4.6 \mathrm{X}$ $150 \mathrm{~mm}$ (Knauer, Germany). The Millenium chromatography manager system (Waters, Milford, MA) was used to evaluate the amino acids content. Scanning fluorescence detector was used at an excitation of $250 \mathrm{~nm}$ and emission of $395 \mathrm{~nm}$. Gradient program was provided with sodium acetate phosphate buffer and acetonitrile/water solution (60/40; v/v). Tryptophan was not determined. The results are given as g AA $100 \mathrm{~g}^{-1}$ protein.

The fat content was carried out by means of Soxhlet extraction according to ICC standard No. 136 (ICC Standards, 1999).

The starch content was determined polarimetrically using hydrochloric acid according to the ICC Standard No. 123/1 (ICC Standards, 1999). The magnitude of specific optical rotation or Ewers factor for amaranth and quinoa were 180.1 and 187.0 grd.ml g. $\mathrm{dm}^{-1}$ as followed (Mundigler, 1998).

The determination of the total mineral content (crude ash) was followed by the ICC standard No. 104/1 (ICC Standards, 1999).

For the total dietary fiber and insoluble dietary fiber determination, an enzymaticgravimetric method was used (Asp et al., 1983; AOAC, 1984). Soluble dietary fiber was calculated as the difference between total and insoluble dietary fiber.

The determination of pasting properties of seed flour was followed by the ICC standard No. 162 (ICC Standards, 1999). A Rapid Visco Analyzer model RVA super 3 (Newport Scientific Pty Ltd., Australia) was applied. The RVA test profile was used as the standard profile 1 of the general pasting method (Anonymous, 1998). The values of viscosity were recorded in centipoise units $(\mathrm{cP})$. Abbreviations used in this study are peak viscosity (PV), highest viscosity during heating; trough (T), lowest viscosity after cooling started; breakdown (BD), peak viscosity minus trough; final 
viscosity $(\mathrm{FV})$, highest viscosity after the temperature had returned to $50^{\circ} \mathrm{C}$; setback (SB), final viscosity minus trough and pasting temperature (PT), temperature at which the trace left the baseline. Commercial wheat cv. Hanseat which was grown and harvested in 1999 at the field station Reinshof, University of Goettingen, was applied for comparison.

The pentosans content was determined colorimetrically according to the method of Dörfer (1999).

\subsubsection{Statistical analyses}

Data was evaluated by analysis of variance, and means were tested by least significant difference (LSD). The $p$ values of $<0.05$ were considered as significant. The statistical analyses were performed by using Statistix 7.0 (Analytical Software, Tallahassee, FL).

\subsection{Results and Discussion}

\subsubsection{Protein}

The chemical composition of amaranth and quinoa seeds is shown in Table 3.2. The seed protein contents of various amaranth species and quinoa were significantly different. In amaranth, they ranged from 10.90 ('9') to $15.81 \% \mathrm{DM}$ ('11') and in quinoa from 11.38 ('30') to $16.89 \% \mathrm{DM}$ ('26') The average values of crude protein content of amaranth and quinoa seeds were 12.77 and $13.12 \% \mathrm{DM}$, respectively. The hybrid variety 'Koniz' ('14') showed significantly higher seed protein content than the other Amaranthus species.

A. cruentus contained slightly more proteins than A. hypochondriacus, which was similar to the results reported by Bressani et al. (1987). However, the differences in protein content within the species of amaranth were not significant. The values obtained for quinoa in this study were in agreement with earlier data reported by Ruales and Nair (1992). In addition, the protein contents of amaranth and quinoa were comparable to that of wheat $(14 \% \mathrm{DM})$, oats $(14 \% \mathrm{DM})$ and maize $(13 \% \mathrm{DM})$ (Ahamed et al., 1998).

Under the climatic conditions of northern Germany, it was found that amaranth variety 'NO-17' showed with $15.81 \% \mathrm{DM}$ in 2002 the highest protein content. When 
compared the average protein yields of seed materials collected from the other countries with the seeds growing under northern Germany conditions, they were similar in the protein content, except for the seed material variety '23' from Poland. The planting seasons affected also the seed protein content. In the planting season 2001, the cultivars 'Bärnkraft', 'Pastevny' and 'RD2/01' had significant higher protein contents than in 2002, while in the planting season 2002, the cultivar 'NO-17' contained more protein than in 2001 .

In quinoa, the effects of the climatic conditions on the level of protein content were distinctly demonstrated. Quinoa seeds grown under northern Germany conditions contained lower protein content than that collected from Austria. Furthermore, the protein content of the Austrian seed material was also influenced by the season. Risi and Galwey (1991) reported also the effect of interaction between genotype and environment on the agronomic characters of quinoa. Hence, the interaction between genotype and environment could have an effect on seed chemical composition. However, the variations of protein content were not correlated with other compounds.

\subsubsection{Amino acid composition}

In Table 3.3 the amino acid composition of amaranth and quinoa seeds is presented. The following amino acids were analyzed: aspartic acid (Asp), serine (Ser), glutamic acid (Glu), glycine (Gly), arginine (Arg), alanine (Ala), proline (Pro), histidine (His), threonine (Thr), cysteine (Cys), methionine (Met), tyrosine (Tyr), phenylalanine (Phe), valine (Val), lysine (Lys), isoleucine (Ile), leucine (Leu). Furthermore, the sum of essential amino acids (EAA) was calculated. The EAA contents of amaranth and quinoa seeds varied from 37.59 ('21') to 43.76 ('14'), and from 41.44 ('29') to 47.14 g AA $100 \mathrm{~g}^{-1}$ protein ('26'), respectively. The amaranth seeds contained lower EAA

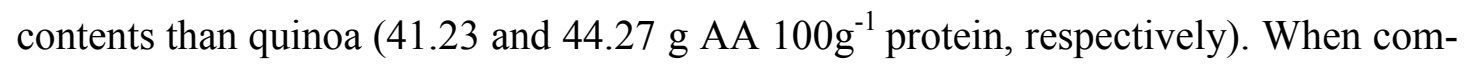
pared between the several species of Amaranthus, A. cruentus and A. edulis showed higher EAA contents than A. hypochondriacus. A. cruentus contained high concentrations of Thr, Tyr and Met. With respect to the protein quality, the variety 'D001-A' could be the most interesting variety for further breeding proposes because it contained both high EAA and protein concentrations. 
Table 3.2: Contents of protein, fat, starch, total mineral (TM), total dietary fiber (TDF), insoluble dietary fiber (IDF), soluble dietary fiber (SDF) and pentosans in the seeds of amaranth and quinoa (\% DM)

\begin{tabular}{|c|c|c|c|c|c|c|c|c|}
\hline \multirow[t]{2}{*}{ Code No. } & \multicolumn{2}{|c|}{ Protein Fat } & \multirow[t]{2}{*}{ Starch } & \multirow[t]{2}{*}{ TM } & \multicolumn{4}{|c|}{ Dietary fiber } \\
\hline & & & & & TDF & IDF & SDF & Pentosans \\
\hline \multicolumn{9}{|l|}{ Amaranth } \\
\hline 1 & 12.69 & 6.41 & 53.01 & 3.46 & 7.67 & 6.28 & 1.39 & 3.02 \\
\hline 2 & 14.71 & 6.08 & 50.64 & 3.48 & 7.00 & 6.02 & 0.98 & 3.52 \\
\hline 3 & 13.40 & 5.94 & 55.19 & 3.21 & 6.70 & 4.35 & 2.35 & 4.17 \\
\hline 4 & 13.02 & 6.64 & 61.21 & 3.33 & 7.73 & 4.69 & 3.04 & 2.96 \\
\hline 5 & 13.65 & 4.71 & 51.66 & 3.62 & 14.81 & 14.19 & 0.62 & 2.43 \\
\hline 6 & 11.91 & 4.64 & 55.53 & 2.81 & 6.10 & 5.16 & 0.94 & 3.10 \\
\hline 7 & 11.95 & 6.68 & 53.09 & 3.55 & 6.75 & 5.35 & 1.40 & 2.88 \\
\hline 8 & 11.87 & 6.50 & 56.11 & 3.24 & 6.77 & 4.76 & 2.00 & 3.11 \\
\hline 9 & 10.90 & 6.44 & 53.93 & 3.56 & 6.70 & 5.07 & 1.63 & 3.11 \\
\hline 10 & 11.56 & 7.65 & 55.47 & 3.95 & 7.11 & 4.97 & 2.13 & 2.51 \\
\hline 11 & 15.81 & 5.69 & 58.09 & 3.48 & 6.87 & 5.07 & 1.80 & 3.62 \\
\hline 12 & 13.32 & 6.46 & 54.51 & 3.48 & 7.10 & 4.67 & 2.43 & 4.83 \\
\hline 13 & 13.46 & 5.48 & 57.89 & 3.73 & 6.68 & 4.25 & 2.44 & 2.64 \\
\hline 14 & 15.77 & 5.91 & 51.33 & 3.71 & 6.96 & 4.33 & 2.63 & 2.81 \\
\hline 15 & 11.00 & 6.43 & 57.95 & 3.39 & 7.55 & 5.13 & 2.42 & 3.29 \\
\hline 16 & 11.60 & 5.28 & 55.31 & 3.50 & 6.48 & 4.38 & 2.10 & 3.00 \\
\hline 17 & 12.73 & 7.22 & 52.82 & 3.78 & 8.25 & 5.97 & 2.28 & 3.07 \\
\hline 18 & 11.71 & 5.56 & 56.55 & 3.49 & 6.38 & 5.48 & 0.90 & 3.75 \\
\hline 19 & 12.86 & 6.19 & 55.92 & 3.59 & 6.82 & 5.24 & 1.58 & 2.80 \\
\hline 20 & 12.49 & 6.36 & 56.10 & 3.69 & 7.11 & 5.07 & 2.04 & 2.69 \\
\hline 21 & 12.21 & 5.01 & 48.20 & 4.37 & 15.08 & 14.42 & 0.66 & 3.24 \\
\hline 22 & 11.76 & 4.67 & 57.55 & 3.50 & 5.72 & 4.33 & 1.39 & 2.50 \\
\hline 23 & 13.67 & 6.47 & 56.15 & 3.80 & 7.15 & 4.35 & 2.80 & 2.96 \\
\hline 24 & 12.46 & 5.36 & 59.08 & 2.99 & 6.23 & 4.06 & 2.17 & 2.44 \\
\hline Significance & $* *$ & $* *$ & $* *$ & $* *$ & $* *$ & $* *$ & $* *$ & $* *$ \\
\hline $\mathrm{LSD}^{\mathrm{a}}$ & 0.83 & 0.39 & 3.60 & 0.23 & 0.49 & 0.37 & 0.13 & 0.21 \\
\hline \multicolumn{9}{|l|}{ Quinoa } \\
\hline 25 & 14.47 & 4.38 & 52.93 & 4.14 & 7.50 & 6.39 & 1.11 & 4.68 \\
\hline 26 & 16.89 & 6.04 & 49.75 & 3.46 & 8.28 & 6.13 & 2.15 & 5.19 \\
\hline 27 & 12.48 & 5.34 & 49.71 & 4.37 & 8.71 & 6.65 & 2.07 & 5.04 \\
\hline 28 & 11.46 & 6.43 & 52.55 & 3.92 & 8.27 & 4.90 & 3.37 & 5.34 \\
\hline 29 & 12.06 & 5.29 & 53.26 & 4.58 & 7.57 & 5.32 & 2.26 & 5.40 \\
\hline 30 & 11.38 & 6.64 & 52.87 & 4.23 & 7.15 & 5.82 & 1.33 & 5.12 \\
\hline Significance & $* *$ & $* *$ & $\mathrm{NS}^{\mathrm{b}}$ & $* *$ & $*$ & $* *$ & $* *$ & NS \\
\hline $\mathrm{LSD}^{\mathrm{a}}$ & 1.18 & 0.52 & - & 0.37 & 0.72 & 0.53 & 0.20 & - \\
\hline
\end{tabular}

*Significant at the 0.05 probability level

* Significant at the 0.01 probability level

${ }^{\text {a }}$ LSD for comparison at the 0.05 probability level

${ }^{\mathrm{b}}$ Non significant at the 0.05 probability level 


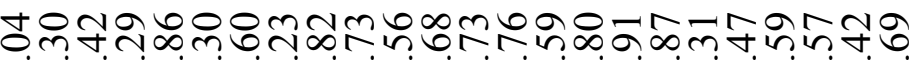

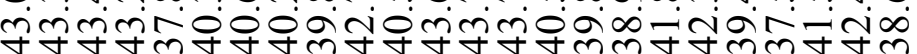

กิกี mmb omontmm m

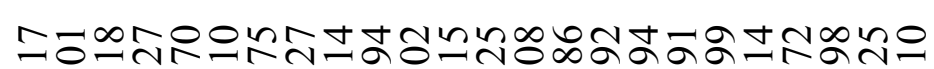

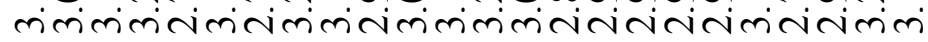

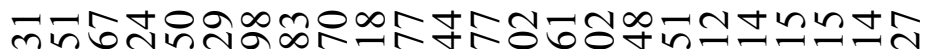

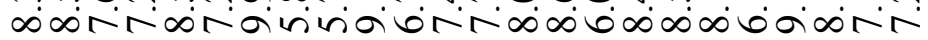

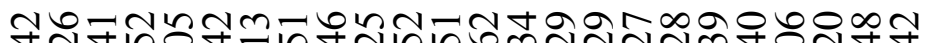

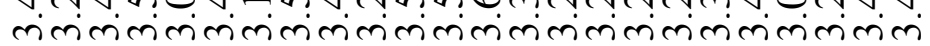

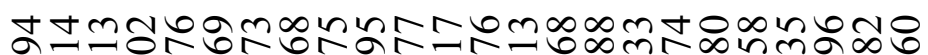

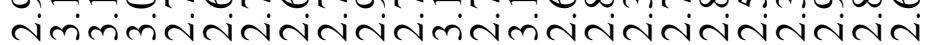

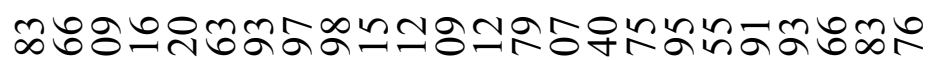

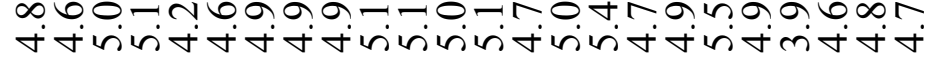

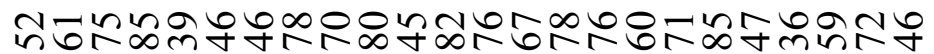

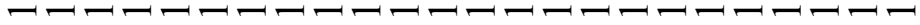

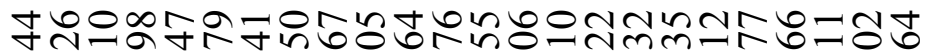

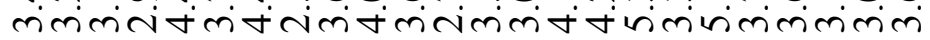

tकo융ำ

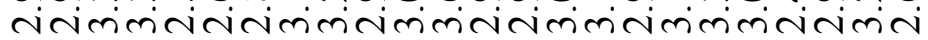

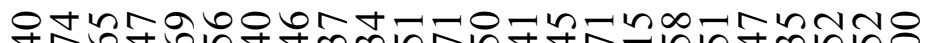

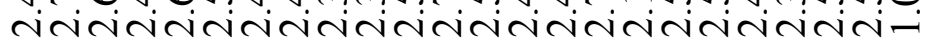

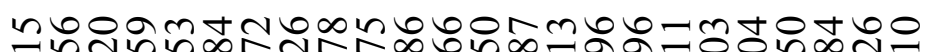

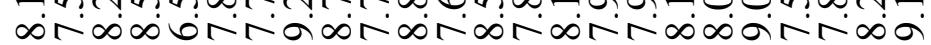

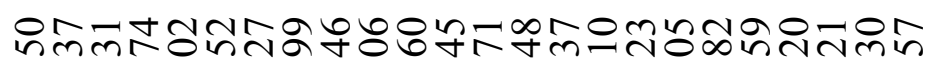

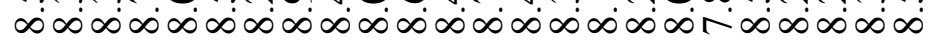

物

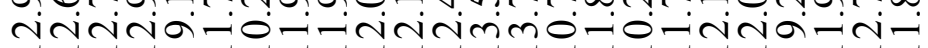

oondagantonboononnotndn

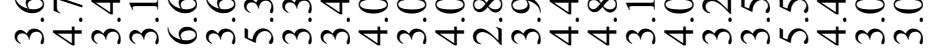

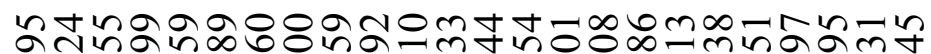

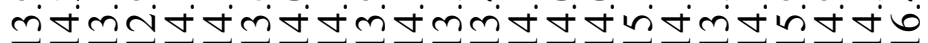

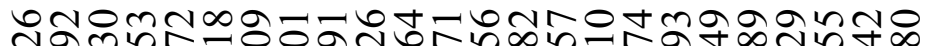

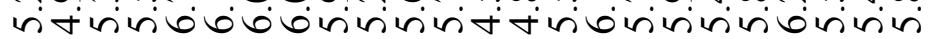

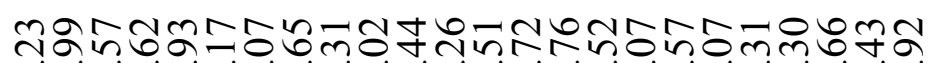

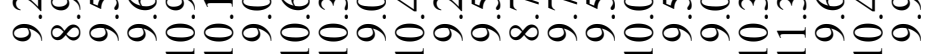
氞

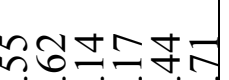

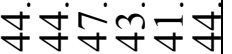

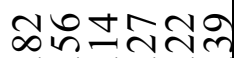

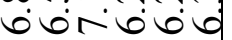

응ํำ $\forall$ riminim

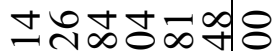
riaritod

옻ำำㅇำ

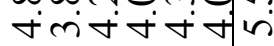

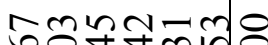
imincinain

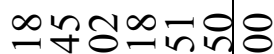

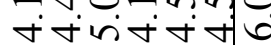
minôñoำ

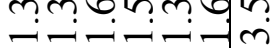

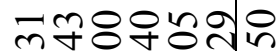
तेंiिंत्राल

앙요용 तंतिंतितन

구ำ तंतivin

๖ッণ

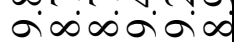
ธิ㇒㠯 웅ㅇㅇㅇ (1)

ํํ융ำ inimin

뮤ำกㅁำ तंत्रतंति moţiñ 더어프

ทคेต๗ष लंखिंन्ने

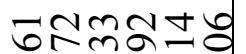
aa워 
The pattern of EAA composition in amaranth seeds was similar to that reported by Gorinstein and Moshe (1991) as well as Bejosano and Corke (1998). The amaranth seeds contained high amounts of Arg, Lys, Leu and low quantities of Met (11.87, 7.74. 5.32,

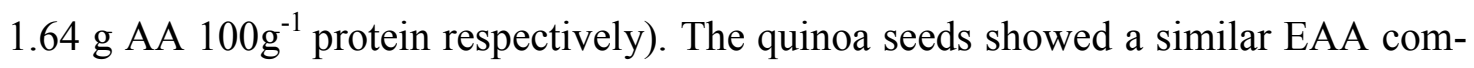
position as amaranth, but they contained higher quantities of Arg, Ala, Pro, Leu, Val and Ile. However, the values of Val, Ile, Lys, Arg were found to be higher than those reported by Ruales and Nair (1992). Therefore, the EAA contents of amaranth and qui-

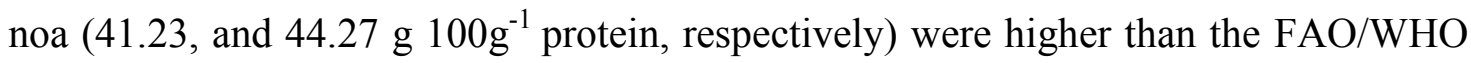

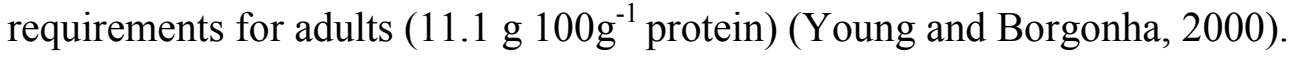

\subsubsection{Fat}

The fat content varied from 4.64 ('6') to $7.65 \% \mathrm{DM}$ ('10') in amaranth seeds, and from 4.38 ('25') to $6.64 \% \mathrm{DM}$ ('30') in quinoa seeds (Table 3.2). The values were in the same ranges as the data reported by Prakash and Pal (1992). The variation of fat content clearly depended on the species. A. cruentus had significantly higher fat content than the other species of amaranth. However, the quinoa varieties 'S407EB' showed a higher level of fat content than the 'S7' varieties.

There were significant differences in the fat content of quinoa seeds collected from Austria between the years 2001 and 2002. The quinoa varieties grown up under northern Germany conditions contained fat contents similar to that material collected from Austria in the same year of production. The level of fat content in quinoa seeds was similar to that of amaranth seeds with average values of 5.99 and $5.69 \%$ DM, respectively. However, they were lower than the results reported by Ruales and Nair in 1992. Nevertheless, the fat content of amaranth and quinoa was still higher than that of barley, rice, sorghum and wheat, which contained in each case about $1 \%$ DM (Ahamed et al., 1998).

\subsubsection{Starch}

The content of amaranth starch varied from 48.20 ('21') to $61.21 \%$ DM ('4') (Table 3.2). We found that $A$. edulis had significantly higher starch content than A. hypochondriacus. The hybrid variety 'Koniz' ('14') contained less starch than amaranth species. On the other hand, the starch contents of the samples investigated in this study were lower than that reported by Mundigler (1998). 
In quinoa seeds, the starch content ranged from 49.71 ('27') to $53.26 \% \mathrm{DM}$ ('29'). No significant differences between the quinoa varieties were observed and the results were similar to that reported by Ruales and Nair (1994). The starch contents of amaranth and quinoa (55.14 and 51.84\% DM as followed) were lower than that of 80.46 and 72.80 $\%$ DM in wheat and rye, respectively (Verwimp et al., 2004).

\subsubsection{Total Minerals}

The differences in the total mineral content between the varieties were statistically significant. The contents ranged from 2.81 (' 6 ') to $4.37 \% \mathrm{DM}$ ('21') in amaranth seeds, while they varied from 3.46 ('26') to $4.58 \% \mathrm{DM}$ ('29') in quinoa seeds. A. hypochondriacus had a significantly higher mineral content than A. cruentus and A. hybridus. The average mineral content of $3.53 \% \mathrm{DM}$ in amaranth seeds was similar to that described by Mundigler (1998). In contrast, in quinoa seeds it was with the value of 4.12 \% DM higher than those found by Ruales and Nair (1992). The mineral contents were significantly correlated with the starch and dietary fiber content $(\mathrm{r}=-0.5233$ and 0.3891 , respectively).

\subsubsection{Dietary fiber}

The TDF, IDF and SDF contents of amaranth and quinoa seeds are also presented in Table 3.2 . Among amaranth species, the range of TDF was between 5.72 ('22') and $15.08 \% \mathrm{DM}$ ('21'). The IDF content varied from 4.06 ('24') to $14.42 \% \mathrm{DM}$ ('21'). A. hypochondriacus species, the black seed variety 'Pastevny' ('5' and '21') contained significantly more TDF and IDF than the other species of amaranth in both years 2001 and 2002. For SDF, the range varied from 0.62 ('5') to $3.04 \%$ DM ('4'). A. edulis showed higher SDF than A. hypochondriacus, A. hybridus and the hybrid variety 'Koniz' ('14').

In quinoa seeds, the values of dietary fiber content ranged from 7.15 ('30') to $8.71 \%$ $\mathrm{DM}$ ('27') for TDF, from 4.90 to ('28') to $6.65 \% \mathrm{DM}$ ('27') for IDF, and from 1.11 (' 25 ') to $3.37 \% \mathrm{DM}$ ('28') for SDF. The dietary fiber content of quinoa seeds was higher than that of amaranth. However, the TDF and IDF values of quinoa seeds (7.92 and $5.83 \% \mathrm{DM}$, respectively) obtained from this study were lower than those reported by Ruales and Nair (1994). The ratio between IDF and SDF was about 3:1. The IDF was identified as the main part of the dietary fibers in the seed. This result was similar 
to that of oats (6.0 to $7.1 \%$ DM) (Manthey et al., 1999). The IDF have more positive effects to reduce the cancer risks than to reduce the blood cholesterol (Jenkins et al., 1993; Mai et al., 2003). The variety 'Pastevny' could be an attractive variety to improve the dietary fiber in healthy food products.

\subsubsection{Pentosans}

The content of pentosans in amaranth seeds varied from 2.43 (' 5 ') to $4.83 \% \mathrm{DM}$ ('12'). No significant differences between Amaranthus species were observed. The amaranth seeds contained less pentosans than quinoa seeds (3.10 and $5.13 \%$ DM, respectively). The proportion of pentosans in the amount of total dietary fiber of amaranth and quinoa seeds was $43 \%$ and $65 \%$, respectively. The proportions obtained from our study are similar to the previous results reported by Hansen et al. (2003) in rye where the dietary fiber consisted of 54 to $58 \%$ pentosans. However, the pentosans content of amaranth and quinoa was also lower than that of rye (8 to $12 \% \mathrm{DM})$.

\subsubsection{Pasting properties}

The pasting properties as important functional properties of flours during processing are shown for amaranth and quinoa in Table 4 and Figure 1. Statistical analyses of the values indicated the significant differences between the cultivars. The results showed the effects of the planting season on the pasting properties. The viscograms of amaranth and quinoa flour in comparison to that of wheat flour are presented in Figure 3.1 . The amaranth and quinoa flour had lower PT than wheat flour. The average PTs of amaranth, quinoa and wheat flour were $76.10,74.79$ and $79.00{ }^{\circ} \mathrm{C}$, respectively. Low PT of amaranth and quinoa flours could be an advantage during processing as gelatinisation process in short processing times (Zhou et al., 1998). 
Table 3.4 Pasting properties of flour from amaranth and quinoa seeds (cP)

\begin{tabular}{|c|c|c|c|c|c|c|}
\hline Code No. & $\begin{array}{l}\text { Peak } \\
\text { viscosi }\end{array}$ & Trough & Breakdown & $\begin{array}{l}\text { Final } \\
\text { viscosit }\end{array}$ & Setback & $\begin{array}{l}\text { Pasting } \\
\text { Temperature }\end{array}$ \\
\hline \multicolumn{7}{|l|}{ Amaranth } \\
\hline 1 & 1727 & 1453 & 274 & 1692 & 239 & 73.45 \\
\hline 2 & 1331 & 1231 & 100 & 1407 & 176 & 75.10 \\
\hline 3 & 1074 & 981 & 93 & 1191 & 210 & 70.20 \\
\hline 4 & 1251 & 1121 & 130 & 1281 & 160 & 72.70 \\
\hline 5 & 917 & 882 & 35 & 1180 & 298 & 89.60 \\
\hline 6 & 1381 & 1275 & 106 & 1403 & 128 & 75.85 \\
\hline 7 & 1231 & 1073 & 158 & 1236 & 163 & 73.45 \\
\hline 8 & 1604 & 1523 & 81 & 1947 & 424 & 75.05 \\
\hline 9 & 1783 & 1471 & 312 & 1716 & 245 & 75.20 \\
\hline 10 & 1082 & 977 & 105 & 1167 & 190 & 71.90 \\
\hline 11 & 1255 & 1138 & 117 & 1301 & 163 & 77.60 \\
\hline 12 & 1745 & 1487 & 258 & 1691 & 204 & 73.30 \\
\hline 13 & 1867 & 1823 & 44 & 2757 & 934 & 77.55 \\
\hline 14 & 1649 & 1485 & 164 & 1733 & 248 & 74.30 \\
\hline 15 & 1489 & 1314 & 175 & 1507 & 193 & 76.70 \\
\hline 16 & 1269 & 1096 & 173 & 1271 & 175 & 75.90 \\
\hline 17 & 1438 & 1256 & 182 & 1441 & 185 & 76.75 \\
\hline 18 & 1420 & 1166 & 254 & 1418 & 252 & 76.70 \\
\hline 19 & 1332 & 1219 & 113 & 1400 & 181 & 75.00 \\
\hline 20 & 1335 & 1172 & 163 & 1360 & 188 & 73.45 \\
\hline 21 & 1301 & 1207 & 94 & 1358 & 151 & 74.35 \\
\hline 22 & 818 & 764 & 54 & 1127 & 363 & 91.30 \\
\hline 23 & 1303 & 1139 & 164 & 1309 & 170 & 75.10 \\
\hline 24 & 1423 & 1235 & 188 & 1421 & 186 & 75.85 \\
\hline Significance & $* *$ & $* *$ & $* *$ & $* *$ & $* *$ & $* *$ \\
\hline $\mathrm{LSD}^{\mathrm{a}}$ & 54 & 47 & 15 & 70 & 33 & 0.97 \\
\hline \multicolumn{7}{|l|}{$\overline{\text { Quinoa }}$} \\
\hline 25 & 1430 & 1358 & 72 & 2172 & 814 & 83.85 \\
\hline 26 & 1496 & 1425 & 71 & 1894 & 469 & 74.35 \\
\hline 27 & 1709 & 1643 & 66 & 2355 & 712 & 74.30 \\
\hline 28 & 1613 & 1493 & 120 & 1892 & 399 & 71.80 \\
\hline 29 & 1643 & 1587 & 56 & 2228 & 641 & 73.45 \\
\hline 30 & 1755 & 1601 & 154 & 2074 & 473 & 71.00 \\
\hline Significance & $* *$ & $* *$ & $* *$ & $* *$ & $* *$ & $* *$ \\
\hline $\mathrm{LSD}^{\mathrm{a}}$ & 51 & 46 & 16 & 76 & 66 & 1.89 \\
\hline
\end{tabular}

" Significant at the 0.05 probability level

Significant at the 0.01 probability level

${ }^{a}$ LSD for comparison at the 0.05 probability level 


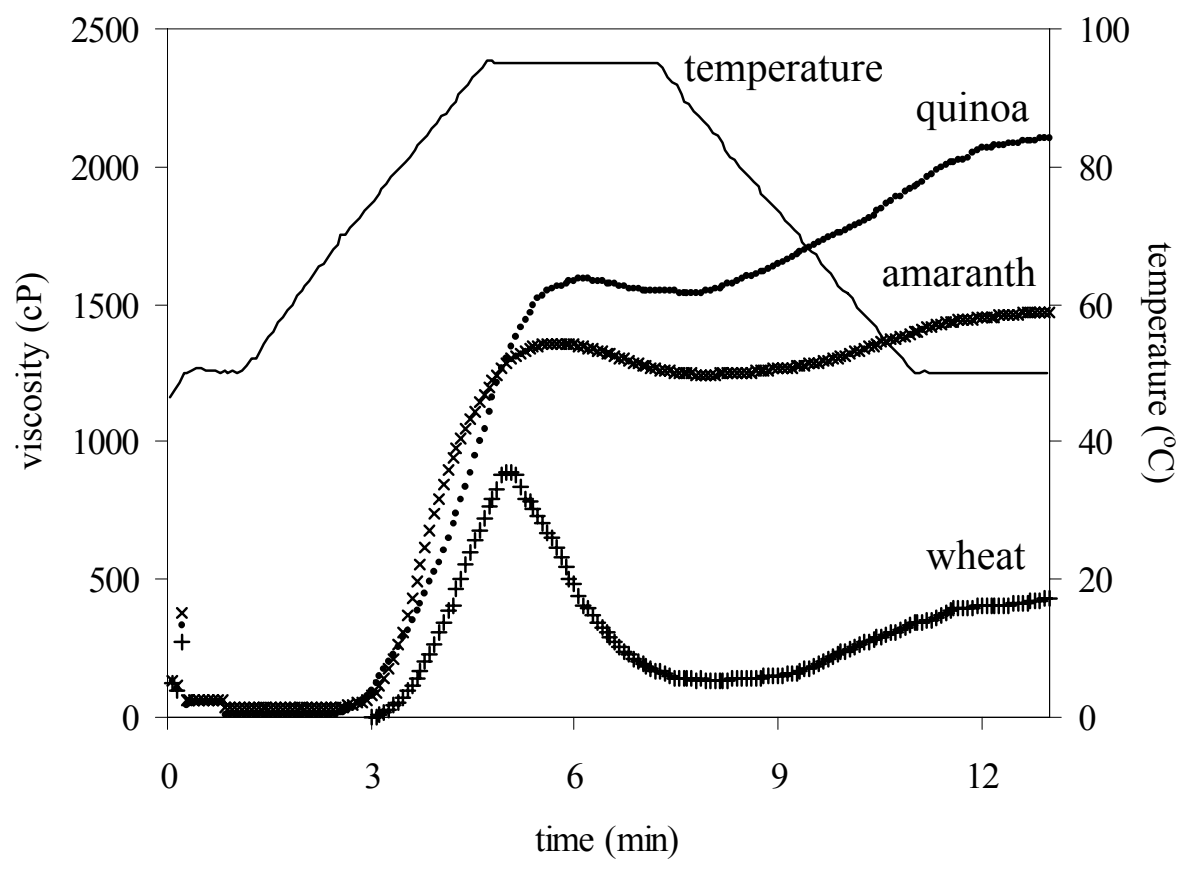

Figure 3.1 RVA viscograms of the mean values of amaranth, quinoa and wheat flour

In amaranth, the variety ' 22 ' had with $91.30{ }^{\circ} \mathrm{C}$ the highest PT. This variety showed also the lowest PV and FV (818 and $1127 \mathrm{cP}$ as followed).

After the onset of swelling, a rapid increasing in the viscosity was occurred. The quinoa and amaranth flour had a higher PV than wheat flour. This result indicated that quinoa and amaranth flour had higher water-binding capacity than wheat flour. The PV was significantly and negatively correlated with the PT. Amaranth flour was more stable than wheat and quinoa flour after the processes of swelling and cooling. Quian and Kuhn (1999) reported similar patterns in starch isolated from amaranth and quinoa.

The BD of quinoa flour was lower than that of wheat and amaranth flour, resulting in the higher final viscosity after cooling. The low SB and BD of amaranth and quinoa flour presented more stability to maintained viscosity than quinoa and wheat flour. The PT was correlated with fat and dietary fiber contents. Baldwin (2001) assumed that the 
protein and fat content on the surface of starch granules influenced the biosynthesis of the starch granule.

\subsection{Conclusions}

The variation in seed composition of amaranth and quinoa was the result of the interactions between genotype and environment. The chemical composition of the analyzed amaranth and quinoa species was affected by location and planting season. This effect could be considered for breeding programs to improve the agronomic characters for obtaining more stables line of chemical composition and content. Most of the chemical components of amaranth seeds were similar to that of quinoa. The variation of the protein content was mainly affected by the planting season. However, differences between the species were not found. The analyzed proteins were rich in lysine and its content is sufficient for the human nutritional requirement. The fat and starch contents were mainly affected by the variety. Furthermore, the starch content was correlated with the contents of total minerals, TDF and pentosans. The amaranth varieties contained higher starch and lower pentosans contents than the investigated quinoa varieties. The contents of fat and TDF were also affected by the physico-chemical properties of the seed flours. Their pasting temperatures were lower than that of wheat flour. Amaranth flour had more gel formation ability and viscosity than wheat flour. The high concentration in essential nutritional compounds showed the potency of amaranth and quinoa seeds production under northern Germany conditions.

\section{Acknowledgements}

This research project was partly supported by the Postharvest Technology Institute, Chiang Mai University, Thailand. We would gratefully acknowledge Dr. G. Sauerbeck, FAL Braunschweig, AMR, Szarlat and ZENO companies for supporting the seed materials. 


\subsection{References}

Anonymous. 1998. Applications manual for the Rapid Visco ${ }^{\mathrm{TM}}$ Analyzer. Newport Scientific, Warriewood, Australia.

Ahamed, N.T., Singhal, R.S., Kulkarni, P.R., Pal, M. 1998. A lesser-known grain, Chenopodium quinoa: Review of the chemical composition of its edible parts. Food and Nutr. Bull. 19, 61-70.

AOAC. 1984. Official Methods of Analysis, 14th edition, S. Williams (ed.). Assoc. Official Analytical Chemists, Arlington, VA.

Asp, N.G., Johansson, C.G., Hallmer, H., Siljestrom, M. 1983. Rapid enzymatic assay of insoluble and soluble dietary fiber. J. Agric. Food Chem. 31,476-482.

Aufhammer, W., Kaul, H.P., Herz, P., Nalborezyk, E., Dalbiak, A., Gontarczyk M. 1995. Grain yield formation and nitrogen uptake of amaranth. Eur. J. Agron. 4, 379386.

Baldwin, P.M. 2001. Starch granule-associated proteins and polypeptides: a review. Starch/Stärke 53, 475-503.

Bejosano, F.P., Corke, H. 1998. Protein quality evaluation of Amaranthus wholemeal flours and protein concentrates. J. Sci. Food Agric. 76, 100-106.

Bressani, R., González, J.M., Zúñiga, J., Breuner, M., Elías, L.G. 1987. Yield, selected chemical composition and nutritive value of 14 selections of amaranth grain representing four species. J. Sci. Food Agric. 38, 347-356

Brinegar, C. 1997. The seed storage proteins of quinoa. In: Damodaran S.(Ed.). Food proteins and lipids. Plenum Press, New York, pp. 109-115.

Cohen, S.A., Michaud, D.P. 1993. Synthesis of a fluorescent derivatizing reagent, 6aminoquinolyl- $N$-hydroxysuccinimidyl carbamate, and its application for the analysis of hydrolysate amino acids via high-performance liquid chromatography. Anal. Biochem. 211, 279-287.

Dörfer, J. 1999. Zur Analytik von Pentosanen (Arabinoxylanen) in Getreideprodukten. Lebensmittelchemie 53, 99-100.

Gorinstein, S., Moshe, R. 1991. Evaluation of four Amaranthus species through protein electrophoretic patterns and their amino acid composition. J. Agric. Food Chem. 39, 851-854.

Gorinstein, S., Pawelzik, E., Delgado-Licon, E., Haruenkit, R., Weisz, M., Trakhtenberg, S. 2002. Characterization of pseudocereal and cereal proteins by protein and amino acid analyses. J. Sci. Food Agri. 82, 886-891.

Hansen, H.B., Rasmussen, C.V., Bach Knudsen, K.E., Hansen, A. 2003. Effects of genotype and harvest year on contents and composition of dietary fibre in rye (Secale cereale L) grain. J. Sci. Food Agri. 83, 76-85.

ICC Standards. 1999. Standard methods of the International Association for Cereal Science and Technology (ICC). International Association for Cereal Science and Technology, Vienna, Austria.

Jacobsen, S.E., Jørgensen, I., Stølen, O. 1992. Cultivation of quinoa (Chenopodium quinoa) under temperate climatic conditions in Denmark. J. Agric. Sci. 122, 47-52.

Jauregui, R.N.C., Silva, M.E.M.P., Areas, J.A.G. 2000. Extrusion cooking process for amaranth (Amaranthus caudatus L.). J. Food Sci. 65, 1009-1015.

Jenkins, D., Wolever, T., Rao, A.V., Hegele, R.A., Mitchell, S.J., Ransom, T., Boctor, D.L., Spadafora, P.J., Jenkins, A.L., Mehling, C., Relle, L.K., Connelly, P.W., Story, J.A., Furumoto, E.J., Corey, P., Wursch, P. 1993. Effect on blood lipids of very high 
intakes of fiber in diets low in saturated fat and cholesterol. N. Engl. J. Med. 329, 2126.

León-Camacho, M., García-González, D.L., Aparicio, R. 2001. A detailed and comprehensive study of amaranth (Amaranthus cruentus L.) oil fatty profile. Eur. Food Res. Technol. 213, 349-355.

Mai, V., Flood, A., Peters, U., Lacey, J.V. Jr., Schairer, C., Schatzkin, A. 2003. Dietary fibre and risk of colorectal cancer in the Breast Cancer Detection Demonstration Project (BCDDP) follow-up cohort. Int. J. Epidemiol. 32, 234-239

Manthey, F.A., Hareland, G.A., Huseby, D.J. 1999. Soluble and insoluble dietary fiber contents and composition in oat. Cereal Chem. 76, 417-420.

Mundigler, N. 1998. Isolation and determination of starch from amaranth (Amaranthus cruentus) and quinoa (Chendopodium quinoa). Starch/Stärke 50, 67-69.

Prakash, D., Pal, M. 1992. Seed protein, fat and fatty acid profile of Amaranthus species. J. Sci. Food Agri. 58, 145-147.

Prakash, D., Joshi, B.D., Pal, M. 1995. Vitamin C in leaves and seed oil composition of the Amaranthus species. Inter J. Food Sci. and Nutr. 46, 47-51.

Quian, J., Kuhn, M. 1999. Characterization of Amaranthus cruentus and Chenopodium quinoa starch, Starch/Stärke 51, 116-120.

Risi, J., Galwey, N.W. 1991. Genotype x environment interaction in the Andean grain crop quinoa (Chenopodium quinoa) in temperate environments. Plant breeding. 107, 141-147.

Ruales, J., Nair, B.M. 1992. Nutritional quality of the protein in quinoa (Chenopodium quinoa willd) seeds. Plant Food Hum. Nutr. 42, 1-11.

Ruales, J., Nair, B.M. 1993. Contents of fat, vitamins and minerals in quinoa (Chenopodium quinoa willd.) seed. Food Chem. 48, 131-137.

Ruales, J., Nair, B.M. 1994. Properties of starch and dietary fibre in raw and processed quinoa (Chenopodium quinoa willd) seeds. Plant Food Hum. Nutr. 45, 223-246.

Sauerbeck, G., Stolzenburg, K., Schweiger, P., Schroeter, C., Wilhelm, E., Matthäus, B. 2002. Anbau von Amaranth und Quinoa in Norddeutschland: Kornqualität am Beispiel von Fettuntersuchungen. Getreide, Mehl und Brot 56, 330-333.

Singhal, R., Kulkarni, P.R. 1988. Composition of the seeds of some Amaranthus species. J. Sci. Food Agri. 42, 325-331.

Sweeney, R. A., Rexroad, P. R. 1987. Comparison of LECO FP-228 "Nitrogen Determination" with AOAC copper analyst Kjeldahl method for crude protein. J. AOAC International 70, 1028-1030.

USDA. 2003. Amaranth. Food Group 20 Cereal Grains and Pasta. USDA Nutrient Database for Standard Reference, Release 16. pp 1-2.

Verwimp, T., Vandeputte, G.E., Marrant, K., Delcour, J.A. 2004. Isolation and characterisation of rye starch. J. Cereal Sci. 39, 85-90.

Wood, S. G., Lawson, L. D., Fairbanks, D. J., Robinson, L. R., Anderson, W. R. 1993. Seed lipid content and fatty acid composition of three quinoa cultivars. J. Food Comp. and Anal. 6, 41-44.

Young, V.R., Borgonha, S. 2000. Nitrogen and amino acid requirements: the Massachusetts institute of technology amino acid requirement pattern. J. Nutr. 130, 1841S1849S.

Zheleznov, A.V., Solonenko, L.P., Zheleznova, N.B. 1997. Seed proteins of the wild and the cultivated Amaranthus species. Euphytica 97, 177-182.

Zhou, M.X., Roberts, G.L., Robards, K., Glennie-Holmes, M. 1998. Effects of sowing date, nitrogen application and sowing rate on oat quality. Aust J Agri Res 49, 845-852. 


\section{Yield and Nitrogen Assimilation of Amaranth (Amaranthus spp.) and Quinoa (Cheno- podium quinoa Willd)}

\section{Abstract}

Amaranth (Amaranthus spp.) and quinoa (Chenopodium quinoa Willd) are pseudocereals containing protein-rich seeds which have a better balance in amino acid composition than that of wheat and barley. The effects of nitrogen fertilizer on nitrogen uptake and its assimilation from soil to the vegetative and grain parts are still rarely analyzed. In the present study, two varieties of amaranth and quinoa were grown in pots and supplied with $0,0.8$ and $1.2 \mathrm{~g} \mathrm{~N}$ pot $^{-}$

1 . Plant height, grain weight, biomass and grain increased with rising nitrogen supply. Harvest indexes were 0.28 and 0.33 in amaranth, and 0.19 and 0.21 in quinoa, respectively. Nitrogen accumulation in plant and grain responded to the nitrogen fertilizer application. Nitrogen use efficiency (NUE) varied from 13.78 to $21.64 \mathrm{~g}_{\text {grain }} \mathrm{g}^{-1} \mathrm{~N}_{\min }$. While the rate of nitrogen fertilizer application increased, nitrogen utilization efficiency (NUtE) and NUE decreased. NUtE was observed as a limiting factor in nitrogen use efficiency at $1.2 \mathrm{~g} \mathrm{~N} \mathrm{pot}^{-1}$. It was found that quinoa had higher yield and NUE than amaranth. Nitrogen harvest index (NHI) amounted to 0.35 in amaranth, and 0.54 in quinoa. The grain produced per unit of grain nitrogen (GNE) was significantly and negatively correlated with the nitrogen fertilizer application. The nitrogen uptake efficiency (NUpE) should be also considered for quinoa improvement.

Key words: amaranth - quinoa - yield - nitrogen use efficiency

\subsection{Introduction}

Amaranth (Amaranthus spp.) and quinoa (Chenopodium quinoa Willd) are protein-rich pseudocereals. These cultivated plants have a long and varied record of uses. They were and remain as an importance component in the diet of South America. Their seeds have also a better balance in their amino acid composition than the major cereal seeds. They are used also for the production of healthy food in several world regions (National Research Council, 1989). Amaranth species produce 720 to $1320 \mathrm{~g} \mathrm{~m}^{-2}$ total biomass and obtain 140 to $300 \mathrm{~g} \mathrm{~m}^{-2}$ grain, while quinoa produce 238 to $636 \mathrm{~g} \mathrm{~m}^{-2}$ total biomass and contain 215 to $294 \mathrm{~g} \mathrm{~m}^{-2}$ grain. The harvest indexes (HI) range from 0.2 to 0.3 in amaranth and from 0.2 to 0.5 in qui- 
noa (Aufhammer et al. 1995, Spehar et al. 1998). The fertilizer use efficiency is an important factor due to the cost of production and various environmental effects. Nitrogen is the primary limiting nutrient for grain production. Availability and supply of nitrogen vary between species depending on their requirements (Sinclair and de Wit, 1975). Plants are different in nitrogen use efficiency upon each levels of nitrogen supply, which was also reported among genotypes by Moll et al. (1982). Wyss et al. (1991) showed as well that genetic differences in assimilation uptake and remobilization by source and utilization efficiencies of sink had profound effects in the seed especially on its protein concentration. Elbehri et al. (1993) reported that amaranth grain yield was responded to nitrogen fertilizer in most of the environments and caused increased lodging of the plants. Kaul et al. (1996) found that the nitrogen uptake and the amount of the nitrogen residues were correlated with the dry matter production. Myers (1998) also described that with rising nitrogen fertilization up to $180 \mathrm{~N} \mathrm{ha}^{-1}$, the yield was increased by $43 \%$. These findings are in contrasts with results of Bressani et al. (1987), who reported that the yield of amaranth was not significantly affected by increased fertilizer rate. At temperate latitudes, the quinoa grain yields were strongly dependent on the variety (Risi and Galwey, 1991). In amaranth, effects of environmental conditions on yield have been described. The semidwarf cultivar 'K432' produced low grain yield in the dry environments and the highest grain yield under cool and moist conditions (Henderson et al., 2000).

Recently, pseudocereals are of interest for the commercial production in several European countries (Jacobsen et al., 1994; Jacobsen, 1997; Aufhammer et al., 1995). However, the nitrogen efficiency in amaranth and quinoa production under Western European climatic conditions is still not sufficient understood. The aim of this study was, therefore, to investigate the effect of nitrogen fertilizer on biomass, grain yields, nitrogen uptake and its assimilation from the soil to the vegetative and grain parts of amaranth and quinoa.

\subsection{Materials and Methods}

\subsubsection{Plant materials}

This experiment was carried out in 2001 and 2002 at the Institute of Agricultural Chemistry, Georg-August University of Goettingen. Split-plot in completely randomized design (CRD) with three replications was used. Main plots were cultivars, sub plots were the nitrogen levels. Two of each amaranth varieties [Bärnkraft (A. cruentus) and K432 (A. hypochondriacus x A. hybridus)] and quinoa (Faro and Tango) were cultivated in pots. Each pot contained $5 \mathrm{~kg}$ of 
dried sandy loam soil with mineral nitrogen content in the soil of $0.21 \mathrm{~g} \mathrm{pot}^{-1}$. Two plants were grown in every pot and applied with three treatments of $\mathrm{NH}_{4} \mathrm{NO}_{3}$ fertilizer $(0,0.8$ and $1.2 \mathrm{~g} \mathrm{~N} \operatorname{pot}^{-1}$ ). Pre-planting fertilizer was used at the rates of $0,0.8$ and $0.8 \mathrm{~g} \mathrm{~N} \operatorname{pot}^{-1}$, respectively. To reach $1.2 \mathrm{~g} \mathrm{~N} \operatorname{pot}^{-1}$, top dressing nitrogen fertilizer as $0.4 \mathrm{~g} \mathrm{~N}_{\text {pot }}{ }^{-1}$ was added to one of the $0.8 \mathrm{~g} \mathrm{~N}$ pot $^{-1}$ treatment at the flowering stage. Phosphorus and potassium supply was used as 0.6 and $0.8 \mathrm{~g} \mathrm{pot}^{-1}$, respectively (adjusted with $\mathrm{CaHPO}_{4}$ and $\mathrm{K}_{2} \mathrm{SO}_{4}$ ). Plant lodging was protected by using a wire frame. Weed control was handled by hands. During the grain filling period, $1 \%$ Oxydemeton-Methyl was used for insect control. For water control, plants were sprinkled with water every three days during the vegetative period and every two days during the reproductive period.

Amaranth and quinoa were sown on $7^{\text {th }}$ May in 2001, and on $9^{\text {th }}$ May in 2002. Plants were harvested after the majority of them were senescent during the period of $23^{\text {rd }}$ August to $26^{\text {th }}$ September in 2001, and $28^{\text {th }}$ August to $20^{\text {th }}$ September in 2002. Plant height, total biomass, grain weight $(\mathrm{Gw})$, thousand-kernel weight and nitrogen content in biomass and grain were determined. Weight measurement was adjusted to $14 \%$ moisture content.

\subsubsection{Soil mineral content}

The mineral nitrogen content in the soil (soil nitrate plus amomonia) was determined in 0.01 $\mathrm{M} \mathrm{CaCl}_{2}$ extract $(1: 2.5 \mathrm{~W} / \mathrm{V})$ and analyzed by a flow injection analyzer model SFAS 5100 (Skalar, Germany) (Houba et al., 1986).

\subsubsection{Nitrogen determination}

The nitrogen determination was done by Dumas method using an automated LECO CN analyzer model CN2000 (LECO, St. Joseph, MI) (Sweeney and Rexroad, 1987).

\subsubsection{Nitrogen use efficiency}

Nitrogen use efficiency (NUE), nitrogen uptake efficiency (NUpE), nitrogen utilization efficiency (NUtE), nitrogen harvest index (NHI) and grain produced per unit of grain $\mathrm{N}$ (GNE) were determined as described by Moll et al. (1982) and Elbehri et al. (1993) and defined as:

$$
\begin{array}{ll}
\mathrm{NUE}= & \text { Gw/Ns }\left(\mathrm{g}_{\text {grain }} \mathrm{g}^{-1} \mathrm{~N}_{\text {min }}\right) \\
\mathrm{NUpE}= & \mathrm{Nt} / \mathrm{Ns}\left(\mathrm{g} \mathrm{N}_{\text {plant }} \mathrm{g}^{-1} \mathrm{~N}_{\text {min }}\right) \\
\mathrm{NUtE}= & \text { Gw/Nt }\left(\mathrm{g}_{\text {grain }} \mathrm{g}^{-1} \mathrm{~N}_{\text {plant }}\right)
\end{array}
$$




$$
\begin{array}{lll}
\mathrm{NHI} & = & \mathrm{Ng} / \mathrm{Nt}\left(\mathrm{g} \mathrm{N}_{\text {grain }} \mathrm{g}^{-1} \mathrm{~N}_{\text {plant }}\right) \\
\mathrm{GNE}= & \mathrm{Gw} / \mathrm{Ng}\left(\mathrm{g}_{\text {grain }} \mathrm{g}^{-1} \mathrm{~N}_{\text {grain }}\right)
\end{array}
$$

in which,

$$
\begin{array}{lll}
\mathrm{Gw} & = & \text { grain yield per plant }(\mathrm{g} \text { grain }) \\
\mathrm{Ng} & = & \text { nitrogen accumulated in the grain at harvest per plant }\left(\mathrm{g} \mathrm{N}_{\text {grain }}\right) \\
\mathrm{Ns} & = & \text { total } \mathrm{N} \text { supply per plant }(\text { mineral fertilizer plus mineral soil } \mathrm{N})\left(\mathrm{g} \mathrm{N}_{\text {min }}\right) \\
\mathrm{Nt} & = & \text { total aboveground plant } \mathrm{N}\left(\mathrm{g} \mathrm{N}_{\text {plant }}\right)
\end{array}
$$

Analyses of variance and least significant difference (LSD) values for the comparison of cultivars and nitrogen levels were conducted according to Steel and Torry (1980). Relationships between parameters were determined by using the Pearson's simple correlation test. The $p$ values of $<0.05$ were considered as significant values. Statistical analyses were performed by using the software Statistix 7.0 (Analytical Software, Tallahassee, FL).

\subsection{Results and Discussion}

In 2001, plants were damaged by insects during growing. Only the parameters grain yield, nitrogen accumulated in grain at harvest, nitrogen use efficiency and grain yield per unit of grain nitrogen were determined (Table 4.1).

In the initial step of investigation, the growing periods of amaranth and quinoa with three different rates of nitrogen fertilizer applications were examined. Significant differences between cultivars and nitrogen levels during their growing periods were determined. The growing period of amaranth was longer than that of quinoa.

In 2001, nitrogen fertilizer application (0.8 and $\left.1.2 \mathrm{~g} \mathrm{~N} \mathrm{pot}^{-1}\right)$ decreased growing period of amaranth "Bärnkraft" variety when compared with $0 \mathrm{~g} \mathrm{~N}^{-1}$ pot $^{-1}$ treatment $(110,109$ and 147 days, respectively).

In 2002, when compared the reproductive periods of both cultivars, it was found that the amaranth variety "Bärnkraft" and the quinoa variety "Faro" had longer reproductive periods than the other two cultivars. The quinoa variety "Tango" without nitrogen fertilizer application (0 $\mathrm{g} \mathrm{N}$ pot $^{-1}$ ) had a longer growing period than the other with the other two nitrogen treatments (115, 107 and 107 days, respectively).

Plant height was measured at the maturity stage. Quinoa had significantly higher plant height than amaranth and the differences between varieties in each species were also significant (Ta- 
ble 4.2). The $0.8 \mathrm{~g} \mathrm{~N} \mathrm{pot}^{-1}$ treatment caused the highest plant height compared with the other nitrogen treatments $(114.5,81.2$ and $111.2 \mathrm{~cm}$, respectively). These results are in contrast with the previous results reported by Elbehri et al. (1993), in which plant height was continuously increased with increased nitrogen fertilizer rates. Myers (1998) found also that under optimum soil conditions, plant height and yield of amaranth increased. But at high rates of nitrogen fertilizer, grain yield was decreased caused by plant lodging. However, in this experiment lodging percentage was not recorded because a wire frame was used for protecting against the risk of lodging.

Table 4.1: Grain yield, nitrogen accumulated in grain at harvest, nitrogen use efficiency and grain yield per unit of grain nitrogen of amaranth and quinoa applied with three different rates of nitrogen fertilizer in 2001

$\left[\mathrm{Ng}=\right.$ nitrogen accumulated in grain at harvest $\left(\mathrm{g} \mathrm{N}_{\text {grain }}\right), \mathrm{NUE}=$ Nitrogen use efficiency $(\mathrm{g}$ grain $\left.\mathrm{g}^{-1} \mathrm{~N}_{\min }\right)$, GNE = grain produced per unit of grain nitrogen $\left(g\right.$ grain $\left.\mathrm{g}^{-1} \mathrm{~N}_{\text {grain }}\right)$ ]

\begin{tabular}{llcccc}
\hline $\begin{array}{l}\text { Plants } \\
\text { Species }\end{array}$ & Varieties & $\begin{array}{c}\text { Grain yield } \\
\left(\text { g plant }^{-1}\right)\end{array}$ & $\mathrm{Ng}$ & $\mathrm{NUE}$ & GNE \\
\hline Amaranth & Bärnkraft & 2.46 & 0.06 & 10.53 & 41.70 \\
& K432 & 2.94 & 0.08 & 10.97 & 38.32 \\
Quinoa & Faro & 2.50 & 0.06 & 10.87 & 40.64 \\
& Tango & 5.70 & 0.13 & 20.99 & 45.45 \\
\hline Significant & & $* *$ & $* *$ & $* *$ & $* *$ \\
LSD & & 0.257 & 0.007 & 0.978 & 1.181 \\
\hline
\end{tabular}

Nitrogen levels $\left(\mathrm{g} \mathrm{N} \text { pot }^{-1}\right)^{\mathrm{b}}$

\begin{tabular}{ccccc}
\hline 0 & 2.72 & 0.05 & 27.18 & 50.14 \\
0.8 & 3.75 & 0.10 & 7.50 & 38.20 \\
1.2 & 3.74 & 0.10 & 5.34 & 36.25 \\
\hline Significant & $* *$ & $* *$ & $* *$ & $* *$ \\
LSD $^{\text {a }}$ & 0.223 & 0.006 & 0.847 & 1.023 \\
\hline
\end{tabular}

\footnotetext{
Significant at the 0.05 probability level

Significant at the 0.01 probability level

${ }^{\text {a }}$ LSD for comparison at the 0.05 probability level

${ }^{\mathrm{b}}$ Average of all plant species and cultivars
} 
Amaranth "Bärnkraft" variety produced significantly higher biomass than the other cultivars. The biomass increased significantly in correlation with the rates of nitrogen fertilizer from $8.97 \mathrm{~g} \mathrm{plant}^{-1}$ for the treatment without nitrogen fertilizer, to 30.87 and $35.17 \mathrm{~g} \mathrm{plant}^{-1}$ for the treatments with 0.8 and $1.2 \mathrm{~g} \mathrm{~N}^{-1}$, respectively (Table 4.2). This result is in agreement with Elbehri et al. (1993). They reported that biomass increased from 10.2 to $12.8 \mathrm{Mg} \mathrm{ha}^{-1}$ when applied 0 and $180 \mathrm{~kg} \mathrm{~N} \mathrm{ha}^{-1}$ in amaranth.

Table 4.2: Agronomic characteristics, biomass, grain yield, harvest index (HI), nitrogen accumulated in grain at harvest, total aboveground plant nitrogen of amaranth and quinoa applied with three different rates of nitrogen fertilizer in 2002

$[\mathrm{TKW}=$ Thousand-Kernel Weight, $\mathrm{Ng}=$ nitrogen accumulated in grain at harvest per plant $(\mathrm{g}$ $\left.\mathrm{N}_{\text {grain }}\right), \mathrm{Nt}=$ total aboveground plant nitrogen $\left(\mathrm{g} \mathrm{N}_{\text {plant }}\right)$ ]

\begin{tabular}{|c|c|c|c|c|c|c|c|c|}
\hline $\begin{array}{l}\text { Plants } \\
\text { Species }\end{array}$ & Varieties & $\begin{array}{c}\text { Plant height } \\
\text { (cm) }\end{array}$ & $\begin{array}{l}\text { Biomass } \\
\left(\text { g plant }^{-1}\right)\end{array}$ & $\begin{array}{c}\text { Grain } \\
\text { yield } \\
\text { (g plant }^{-1} \text { ) }\end{array}$ & $\begin{array}{c}\text { TKW } \\
\text { (g) }\end{array}$ & HI & $\mathbf{N g}$ & $\mathbf{N t}$ \\
\hline \multirow[t]{2}{*}{ Amaranth } & Bärnkraft & 95 & 27.92 & 5.78 & 0.76 & 0.21 & 0.12 & 0.42 \\
\hline & K432 & 73 & 22.91 & 4.39 & 0.60 & 0.19 & 0.10 & 0.33 \\
\hline \multirow[t]{2}{*}{ Quinoa } & Faro & 128 & 23.50 & 6.91 & 2.54 & 0.29 & 0.15 & 0.31 \\
\hline & Tango & 113 & 25.69 & 9.08 & 2.83 & 0.34 & 0.19 & 0.36 \\
\hline Significant & & $* *$ & $* *$ & $* *$ & $* *$ & $* *$ & $* *$ & $* *$ \\
\hline $\mathrm{LSD}^{\mathrm{a}}$ & & 5.1 & 1.674 & 0.466 & 0.679 & 0.010 & 0.014 & 0.041 \\
\hline
\end{tabular}

Nitrogen levels $\left(\mathrm{g} \mathrm{N} \mathrm{pot}^{-1}\right)^{\mathrm{b}}$

\begin{tabular}{cccccccc}
\hline 0 & 81 & 8.97 & 2.16 & 1.58 & 0.24 & 0.04 & 0.07 \\
0.8 & 114 & 30.87 & 7.81 & 1.77 & 0.26 & 0.16 & 0.39 \\
1.2 & 111 & 35.17 & 9.65 & 1.70 & 0.27 & 0.23 & 0.60 \\
\hline Significant & $* *$ & $* *$ & $* *$ & $* *$ & $* *$ & $* *$ & $* *$ \\
LSD $^{\mathrm{a}}$ & 4.4 & 1.450 & 0.404 & 0.059 & 0.009 & 0.012 & 0.035 \\
\hline
\end{tabular}

\footnotetext{
"Significant at the 0.05 probability level

Significant at the 0.01 probability level

${ }^{a}$ LSD for comparison at the 0.05 probability level

${ }^{\mathrm{b}}$ Average of all plant species and cultivars
} 
In 2001, the grain yield was affected by insect damage and resulted in lower yield when compared with the year 2002. However, in 2002 we found that the grain yields of quinoa were higher than that of amaranth and significantly increased when applied with the nitrogen fertilizer.

In this experiment, quinoa cultivar "Tango" produced the highest grain yield (5.70 and $9.04 \mathrm{~g}$ plant $^{-1}$ in 2001 and 2002, respectively). The treatments of 0.8 and $1.2 \mathrm{~g} \mathrm{~N} \mathrm{pot}^{-1}$ increased the yields about 138 and $138 \%$ in 2001 and 362 and $447 \%$ in 2002, respectively, compared to the treatment without nitrogen supply. This result is in accordance with Elbehri et al. (1993) and Myers (1998) for amaranth and Jacobsen et al. (1994) for quinoa. However, yields in 2001 were probably impaired because of insect damage during the grain filling period.

The grain weights of quinoa samples were significantly higher than that of amaranth. The thousand-kernel weight with $1.77 \mathrm{~g}$ was the highest after application of $0.8 \mathrm{~g} \mathrm{~N} \mathrm{pot}^{-1}$. With increasing nitrogen level to $1.2 \mathrm{~g} \mathrm{~N} \mathrm{pot}^{-1}$ it was decreased to $1.58 \mathrm{~g}$. This effect was also reported for oats (Chalmers et al., 1998). In contrast, another study showed that increased yield after nitrogen fertilizer application resulted from an increased number of seeds per plant and not from the seed weight which was not changed (Myers, 1998).

Quinoa varieties showed higher HI than amaranth. The variety "Tango" had the highest HI (0.34) from all cultivars (Table 4.2). It was increased from 0.24 to 0.26 and 0.27 when applied with $0,0.8$ and $1.2 \mathrm{~g} \mathrm{~N}$ pot $^{-1}$, respectively. In contrast, Elbehri et al. (1993) described in their studies that the HI was not affected by nitrogen fertilizer rates, probably because of the use of domesticated species.

The total aboveground plant nitrogen $(\mathrm{Nt})$ was significantly different between the cultivars (Table 2) and was at highest in amaranth "Bärnkraft" (0.42 $\left.\mathrm{g} \mathrm{N}_{\text {plant }}\right)$. It was highly significant increased after nitrogen application $\left(0.07,0.39\right.$ and $0.60 \mathrm{~g} \mathrm{~N}_{\text {plant }}$, respectively). Elbehri et al. (1993) reported also that grain and plant nitrogen concentration was linearly increased along with the rates of nitrogen fertilizer application.

The nitrogen accumulated in grain $(\mathrm{Ng})$ correlated in the same direction as $\mathrm{Nt}$ with the rates of nitrogen fertilizer. Quinoa "Tango" variety had higher $\mathrm{Ng}$ than the other cultivars in 2001 (Table 1). The $\mathrm{Ng}$ increased significantly with increasing rates of nitrogen fertilizer application from 0.05 to $0.10 \mathrm{~g} \mathrm{~N}_{\text {grain }}$.

In 2002, quinoa contained higher $\mathrm{Ng}$ than amaranth. The $\mathrm{Ng}$ of the quinoa varieties "Faro" and "Tango" amounted to 0.15 and $0.19 \mathrm{~g} \mathrm{~N}_{\text {grain }}$, respectively, whereas the amaranth varieties "Bärnkraft" and "K432" contained 0.12 and $0.10 \mathrm{~g} \mathrm{~N}$ grain. The $\mathrm{Ng}$ increased also significantly 
from 0.04 to 0.16 and $0.23 \mathrm{~g} \mathrm{~N}_{\text {grain }}$ with increasing nitrogen rates. Hayati et al. (1996) reported that the nitrogen accumulation and concentration in soybean seed increased proportionally to the nitrogen concentration in the media under in vitro culture conditions. Similarly, Noulas et al. (2004) reported that in wheat increased biomass, grain yield and grain nitrogen concentration was caused by nitrogen fertilization.

The NUE of quinoa "Tango" variety was higher than that of the other cultivars (Table 1). The NUE was significantly decreased when applied with 0.8 and $1.2 \mathrm{~g} \mathrm{~N} \mathrm{pot}^{-1}$ nitrogen fertilizer in

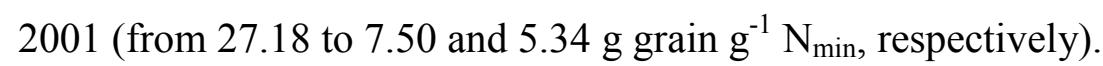

Table 4.3: Nitrogen use efficiency and components of nitrogen efficiency of amaranth and quinoa applied with three rates of nitrogen fertilizer in 2002

$\left[\mathrm{NUE}=\right.$ Nitrogen use efficiency $\left(\mathrm{g}\right.$ grain $\left.\mathrm{g}^{-1} \mathrm{~N}_{\min }\right), \mathrm{NUpE}=$ nitrogen uptake efficiency $(\mathrm{g}$ $\left.\mathrm{N}_{\text {plant }} \mathrm{g}^{-1} \mathrm{~N}_{\text {min }}\right)$, NUtE = nitrogen utilization efficiency $\left(g\right.$ grain $\left.\mathrm{g}^{-1} \mathrm{~N}_{\text {plant }}\right)$, NHI = nitrogen harvest index $\left(\mathrm{g} \mathrm{N}_{\text {grain }} \mathrm{g}^{-1} \mathrm{~N}_{\text {plant }}\right)$, GNE = grain produced per unit of grain nitrogen ( $g$ grain $\mathrm{g}^{-1}$ $\left.\mathrm{N}_{\text {grain }}\right)$ ]

\begin{tabular}{llccccc}
\hline $\begin{array}{l}\text { Plant } \\
\text { Species }\end{array}$ & Varieties & NUE & NUpE & NUtE & NHI & GNE \\
\hline Amaranth & Bärnkraft & 13.84 & 0.85 & 17.52 & 0.35 & 50.17 \\
& K432 & 12.71 & 0.77 & 16.50 & 0.35 & 46.22 \\
Quinoa & Faro & 18.31 & 0.67 & 28.24 & 0.56 & 49.74 \\
& Tango & 23.20 & 0.80 & 29.49 & 0.53 & 55.87 \\
\hline Significant & & $* *$ & $* *$ & $* *$ & $* *$ & $* *$ \\
LSD & & 1.229 & 0.085 & 1.295 & 0.028 & 2.58 \\
\hline
\end{tabular}

Nitrogen levels $\left(\mathrm{g} \mathrm{N} \text { pot }^{-1}\right)^{\mathrm{b}}$

\begin{tabular}{cccccc}
\hline 0 & 21.64 & 0.67 & 32.20 & 0.53 & 60.83 \\
0.8 & 15.63 & 0.79 & 20.55 & 0.43 & 48.46 \\
1.2 & 13.78 & 0.86 & 16.06 & 0.38 & 42.21 \\
\hline $\begin{array}{l}\text { Significant } \\
\text { LSD }^{\mathrm{a}}\end{array}$ & $* *$ & $* *$ & $* *$ & $* *$ & $* *$ \\
\hline
\end{tabular}

\footnotetext{
"Significant at the 0.05 probability level

** Significant at the 0.01 probability level

${ }^{\mathrm{a}} \mathrm{LSD}$ for comparison at the 0.05 probability level

${ }^{\mathrm{b}}$ Average of all plant species and cultivars
} 
In 2002, the NUE of quinoa was higher than that of amaranth (Table 4.2). This result was in contrast with the previous results reported by Sage and Pearcy (1987), which showed that the NUE of Amaranthus retroflexus is greater than that of Chenpodium album at high rates of nitrogen supply. Quinoa "Tango" showed significantly a higher NUE than quinoa "Faro" (23.20

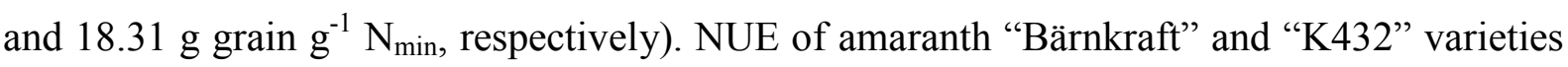
were 13.84 and $12.71 \mathrm{~g}_{\text {grain }} \mathrm{g}^{-1} \mathrm{~N}_{\text {min }}$, respectively. These values were higher than ranged from 3.5 to $7.9 \mathrm{~g}$ grain $\mathrm{g} \mathrm{N}_{\min }$ in the previous data reported by Elbehri et al. (1993). They concluded that the lower NUE was caused by the low HI (ranged from 9.9 to 15.9). However, the NUE was significantly decreased with increasing level of nitrogen fertilizer. This result showed that all plants have a reduced efficiency of nitrogen utilization when increasing rates of nitrogen fertilizer are applied.

Amaranth "Bärnkraft" had significantly higher NUpE than the other cultivars. Increased nitrogen fertilizer application led to significant increased values of NUpE. The high values of NUpE were correlated with the high values of Nt. When the level of nitrogen fertilizer application was increased from 0.8 to $1.2 \mathrm{~g} \mathrm{~N} \mathrm{pot}^{-1}$, the $\mathrm{NUpE}$ was not significantly increased.

Quinoa varieties had significantly higher NUtE than amaranth (28.86 and $17.01 \mathrm{~g}_{\text {grain }} \mathrm{g}^{-1}$ $\mathrm{N}_{\text {plant}}$, respectively), demonstrating that quinoa had a higher efficiency in producing grain per unit of plant nitrogen than amaranth. However, the NUtE was significantly decreased with increased rates of nitrogen fertilizer application. NUtE was decreased to 36 and $50 \%$ after application of 0.8 and $1.2 \mathrm{~g} \mathrm{~N}^{-1}$, respectively.

For NHI, quinoa also had significantly higher values than amaranth $\left(0.54\right.$ and $0.35 \mathrm{~g} \mathrm{~N}_{\text {grain }} \mathrm{g}^{-1}$ $\mathrm{N}_{\text {plant }}$, respectively). The NHI of amaranth was in accordance with the previous results reported by Aufhammer et al. (1995). However, the NHI values of amaranth and quinoa were observed as low values when compared with wheat ( 0.69 to $0.84 \mathrm{~g} \mathrm{~N}_{\text {grain }} \mathrm{g}^{-1} \mathrm{~N}_{\text {plant }}$ ) (Noulas et al., 2004). The NHI values were significantly decreased when applied 0.8 and $1.2 \mathrm{~g} \mathrm{~N}$ pot $^{-1}$ fertilizers (19 and $28 \%$, respectively). This result showed that quinoa had higher nitrogen translocation efficiency from source to sink organ than amaranth. Salado-Navarro et al. (1985) found that increase of NHI indicated the high rate of nitrogen partitioning to seed. This efficiency was decreased when increasing the amount of nitrogen supply. It was also reported, that NHI in oats was reduced from 81 to $72 \mathrm{~g} \mathrm{~N}_{\text {grain }} \mathrm{g}^{-1} \mathrm{~N}_{\text {plant }}$ when applied with $240 \mathrm{~kg} \mathrm{~N} \mathrm{ha}{ }^{-1}$ (Chalmers et al. 1998). 
The quinoa "Tango" variety had higher GNE than the other varieties in both years. The GNE correlated significantly and negatively with the rates of nitrogen fertilizer application. This finding is in agreement with the previous results of Hayati et al. (1996), indicated that seed can accumulate dry matter without nitrogen accumulation, and apparently need only minimal supply of nitrogen to maintain the metabolic processes necessary to sustain dry matter accumulation.

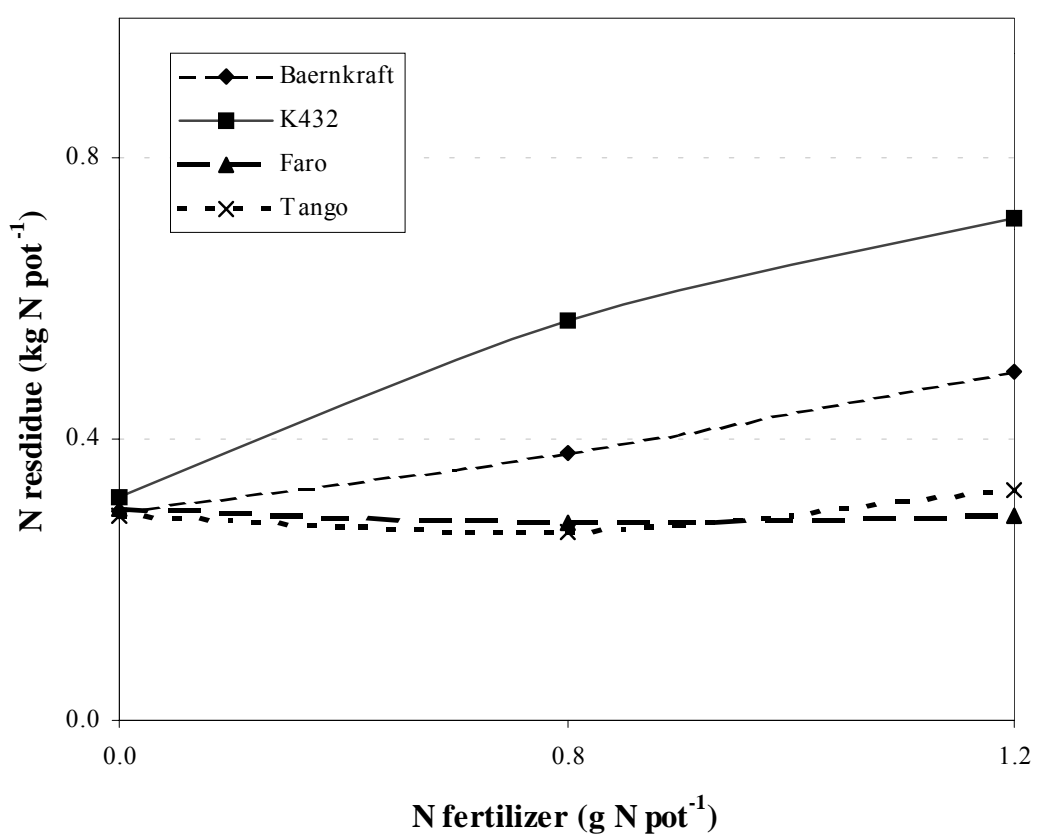

Fig 4.1: The measurement of nitrogen residues in soil at the harvesting period of amaranth (Bärnkraft and K432) and quinoa (Faro and Tango) applied with three different rates of nitrogen fertilizer in the year 2002

The results of nitrogen residues in the soil at the harvesting period of amaranth and quinoa are presented in Fig 1. We found that the plants had different rates of nitrogen uptake from the soil. Nitrogen residues in soil were negative correlated with the NHI and NUE values. Quinoa had clearly better nitrogen absorption efficiency than amaranth. The differences between quinoa cultivars were quite low when compared with amaranth. Amaranth cultivar "K432" showed the highest nitrogen residues in soil when compared with the other cultivars. However, Kaul et al. (1996) suggested that the mineral nitrogen content of the soil at the harvesting period depends much more on the soil properties and/or the weather conditions than on 
the crops' species. In this study, all soil samples were prepared at the same conditions. Thus, the differences in soil nitrogen residues should be only affected by the species of plants. It should be noticed that the interactions between nitrogen fertilizer levels and cultivars significantly affected all factors and parameters investigated in this study.

\subsection{Conclusions}

Nitrogen fertilizer application affected the increase of grain weight, biomass, grain yield and $\mathrm{HI}$ in amaranth and quinoa. Nitrogen accumulations in plant and grain correlated with the nitrogen fertilizer rates. Nitrogen use efficiency, nitrogen utilization efficiency, nitrogen harvest index and grain produced per unit of grain nitrogen decreased with increased nitrogen fertilizer rates. Rates of nitrogen fertilizer higher than $0.8 \mathrm{~g} \mathrm{~N}_{\text {pot }}{ }^{-1}$ did not increase the nitrogen uptake efficiency. Nitrogen use efficiency was related to the nitrogen utilization and nitrogen uptake efficiencies. Hence, any breeding for improvement the nitrogen utilization efficiency could be necessary done. Quinoa had higher grain yield and HI than amaranth. For improvement the yield of quinoa, nitrogen uptake efficiency might be also considered for breeding programs.

\section{Acknowledgements}

This work was supported by the Ministry of Science and Culture, Niedersachsen, Hannover, Germany and the Postharvest Technology Institute, Chiang Mai University, Chiang Mai, Thailand. We would also gratefully acknowledge Dr. Ernst Kübler from the University of Hohenheim for supplying the seed material.

\subsection{References}

Aufhammer, W., H. P. Kaul, P. Herz, E. Nalborezyk, A. Dalbiak, M. Gontarezyk, 1995: Grain yield formation and nitrogen uptake of amaranth. Eur. J. Agron. 4, 379-386.

Bressani, R., J. M. Gonzalez, L. G. Elias, M. Melgar, 1987: Effect of fertilizer application on the yield, protein and fat content, and protein quality of raw and cooked grain of three amaranth species. Plant Food Hum. Nutr. 37, 59-67

Chalmers, A.G., C. J. Dyer, R. Sylvester-Bradley, 1998: Effects of nitrogen fertilizer on the grain yield and quality of winter oats. J. Agric. Sci. 131, 395-407.

Elbehri, A., D. H. Putnam, M. Schmitt, 1993: Nitrogen fertilizer and cultivar effects on yield and nitrogen-use efficiency of grain amaranth. Agron. J. 85, 120-128. 
Fleming, J.E. and N. W. Galwey, 1995: Quinoa (Chenopodium quinoa). In Cereals and Pseudocereals. J.T. Williams (ed.) 1995, Chapman and Hall. London. pp129-186.

Hayati, R., D. B. Egli, S. J. Crafts-Brandner, 1996: Independence of nitrogen supply and seed growth in soybean: studies using an in vitro culture system. J. Exp. Bot. 47, 33-40.

Henderson, T. L., B. L. Johnson, A. A. Schneiter, 2000: Row spacing, plant population, and cultivar effects on grain amaranth in the northern great plains. Agron. J. 92, 329-336.

Houba, V. J. G., J. Novozamsky, A. W. M. Huygregts, J. J. van der LL, 1986: Comparison of soil extraction by $0.01 \mathrm{M} \mathrm{CaCl}_{2}$, by EUF and by some conventional extraction procedures. Plant and Soil 96, 433-437.

Jacobsen, S.E., I. Jørgensen, O. Stølen, 1994: Cultivation of quinoa (Chenopodium quinoa) under temperate climatic conditions in Denmark. J. Agric. Sci. 122, 47-52.

Jacobsen, S.E., 1997: Adaptation of quinoa (Chenopodium quinoa) to Northern European agriculture: studies on developmental pattern. Euphytica 96, 41-48.

Kaul, H. -P., W. Aufhammer, W. Wägner, 1996: Dry matter and nitrogen accumulation and residues of oil and protein crops. Eur. J. Agron. 5, 137-147.

Moll, R. H., E. J. Kamprath, W. A. Jackson, 1982: Analysis and interpretation of factors which contribute to efficiency of nitrogen utilization. Agron J. 74, 562-564.

Myers, R., 1998: Nitrogen fertilizer effect on grain amaranth. Agron. J. 90, 597-602.

National Research Council, 1989: Lost Crops of the Incas: Little-known Plants of the Andes with Promise for worldwide Cultivation, National Academy Press, Washington, D.C.

Noulas, C., P. Stamp, A. Soldati, M. Liedgens, 2004: Nitrogen use efficiency of spring wheat genotypes under field and lysimeter conditions. J. Agron. Crop Sci. 190, 111-118.

Risi, J., and N. W. Galwey, 1991: Genotype x Environment interaction in the Andean grain crop quinoa (Chenopodium quinoa) in temperate environments. Plant Breeding 107, 141147.

Sage R. F. and R. W. Pearcy, 1987: The nitrogen use efficiency of $\mathrm{C}_{3}$ and $\mathrm{C}_{4}$ plants. I. Leaf nitrogen, growth, and biomass partitioning in Chenopodium album (L.) and Amaranthus retroflexus (L.). Plant Physiology 84, 954-958.

Salado-Navarro, L. R., R. K. Hinson, T. R. Sinclair, 1985: Nitrogen partitioning and dry matter accumulation in soybeans with different seed protein concentrations. Crop Sci. 25, 451455.

Sinclair, T.R., and C. T. de Wit, 1975: Photosynthate and nitrogen requirements for seed production by various crops. Science 18, 565-567.

Spehar, C. R., R. L. B. Santos, S. E. Jacobsen, 1998: Andean grain crop introduction to the Brazilian Savannah. In: International Conference on Sustainable Agriculture on Tropical and Subtropical Highlands with Special Reference to Latin America, Rio de Janeiro, Brazil.

Steel, R.G., and J. H. Torry, 1980: Principles and procedures of statistics, 2nd edn. McGrawHill, New York.

Sweeney RA, Rexroad PR, 1987: Comparison of LECO FP-228 "Nitrogen Determination" with AOAC copper analyst Kjeldahl method for crude protein. J. AOAC International 70, 1028-1030.

Wyss, C. S., J. R. Czyzewicz, F. E. Below, 1991: Source-sink control of grain composition in maize strains divergently selected for protein concentration. Crop Sci. 31, 761-766. 


\title{
5 Changes in pseudocereal protein fractions in relation to nitrogen fertilization
}

\begin{abstract}
The purpose of this study was to investigate the effects of nitrogen fertilizer application on seed proteins of amaranth (Amaranthus spp.) and quinoa (Chenopodium quinoa Willd). Nitrogen fertilizer was applied with three different rates at $0,0.8$, and $1.2 \mathrm{~g} \mathrm{~N}_{\text {pot }}^{-1}$, respectively. The following compounds were analyzed: protein fractions, SDS-PAGE patterns and amino acid composition. Seed proteins were fractionated as albumin-1, albumin-2, globulin and glutelin. Nitrogen fertilizer application affected the albumin-1 fraction in both plant species. Electrophoresis patterns were also related to the plant species. Amaranth and quinoa had high contents of lysine, but low contents of methionine. Albumin-1 fractions were high in lysine content while albumin-2 fractions had high leucine content. Globulin fractions contained higher amounts of essential amino acids than the other fractions, but lower content of lysine. Glutelin fractions were well balanced in their essential amino acids with exception of methionine.
\end{abstract}

\subsection{Introduction}

Food allergy is defined as an adverse reaction to foods that is mediated immunological and involves specific imunoglubolin E (IgE) or non-IgE mechanisms (Papageorgiou, 2001). Within the European Union, food allergy affects about 5 to 10 million people (Crevel, 2001). Wheat and other cereal grains such as rice, maize and barley are well known sources of food allergies (Nakamura, 1987). These allergens were not observed in amaranth (Amaranthus spp.) and quinoa (Chenopodium quinoa Willd). Therefore, they may be used as an alternative source for non-allergenic food products.

Pseudocereals are dicotyledons consisting of starchy seeds. Amaranth and quinoa belong to this group. They are also protein-rich and have a better balance in their amino acid composition than other cereals such as wheat, maize and oat. Therefore, the sum of essential amino acids (EAA) in amaranth and quinoa seeds is closely related to the recommended amino acid pattern of the FAO/WHO standard (Ahamed et al., 1998). The major storage proteins in amaranth and quinoa seeds were globulins and also a different amino acids composition in each protein fraction was found (Bressani and Garcia-Vela., 1990; Gorinstein et al., 1991). Nitrogen supply was the dominant effect on protein accumulation in the seed. Hayati et al. (1996) 
reported that in soybean seeds the nitrogen accumulation and concentration were related to the nitrogen concentration in the media under in vitro culture conditions. Paek et al. (1997) showed that raising soybean seed protein concentration through enhanced plant nitrogen affected the quality of seed storage proteins. Nitrogen is translocated mainly via phloem in form of amino acids. Higher protein contents in rapeseeds was found to correlate with higher amino-nitrogen translocation rates in the phloem (Lohaus and Moellers, 2000). Protein fractions in wheat grains (Triboï et al., 2003) and amino acids composition changes in birch plants (Näsholm and McDonald, 1990) related to nitrogen fertilizer application have been reported. However, information about the effects of nitrogen fertilizer on the protein properties of amaranth and quinoa are very limited. The purposes of this study were to determine the contents of albumin, globulin and glutelin in amaranth and quinoa seeds as well as their amino acid compositions depending on nitrogen supply.

\subsection{Materials and methods}

Plant materials were grown and prepared as described in chapter 4.

\subsubsection{Protein Extraction}

Protein fractions were extracted stepwise according to the following methods (Delgado, 1995; Delgado et. al, 1999). The meal (10 g) was extracted with a solvent: sample ratio of 10:1 $(\mathrm{v} / \mathrm{w})$ and vigorously shaken at $4{ }^{\circ} \mathrm{C}$. The extracts were separated by centrifuging at $9000 \mathrm{~g}$ for 20 min. Each step was repeated twice. The sequence of the used solvents was the following: $0.5 \mathrm{M} \mathrm{NaCl}$, then separated by dialysis (ZelluTrans/Roth 3, 5, Carl Roth, Germany) against water [albumins-1 (Albu-1) and globulins (Glob)], Albumins-2 (Albu-2) fraction was extracted with water after removing Albu-1 and Glob. The last fraction [glutelin (Glut)] prepared at $20^{\circ} \mathrm{C}$ by extraction with 0.125 sodium borate buffer $(\mathrm{pH} 10)$ containing $3 \%(\mathrm{v} / \mathrm{v})$ 2-mercaptoethanol (2-ME) plus $0.5 \%(\mathrm{w} / \mathrm{v})$ sodium dodecyl sulphate (SDS). Then all fractions were freeze-dried.

\subsubsection{Protein Determination}

Protein contents in each fraction were determined by the change in absorption of Coomassie Blue Dye when it binds to proteins and in comparison with a standard protein (Bovine serum albumin) curve (Bradford, 1976). Glob content was calculated as the difference between 
crude protein, Albu-1, Albu-2, Glut and the insoluble rest. The rest fraction has been pooled with the prolamin fractions. Crude protein and protein content of the rest were determined as nitrogen with the Dumas combustion method using an automated LECO CN analyzer model CN2000 (LECO, St. Joseph, MI) and a conversion factor of 5.85 for the calculation of the protein content (Sweeney and Rexroad, 1987).

5.2.3 Protein Characterization with Sodium Dodecyl Sulphate Polyacrylamid Gel Electrophoresis (SDS-PAGE).

SDS-PAGE was performed according to Laemmli (1970) using a gel concentration of $10 \%$ with some modifications from Delgado (1995) and Gorinstein et al. (2001). Protein molecular weight identified by SDS polyacrylamide gel electrophoresis (PAGE) using the Biometra Mini-Power Pack 040-100 and PP 2000 with glass plates (6.6 x $7.7 \mathrm{~cm})$ (Biometra, Germany). Protein standards mixture IV (Merck, Germany) were applied to determine protein subunit molecular masses in $\mathrm{kDa}$ : cytochrome C (12); myoglobin (16); carboanhydrase (30); ovalbumin (42); albumin (66); ovotransferrin (78).

Amino acid composition. Determination as described in chapter 3.

\subsection{Results and Discussion}

Protein Fractions. The seed protein fractions are presented in Table 5.1. The distribution of the single fractions within the proteins was mainly depending on the cultivars. The average ratio of Albu-1 : Albu-2 : Glob : Glut : rest was 8.9 : $3.3: 53.6: 5.7: 28.5$. Glob was the main protein fraction followed by Alb-1. In this study, the Alb and Glob fractions were higher than in that previous reported by Bressani and Garcia-Vela (1990). The different values may be caused by the differences in the plant material, methods and amount of fractions used to extraction. Albu-1 fraction was significantly decreased after nitrogen application. Albu1 content was negatively correlated with the Glob fractions and should be affected during seeding development stage. According to Tabe et al. (2002), the down regulation of prolamins fraction in opaque 2 mutant in maize was associated with a compensatory increase in nitrogen storage in other seed protein fractions. The functional proteins are accumulated in grain mainly during the cell division stage, whereas the storage proteins are accumulated mainly during the filling period (Triboï et al., 2003). Martre et al. (2003) found that the accumulation 
of storage proteins is significantly enhanced by nitrogen supply, whereas functional protein content is less affected.

Table 5.1 Effect of nitrogen fertilizer on seed protein fractions

\begin{tabular}{llccccc}
\hline Plants & Varieties & \multicolumn{5}{c}{ Fraction (\%) $^{\dagger}$} \\
\cline { 3 - 6 } Species & & Albu-1 & Albu-2 & Glob & Glut & Rest $^{\ddagger}$ \\
\hline Amaranth & Bärnkraft & $10.5 \mathrm{~b}$ & $3.6 \mathrm{~b}$ & $51.6 \mathrm{a}$ & $5.6 \mathrm{~b}$ & $28.7 \mathrm{~b}$ \\
& K432 & $6.2 \mathrm{a}$ & $2.1 \mathrm{a}$ & $51.0 \mathrm{a}$ & $8.2 \mathrm{c}$ & $32.5 \mathrm{~b}$ \\
Quinoa & Faro & $7.0 \mathrm{a}$ & $6.2 \mathrm{c}$ & $60.2 \mathrm{~b}$ & $3.2 \mathrm{a}$ & $23.4 \mathrm{a}$ \\
& Tango & $12.0 \mathrm{c}$ & $1.4 \mathrm{a}$ & $51.4 \mathrm{a}$ & $5.9 \mathrm{~b}$ & $29.3 \mathrm{~b}$ \\
\hline
\end{tabular}

Nitrogen levels ${ }^{\S}\left(\mathrm{g} \mathrm{N} \mathrm{pot}^{-1}\right)$

\begin{tabular}{cccccc}
\hline 0 & $10.7 \mathrm{~b}$ & 3.7 & 51.0 & 6.2 & 28.5 \\
0.8 & $8.5 \mathrm{a}$ & 3.7 & 54.6 & 6.1 & 27.2 \\
1.2 & $7.4 \mathrm{a}$ & 2.7 & 55.1 & 5.0 & 29.7
\end{tabular}

The values of mean which are following by the same letter had $p>0.05$, and therefore, they were not characterized as significant difference

${ }^{\dagger}$ Protein fractions: Albu-1, albumin-1; Albu-2, albumin-2; Glob, globulin; Glut, glutelin. Expressed as total protein percentage

Protein content of the rest was determined as nitrogen with the Dumas combustion method

$\S$ Average values of all plant species and cultivars

Electrophoresis patterns. The SDS-PAGE in one dimension was used to analyze heterogeneity in the size of protein in each fraction. The electrophoresis patterns are shown in Figure 5.1 and 5.2. The study found a variation in all protein fractions of the amaranth cultivars but not in quinoa. The result in amaranth was in agreement with previous findings reported by Gorinstein et al. (1991), showing the variations in some minor bands. Nitrogen application did not change the electrophoresis patterns of all cultivars. 

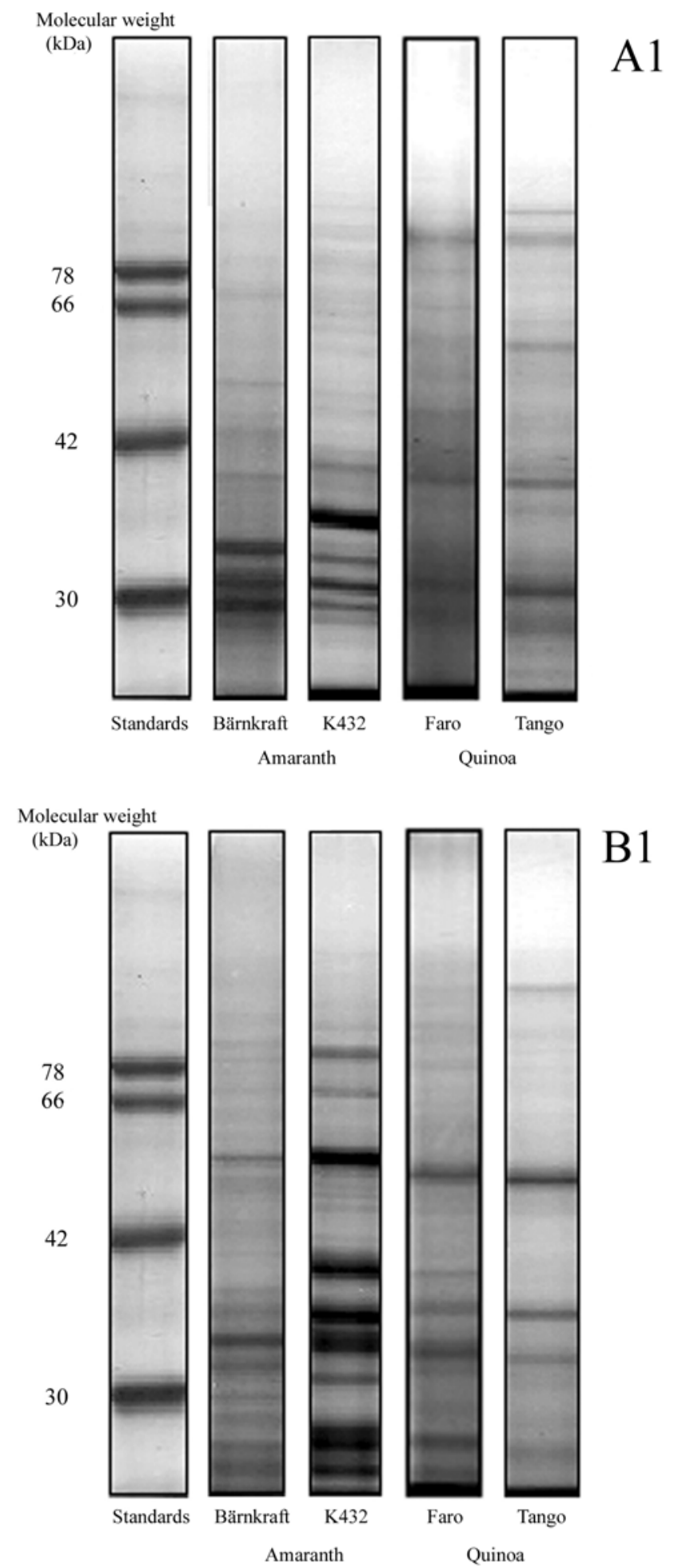

Figure 5.1 SDS-PAGE patterns of Albu-1 fractions (A1), Albu-2 fractions (B1) of amaranth and quinoa at all levels of nitrogen fertilizer 

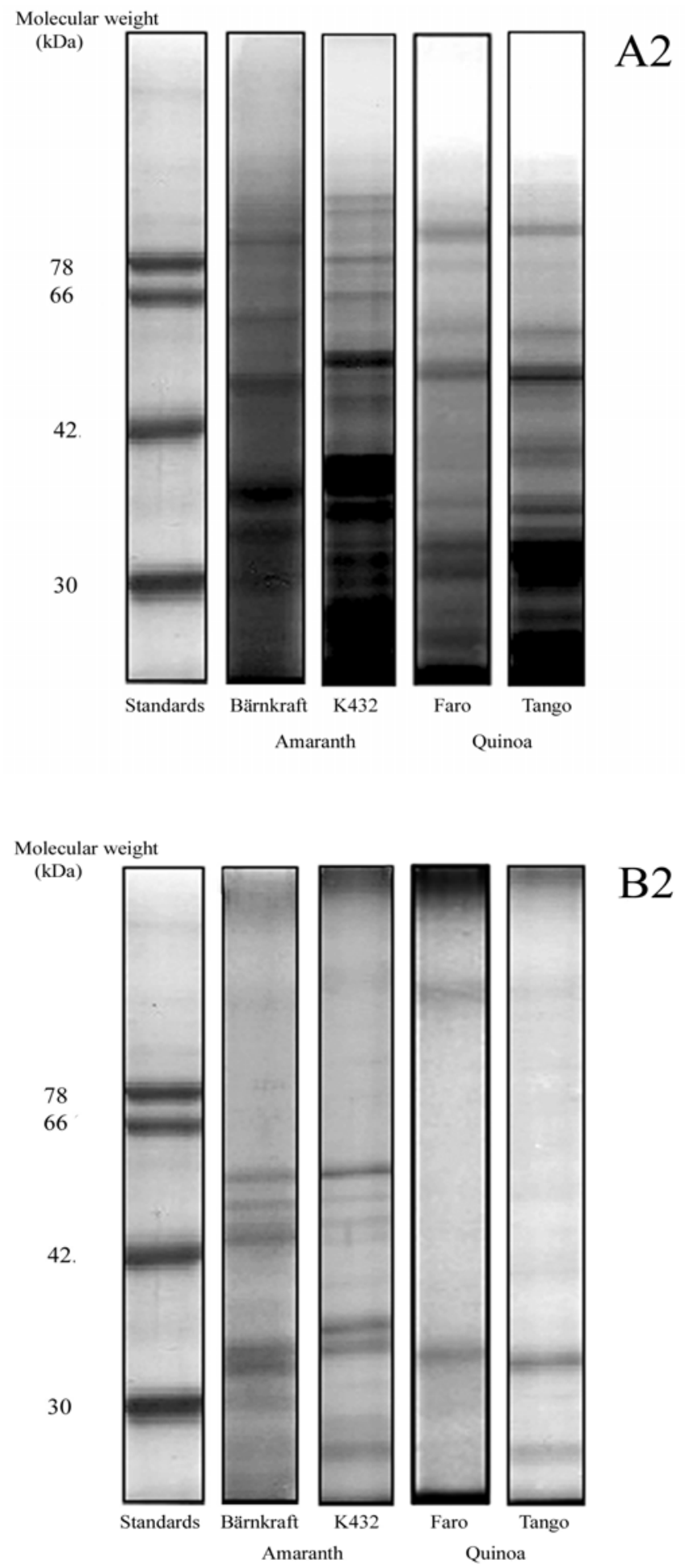

Figure 5.2 SDS-PAGE patterns of Glob fractions (A2) and Glut fractions (B2) of amaranth and quinoa at all levels of nitrogen fertilizer

In Albu-1 fractions (Figure 5.1), amaranth variety 'Bärnkraft' and 'K432' had differences in protein subunits pattern. Albu-1 of 'Bärnkraft' had a lower molecular weight (MW) than 
'K432'. 'Bärnkraft' contained three major subunits at 28, 30, and $33 \mathrm{kDa}$, respectively, while 'K432' consisted of four major subunits with MW of 26, 28, 30 and $34 \mathrm{kDa}$. These results were similar to the protein patterns of amaranth reported by Drzewiecki et al. (2003).

For quinoa, Albu-1 fractions showed a wide range of major protein subunits within the range of 25-83 kDa. Both varieties had similar major protein bands at 25, 28, 36, 39, 78 and $83 \mathrm{kDa}$. Difference in the major subunits between 'Faro' and 'Tango' were 47 and $57 \mathrm{kDa}$. Protein patterns of quinoa were similar to soybean, which had major subunits under $30 \mathrm{kDa}$ as well as above 42 and $78 \mathrm{kDa}$ (Gorinstein et al., 2001).

The major proteins in Albu-2 fractions of amaranth and quinoa are presented in Figure 5.1. The major protein subunits of amaranth could be divided into three groups with the range of 22-25, 31-39 and 51-54 kDa. The major protein subunits in amaranth variety 'Bärnkraft' were 31 and $57 \mathrm{kDa}$. The 'K432' variety contained several major protein subunits when compared with 'Bärnkraft' variety $(22,28,31,34,39,53,64$, and $72 \mathrm{kDa}$, respectively). Both varieties of quinoa consisted of four major subunits with MW of 23, 31, 35 and $52 \mathrm{kDa}$. The SDSPAGE patterns of Glob in amaranth and quinoa seeds are shown in Figure 5.2 . The predominant protein subunits of 'Bärnkraft' were 29, 34, 38 and $52 \mathrm{kDa}$. The 'K432' variety had several low MW protein subunits in the range of 22-26 kDa and four major protein subunits with MW of 30, 34, 38 and $64 \mathrm{kDa}$. In this study, the protein patterns in amaranth seeds consisted of the higher molecular weight proteins than that reported by Gorinstein et al. (1991). Glob electrophoretic profiles of both quinoa varieties were similar in the major protein subunits. There were distinct protein subunits within the range of $29-32 \mathrm{kDa}$ and other four protein bands at 23, 35, 58 and $78 \mathrm{kDa}$.

For Glut fractions, similar patterns of protein bands in amaranth 'Bärnkraft' and 'K432' were shown (Figure 5.2). The major protein subunits of 'Bärnkraft' were found at 32, 34 48, 53 and $57 \mathrm{kDa}$. For 'K432', the major protein bands at 24, 32, 34 and $55 \mathrm{kDa}$ were detected. The patterns of amaranth are in accordance with Gorinstein et al. (1991). Quinoa had less protein bands compared to amaranth. The variety 'Faro' consisted of two major protein subunits with MW of 32 and $94 \mathrm{kDa}$, while 'Tango' contained the two subunits of 25 and $32 \mathrm{kDa}$.

Amino acid composition. In Figure 5.3 the amino acid composition of amaranth and quinoa seeds is presented. The following amino acids were analyzed: aspartic acid (Asp), serine (Ser), glutamic acid (Glu), histidine (His), glycine (Gly), arginine (Arg), threonine (Thr), alanine (Ala), proline (Pro), cysteine (Cys), tyrosine (Tyr), valine (Val), methionine (Met), lysine (Lys), isoleucine (Ile), leucine (Leu) and phenylalanine (Phe). Amaranth flour contained sig- 
nificantly lower amounts of Val and Leu than quinoa. The sums of essential amino acids

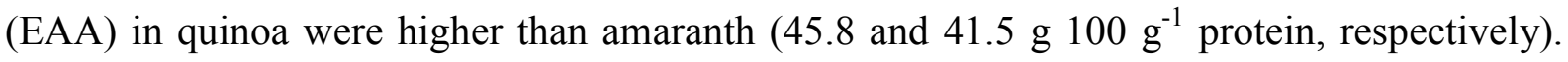
Amino acids concentrations responded to nitrogen fertilizer application were showed in Figure 5.3. Pro and Glu contents were negatively correlated with Arg content. Plants take up nitrogen preferably as ammonia and then convert it into glutamine (Gln) and Glu. These two amino acids act as nitrogen donors for the Pro and Arg biosynthesis (Verma and Zhang,

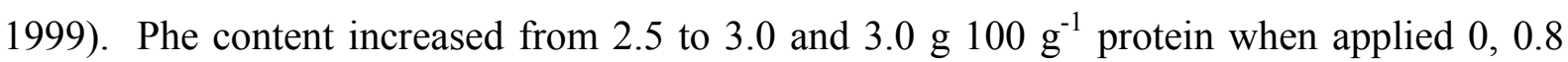
and $1.2 \mathrm{~g} \mathrm{~N}$ pot $^{-1}$, respectively. Bullman et al. (1994) observed in barley, that the Phe content was increased proportionally to the rising rates of nitrogen fertilizer supply. Amaranth and

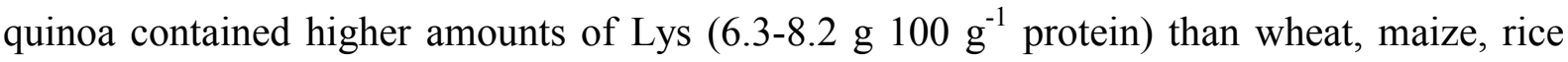

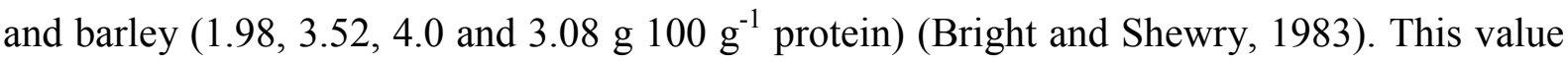
is also higher than recommended (5.5 g $100 \mathrm{~g}^{-1}$ protein) in the FAO/WHO standard (Ahamed et al., 1998). The content of Met, lower than FAO/WHO standard, might be affected by Cys synthesis (Clarke and Wiseman, 2000). However, total EAA content was not changed after nitrogen application. For human diet, nitrogen fertilizer application might be advantage to improve the nutritional values by increasing protein content and maintaining most of essential amino acids content.

In the Albu-1 fraction of amaranth and quinoa the amino acid compositions were different (Figure 5.4). However, EAA contents of amaranth and quinoa were not significantly different

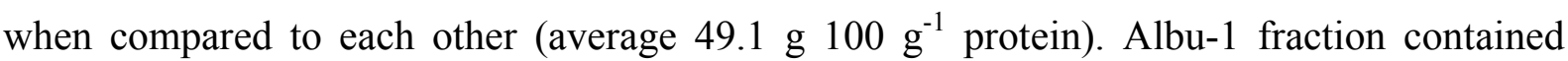
more Gly than other fractions. On the other hand, the concentration of Gly found in this study

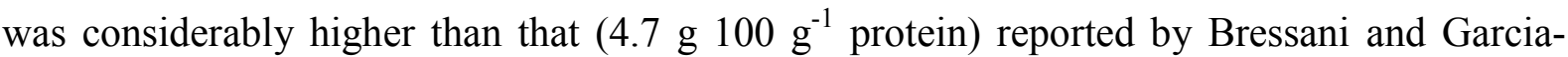
Vela (1990). After nitrogen application, the EAA content decreased from 50.3 to 48.7 and

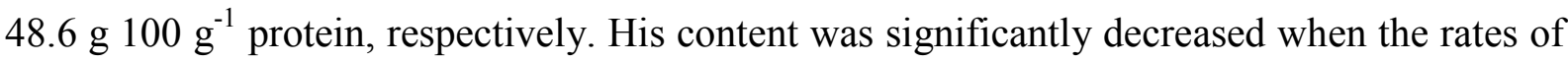
nitrogen fertilizer increased. Met content was lower than FAO/WHO standard (1.8 and $3.5 \mathrm{~g}$ $100 \mathrm{~g}^{-1}$ protein, respectively). Phe increased along with the increasing rates of nitrogen application.

Albu-2 fractions differed in amino acids composition depending on cultivars and nitrogen ap-

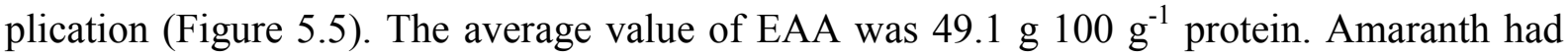
higher content of Ser than quinoa. It was found that the concentrations of Asp, Arg and Leu were affected by nitrogen application. However, only Arg content was distinctly decreased after increased nitrogen fertilizer rates. Met content was low in this fraction. Albu-2 fractions had higher content of Leu than that of Albu-1 and Glob fractions. 

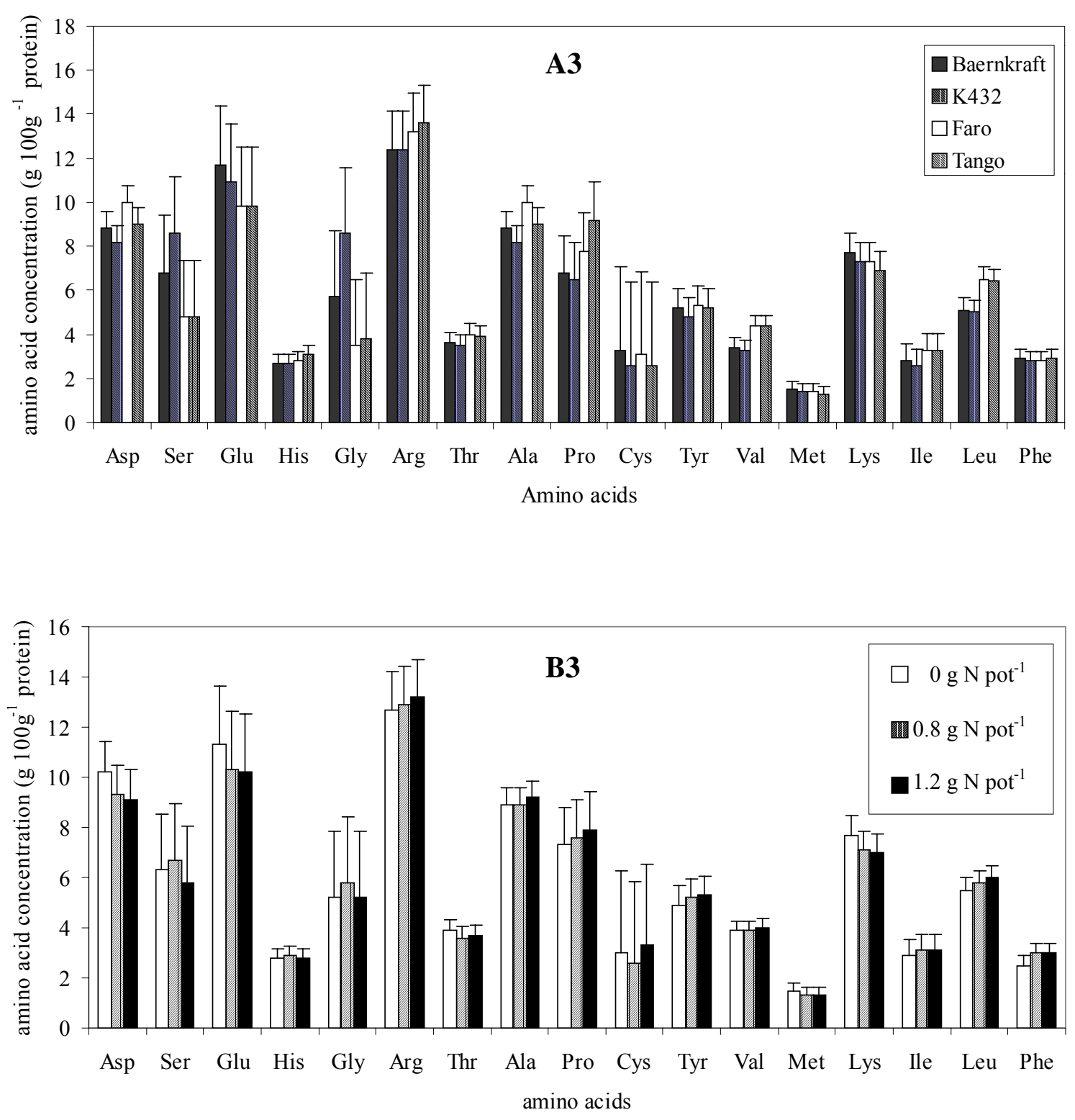

Figure 5.3 Amino acid concentrations (A3) of amaranth and quinoa and (B3) at different rates of nitrogen applications (average of all species and cultivars). Bars indicate LSD 0.05 . 

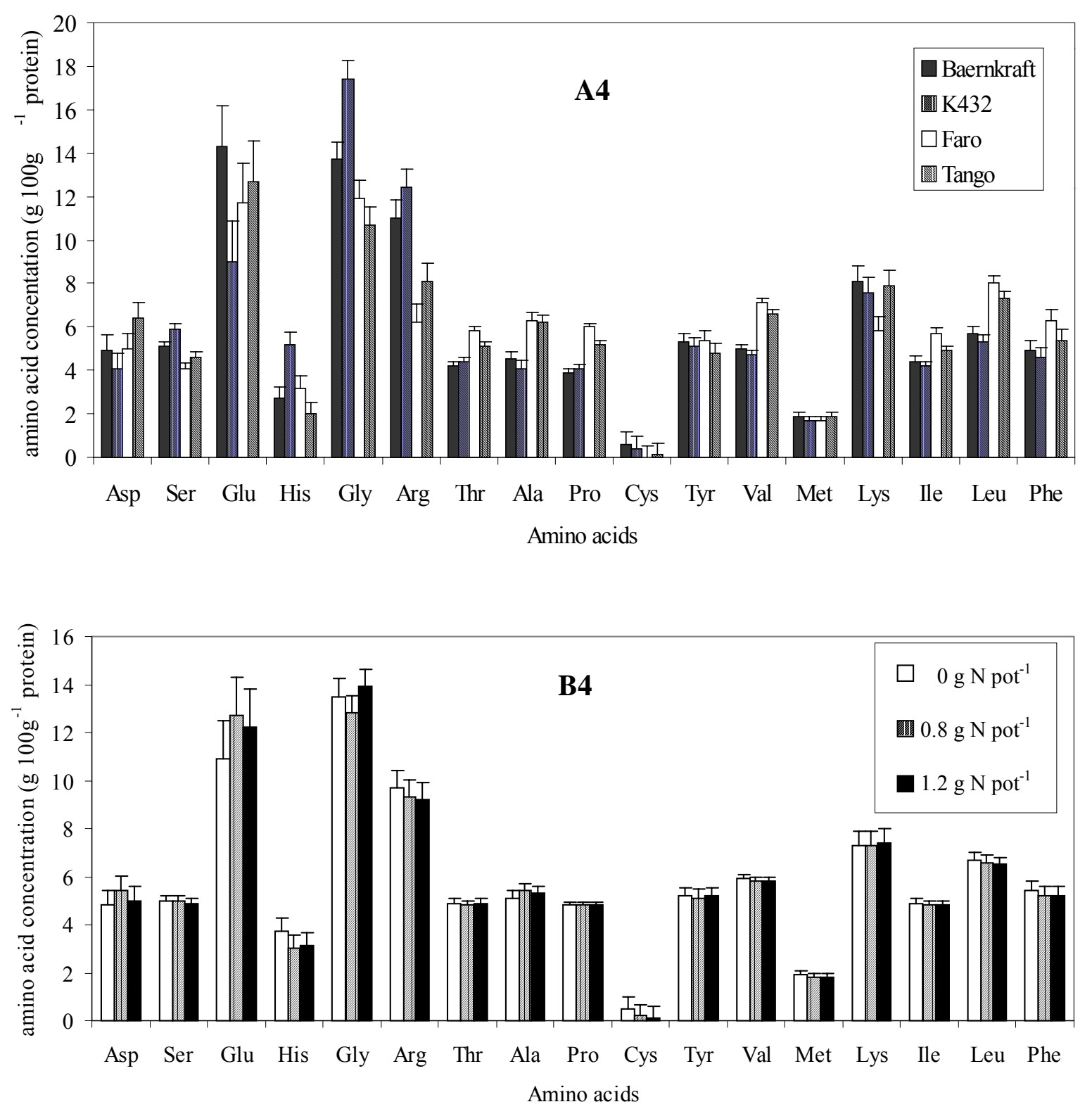

Figure 5.4 Amino acid concentrations in Albu-1 fractions (A4) of amaranth and quinoa and (B4) at different rates of nitrogen applications (average of all species and cultivars). Bars indicate LSD 0.05 . 


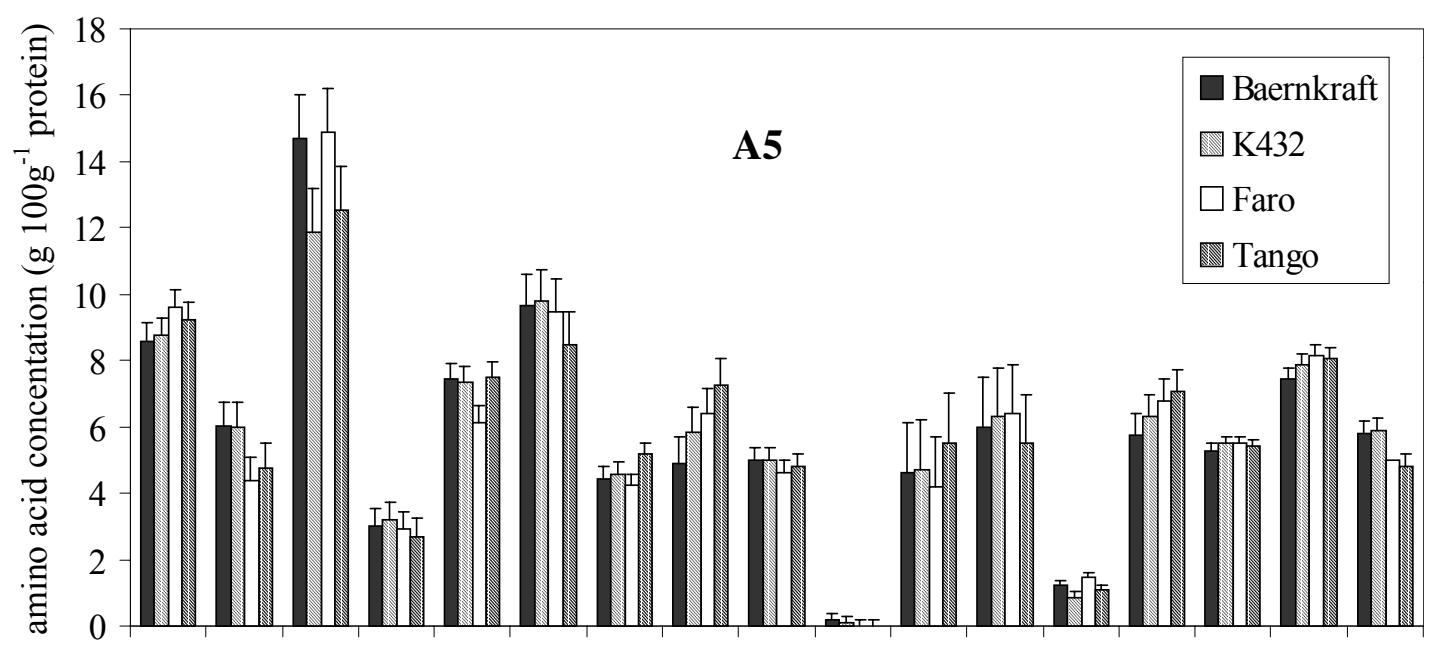

Asp Ser Glu His Gly Arg Thr Ala Pro Cys Tyr Val Met Lys Ile Leu Phe Amino acids

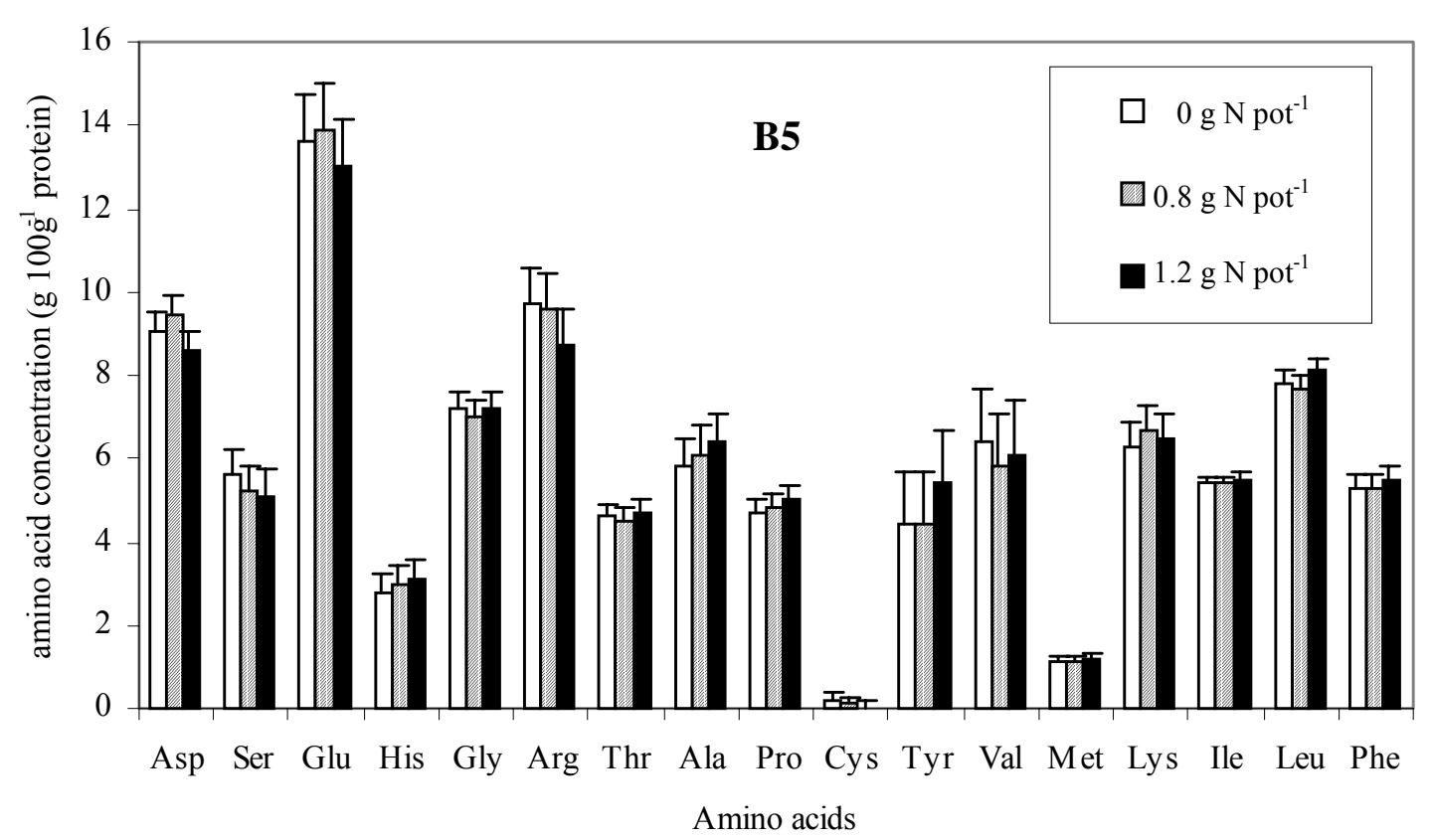

Figure 5.5 Amino acid concentrations in Albu-2 fractions (A5) of amaranth and quinoa and (B5) at different rates of nitrogen applications (average of all species and cultivars). Bars indicate LSD 0.05 . 
Amino acid composition in Glob fractions was influenced by cultivars and nitrogen fertilizer.

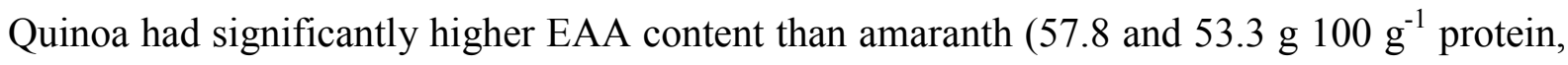
respectively). The content of sulfur containing amino acid Met was decreased along with the rates of nitrogen fertilizer application, while Ile and Phe were increased (Figure 5.6). Nakasathien et al. (2000) reported that increasing nitrogen supply affected the sulfur amino acid synthesis. Phe content was high in this fraction. Lys and Cys contents were lower than in the other fractions. Amaranth and quinoa contained less Lys than Phaseolus vulgaris (2.88 and $10.75 \mathrm{~g} 100 \mathrm{~g}^{-1}$ protein, respectively) when compared with previous reported by Chagas and Santoro (1997). Shewry et al. (1995) proposed that seed Glob fractions were deficient in Cys and Met. In contrast, Gorinstein et al. (2001) showed in their study that Glob was rich in Met and Cys, Ile and Val. Phe content was increased in respond to increasing rates of nitrogen supplied. Therefore, increasing in Phe content of amaranth and quinoa flour should be affected by Glob fractions.

Glut fractions of amaranth and quinoa varied also in amino acid composition (Figure 5.7). Quinoa 'Tango' had the highest EAA content when compared with the other cultivars (51.5

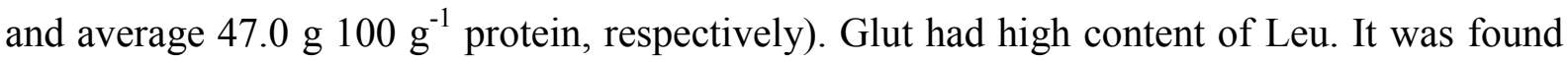
that Lys content was higher than soybean in previous report by Gorinstein et al. (2002). However, Lys content in glutelin fractions was lower than Albu-1 and Albu-2 fractions. Alb fractions were the major sources of lysine, which is synthesized during seed development (Shewry and Casey, 1999). 

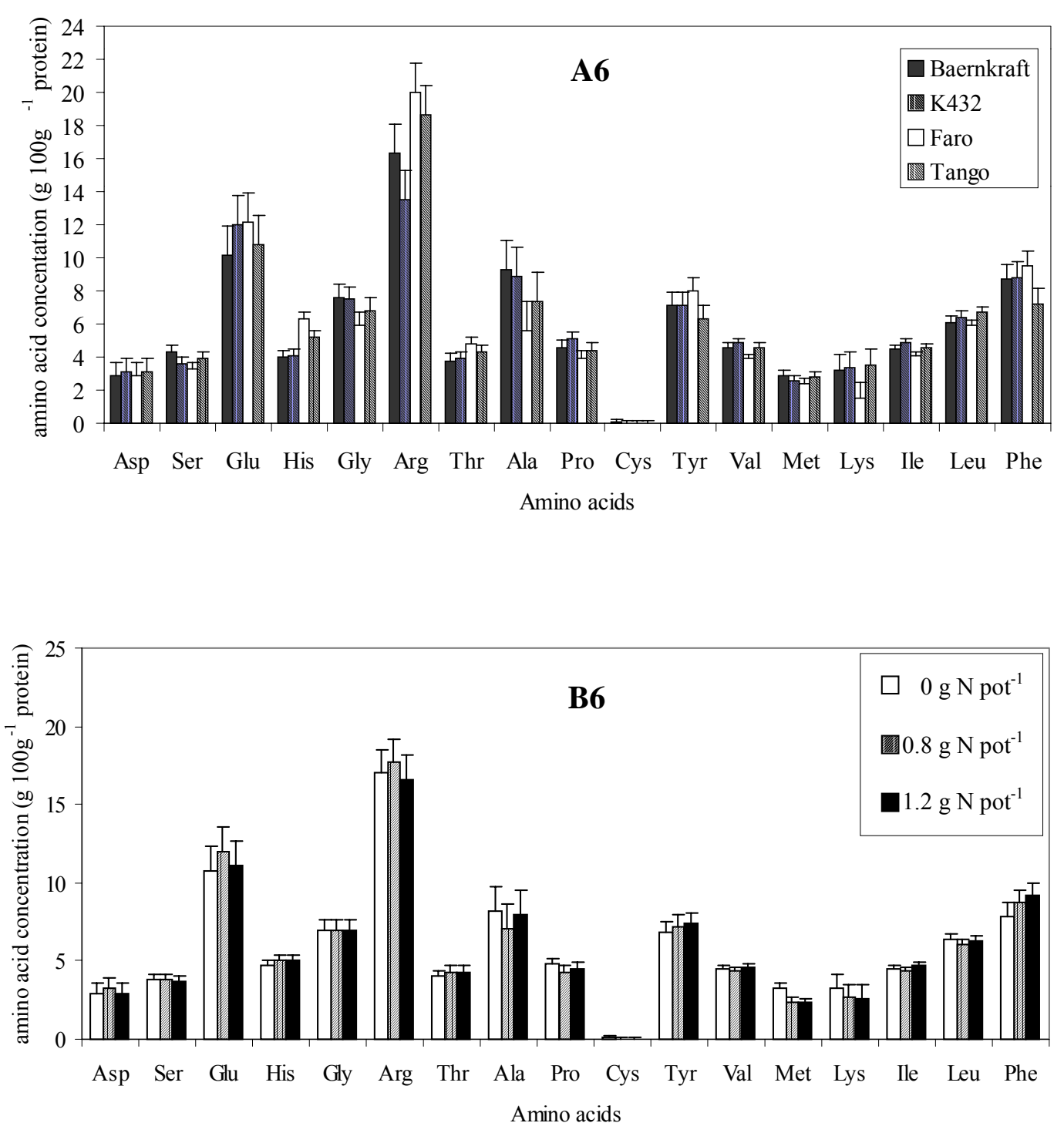

Figure 5.6 Amino acids concentration in Glob fractions (A6) of amaranth and quinoa and (B6) at different rates of nitrogen applications (average of all species and cultivars).. Bars indicate LSD 0.05 . 

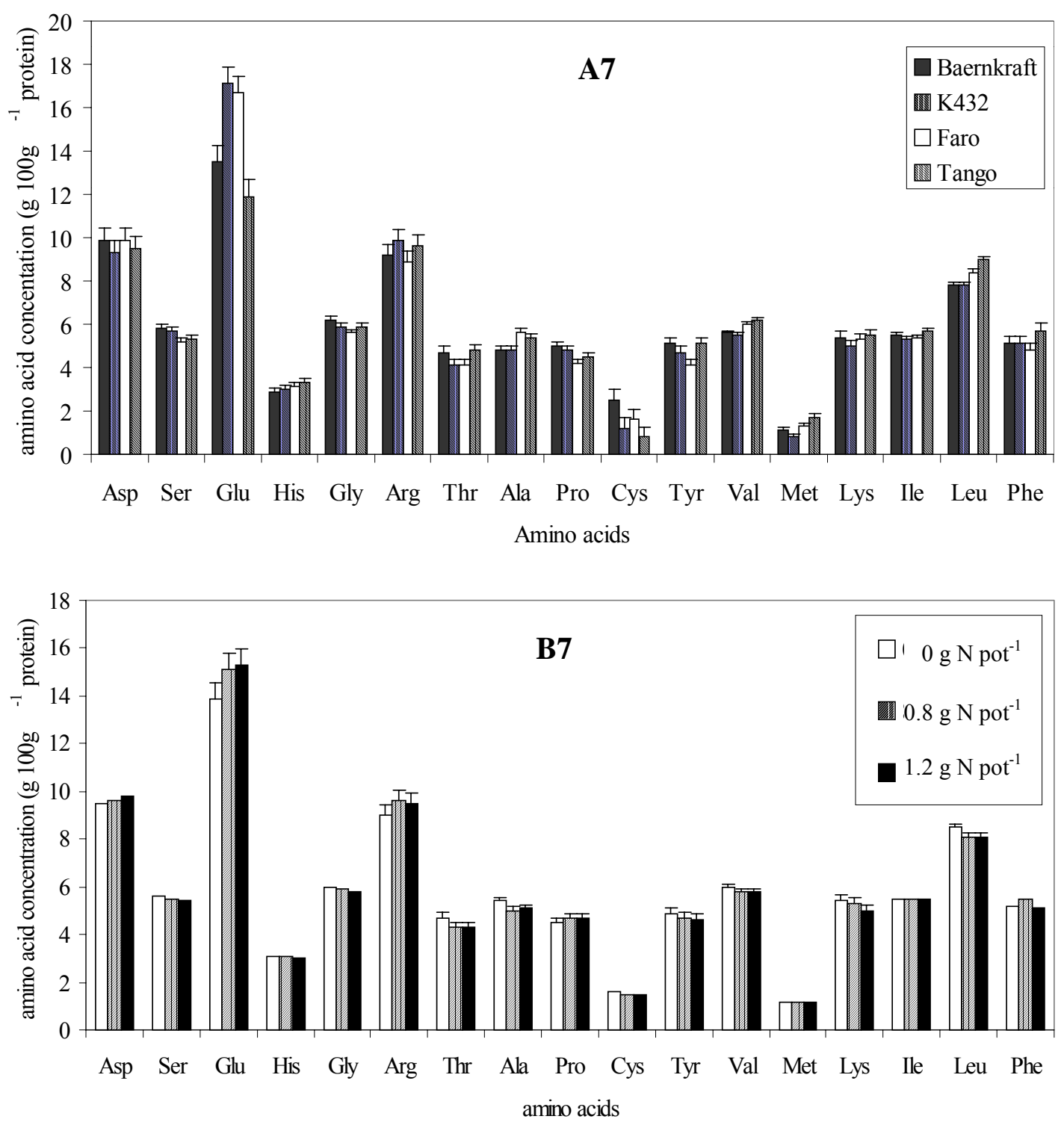

Figure 5.7 Amino acid concentrations in Glut fractions (A7) of amaranth and quinoa and (B7) at different rates of nitrogen applications (average of all species and cultivars). Bars indicate LSD 0.05 . 


\subsection{Conclusions}

Nitrogen fertilizer application affected both protein fractions and amino acid composition of amaranth and quinoa. Decreasing of Albu-1 fraction was affected by seed development. The sum of essential amino acids was not affected by the nitrogen application. Albu-1 fractions had high lysine content while Albu-2 fractions were high in leucine. Glob fractions contained higher concentrations of essential amino acids than the other fractions, but lower content of lysine. Glut fractions were well-balanced in their essential amino acid composition with exception of methionine. Nitrogen fertilizer application could be advantage for improve the nutritional values of human diet by increasing protein content and maintaining essential amino acid content.

\subsection{References}

Ahamed, N.T.; Singhal, R.S.; Kulkarni, P.R.; Pal, M. A lesser-known grain, Chenopodium quinoa: Review of the chemical composition of its edible parts. Food and Nutr. Bull. 1998, 19, 61-70.

Bradford, M. A rapid and sensitive method for the quantitation of microgram quantities of protein utilizing the principle of protein-dye binding. Anal. Biochem. 1976, 72, 248-254.

Bressani, R.; Garcia-Vela L. A. Protein fractions in amaranth grain and their chemical characterization. J. Agri. Food Chem. 1990, 38, 1205-1209.

Bright, S. W .J.; Shewry, P. R. Improvement of protein quality in cereals. CRC Crit. Rev. Plant Sci. 1983, 1, 49-93.

Bulman, P.; Zarkadas, C. G.; Smith, D. L. Nitrogen fertilizer affects amino acid composition and quality of spring barley grain. Crop Sci. 1994, 34, 1341-1346.

Chagas, E. P.; Santoro, L. G. Globulin and albumin proteins in dehulled seeds of three Phaseolus vulgaris cultivars. Plant Foods Human Nutr. 1997, 51, 17-26.

Clarke, E. J.; Wiseman, J. Developments in plant breeding for improved nutritional quality of soya beans I. Protein and amino acid content. J. Agric. Sci. (Cambridge) 2000, 134, 111 124.

Cohen, S.A.; Michaud, D.P. Synthesis of a fluorescent derivatizing reagent, 6-aminoquinolylN-hydroxysuccinimidyl carbamate, and its application for the analysis of hydrolysate amino acids via high-performance liquid chromatography. Anal. Biochem. 1993, 211, 279287.

Crevel, R. Industrial dimentions of food allergy. Biochem. Soc. Trans. 2001, 30, 941-944.

Delgado, E. Einfluss der Prallzerkleinerung auf die Aenderung der Mehleigenschaften und die mechanische Modifizierung der Weizenproteine. Ph.D. Thesis TU Berlin, Cuvillier-Verlag Goettingen, 1995, 30-34.

Delgado, E.; Mueller, K.; Pawelzik, E. Influence of nitrogen fertilization on protein quality of rye and oat grains. Agribiol. Res. 1999, 52, 337-345.

Drzewiecki, J.; Delgado-Licon, E.; Haruenkit, R.; Pawelzik, E.; Martin-Belloso, O.; Park, Y. S.; Jung, S. T.; Trakhtenberg, S.; Gorinstein, S. Identification and differences of total 
proteins and their soluble fractions in some pseudocereals based on electrophoretic patterns. J. Agric. Food Chem. 2003, 51, 7798-7804.

Gorinstein, S.; Moshe, R.; Greene, L. J.; Arruda, P. Evaluation of four Amaranthus species through proteins electrophoretic patterns and their amino acid composition. J. Agri. Food Chem. 1991, 39, 851-854.

Gorinstein, S.; Delgado-Licon, E.; Pawelzik, E.; Permady, H. H.; Weisz, M.; Trakhtenberg, S. Characterization of soluble amaranth and soybean proteins based on fluorescence, hydrophobicity, electrophoresis, amino acid analysis, circular dichroism, and differential scanning calorimetry measurements. J. Agric. Food Chem. 2001, 49, 5595-5601.

Gorinstein, S.; Pawelzik, E.; Delgado-Licon, E.; Haruenkit, R.; Weisz, M.; Trakhtenberg, S. Characterization of pseudocereal and cereal proteins by protein and amino acid analyses. $J$. Sci. Food Agri. 2002, 82, 886-891.

Hayati, R.; Egli, D. B.; Crafts-Brandner, S. J. Independence of nitrogen supply and seed growth in soybean: studies using an in vitro culture system. J. Exp. Bot. 1996, 47, 33-40.

Laemmli, U.K. Cleavage of structureal proteins during the assembly of bacteriophage T4. Nature 1970, 227, 680-685.

Lohaus, G.; Moellers, C. Phloem transport of amino acids in two Brassica napus genotypes and one B. carinata in relation to their seed protein content. Planta 2000, 211, 833-840.

Martre, P.; Porter, J. R.; Jamieson, P. D.; Triboï, E. Modeling grain nitrogen accumulation and protein composition to understand the sink/source regulations of nitrogen remobilization for wheat. Plant Physiol. 2003, 133, 1959-1967.

Nakamura, R. Allergens in cereals. Chem. Biol. 1987, 25, 739-741.

Nakasathien, S.; Israel, D. W.; Wilson, R. F.; Kwanyuen, P. Regulation of seed protein concentration in soybean by supra-optimal nitrogen supply. Crop Sci. 2000, 40, 1277-1284.

Näsholm, T.; McDonald, A. J. Dependence of amino acid composition upon nitrogen availability in birch (Betula pendula). Physiol. Plantarum 1990, 80, 507-514.

Paek, N. C.; Imsande, J.; Shoemaker, R. C.; Shibles, R. Nutritional control of soybean seed storage protein. Crop Sci. 1997, 37, 498-503.

Papageorgiou, P. S. Clinical aspects of food allergy. Biochem. Soc. Trans. 2001, 30, 901-906.

Shewry, P. R.; Napier, J. A.; Tatham, A. S. Seed storage proteins: structures and biosynthesis. Plant Cell 1995, 7, 945-956.

Shewry P.R.; Casey R. Seed proteins, In Seed Protein; Shewry P. R. and Casey R., Eds.; Kluwer Academy Publishers, Amsterdam, 1999; pp. 1-10.

Sweeney, R. A.; Rexroad, P. R. Comparison of LECO FP-228 "Nitrogen Determination" with AOAC copper analyst Kjeldahl method for crude protein. J. AOAC International 1987, 70, 1028-1030.

Tabe, L.; Hagan, N.; Higgins, T. J. V. Plasticity of seed protein composition in response to nitrogen and sulfur availability. Curr. Opin. plant Biol. 2002, 5, 212-217.

Triboï, E.; Martre, P.; Triboï-Blondel, A. M. Environmentally-induced changes in protein composition in developing grains of wheat are related to changes in total protein content. $J$. Exp. Bot. 2003, 54, 1731-1742.

Verma, D. P. S.; Zhang, C. S. Regulation of proline and arginine biosynthesis in plants. In Plant Amino Acids: Biochemistry and Biotechnology; Singh, B. K., Eds.; Marcel Dekker, NY, 1999; pp. 249-265. 


\title{
6 Effects of nitrogen fertilizer on pseudocereals seed composition
}

\begin{abstract}
The main aim of this study was to investigate the effect of nitrogen supply on seed composition of amaranth (Amaranthus spp.) and quinoa (Chenopodium quinoa Willd). The following compounds were analyzed: protein, fat, starch, total mineral, dietary fiber and pentosans contents. Fatty acid composition and pasting properties were also measured. The nitrogen fertilizer was applied with three different rates at $0,0.8$, and $1.2 \mathrm{~kg} \mathrm{~N} \mathrm{ha}^{-1}$, respectively. Seed protein was increased for $4 \% \mathrm{DM}$ while fat content was decreased for $1 \% \mathrm{DM}$ after nitrogen application. The nitrogen fertilizer treatment led to increased starch content from 460 to $481 \mathrm{~g}$ $\mathrm{kg}^{-1} \mathrm{DM}$ and decreased total mineral content from 36 to $34 \mathrm{~g} \mathrm{~kg}^{-1} \mathrm{DM}$, respectively. Dietary fiber and pentosans contents were significantly influenced by the cultivars. Amaranth contained higher concentrations of total dietary fiber (TDF) than quinoa. The ratio of insoluble dietary fiber (IDF) to soluble dietary fiber was about $2: 1$. Pentosans content in quinoa was higher than that of amaranth. Linoleic acid increased from 485.8 to 493.8 and $507.4 \mathrm{~g} \mathrm{~kg}^{-1}$ $\mathrm{DM}$ according to the increased rates of nitrogen fertilizer. A negative correlation between the applied fertilizer rate and the fatty acid composition was observed for stearic and oleic acid. Peak viscosity and pasting temperature were increased with rising nitrogen fertilizer rate. In addition, the protein contents of amaranth and quinoa were similar to that of wheat and oats.
\end{abstract}

Key words: amaranth; quinoa; protein; fat; dietary fiber; pasting properties

\subsection{Introduction}

Amaranth (Amaranthus spp.) and quinoa (Chenopodium quinoa Willd) are protein-rich pseudocereals. Their protein contents are higher than that of rice $(8 \% \mathrm{DM})$ and barley $(12 \%$ DM). The amino acid composition of the pseudocereal seed proteins corresponds rather to the FAO standards for the human nutrition than that of wheat and corn proteins (Ahamed et al., 1998).

Wild and cultivated amaranth and quinoa were at first cultivated by the Incas in South America and their grains were converted to food. Till now, both plants are particularly cultivated in Latin America and Asia where the protein sources are deficit. Meanwhile, they are also consumed in other regions of the earth, especially in European countries to improve the nutri- 
tional balance in the diet (Ahamed et al., 1998; National Research Council, 1989). Both plant types were found to differ in their grain protein content from 13 to $21 \% \mathrm{DM}$ and 12 to $19 \%$ DM respectively (Ahamed et al., 1998; National Research Council, 1989, Zhelenov et al., 1997). In addition, their fat contents were found similarly to that of other grain with a balanced spectrum of unsaturated fatty acids.

The influence of the nitrogen fertilization had an effect on the chemical composition of the seed (Bressani et al., 1987a). In different field experiments, the fat content of amaranth varied from 4.4 to $13.2 \% \mathrm{DM}$ and linoleic acid was identified as the dominant fatty acid $(24,7$ to $56.6 \%$ of the total fatty acid content) followed by oleic and palmitic acid (Prakash et al., 1995; Sauerbeck et al., 2002). The influence of nitrogen fertilizer on the yield was described (Elberi et al., 1993; National Research Council, 1989), however it did not have a distinctively effect on the fat content. The fat content of quinoa amounted from 3.8 to $9 \%$ DM. Linoleic acid with $52 \%$ was also the dominant fatty acid, followed by oleic acid with $24 \%$ (Ruales and Nair, 1993; Sauerbeck et al., 2002; Wood et al., 1993). The concentration of saturated fatty acids was $11 \%$ of the total fatty acid content, whereby palmitic acid with $8.5 \%$ was the main saturated fatty acid (Wood et al., 1993).

Dietary fiber is a heterogeneous mixture of polysaccharides and lignin that cannot be degraded by the endogenous enzymes of human. Fiber rich food has an increased protein-tocarbohydrate ratio. The protective effect of dietary fiber may be due to increased vegetable protein content, which may directly reduce clotting factors and oxidized LDL-cholesterol levels (Jenkins et al., 2000). Increasing dietary cereal fiber in the diet could contribute to the prevention of peripheral arterial disease (Merchant et al., 2003). Amaranth contained about 15.2 $\%$ of total dietary fiber (TDF) (USDA, 2003) and quinoa seed had $13.4 \%$ total dietary fiber, $11 \%$ insoluble dietary fiber (IDF) and 2.3\% soluble dietary fiber (SDF) (Ruales and Nair, 1994). Both of these plants had higher TDF and IDF than buckwheat, which contained 7\% TDF, 2.2\% IDF and 4.8\% SDF (Steadman et al., 2001). There are only few information's concerning the effects of nitrogen fertilizer on the nutritional properties of amaranth and quinoa available (Bressani, 1987a).

The goal of this investigation was to examine the effects of different plant genotypes and nitrogen fertilization levels on the chemical composition of amaranth and quinoa seeds. In this study, several parameters such as protein, fat, fatty acid, ash, dietary fiber, pentosans and pasting properties were determined. 


\subsection{Material and methods}

Plant materials were prepared as described in chapter 3.

Seed samples preparation, protein, fat, starch, total mineral, dietary fiber, pentosans contents and pasting properties were determined as described in chapter 3 .

\subsubsection{Fatty acid analysis}

The fatty acid composition was determined by GC following the procedure of Thies (1971), and analysed on a Perkin Elmer gas chromatograph mode 8600 (Perkin Elmer, USA) equipped with a fused-silica capillary column FFAP, $25 \mathrm{~m} \mathrm{x} 0.25 \mathrm{~mm}$ with $0.25 \mu \mathrm{mol}$ film thickness (Macherey and Nagel $\mathrm{GmbH}$, Germany). The oven, detector and injector temperatures were 210,230 and $230^{\circ} \mathrm{C}$ respectively. The carrier gas was hydrogen with a pressure of $100 \mathrm{kPa}$. The amount of $2 \mu \mathrm{l}$ of each sample was injected at a split rate of 1:70. Individual fatty acids including palmitic (16:0), stearic (18:0), oleic (18:1) and linoleic (18:2) acids were expressed as percentage of the total fatty acids, including minor fatty acids.

\subsection{Results and Discussions}

Amaranth and quinoa contained different protein and fat contents depending on their varieties (Table 6.1). The nitrogen fertilizer had significantly effects on seed protein and fat content. The seed protein increased from 108 to 137 and $151 \mathrm{~g} \mathrm{~kg}^{-1} \mathrm{DM}$ when applied 0, 0.8 and $1.2 \mathrm{~g}$ $\mathrm{N}_{\text {pot }^{-1}}$, respectively. Seed protein was increased for $4 \% \mathrm{DM}$, while fat content was decreased for $1 \% \mathrm{DM}$ with increased rates of nitrogen fertilizer. The decrease of fat content with the simultaneous increase of the protein content was also described in soybean (Hayati et al., 1996). The seed nitrogen accumulation depends on the genetic control of nitrogen uptake and utilization. Carbon is the source for seed proteins and fatty acids (Schwender and Ohlrogge, 2002). While amino acids are converted to seed storage proteins, they did not provide the carbon source for fatty acid synthesis. Approximately $30 \%$ of carbon in seed protein is derived from exogenous amino acids and as a consequence, the utilization of amino acids as a carbon source may have a significant influence on the total carbon and energy balance in the seed metabolism. Therefore, nitrogen fertilizer supply has a direct effect on the increase of seed storage proteins (Martre et al., 2003). 
Table 6.1 Effect of nitrogen fertilizer on seed composition $\left(\mathrm{g} \mathrm{kg}^{-1} \mathrm{DM}\right)$

\begin{tabular}{|c|c|c|c|c|c|c|c|c|c|}
\hline \multirow{2}{*}{$\begin{array}{l}\text { Plants } \\
\text { Species }\end{array}$} & \multirow[t]{2}{*}{ Varieties } & \multirow[t]{2}{*}{ Protein } & \multirow[t]{2}{*}{ Fat } & \multirow[t]{2}{*}{ Starch } & \multirow{2}{*}{$\begin{array}{c}\text { Total } \\
\text { Mineral }\end{array}$} & \multicolumn{3}{|c|}{ Dietary fiber } & \multirow[t]{2}{*}{ Pentosans } \\
\hline & & & & & & TDF & IDF & SDF & \\
\hline \multirow[t]{2}{*}{ Amaranth } & Bärnkraft & $131 b$ & $65 c$ & $451 \mathrm{a}$ & $36 b$ & $102 \mathrm{c}$ & $71 \mathrm{c}$ & 31 & $26 a$ \\
\hline & K432 & $135 d$ & $62 b$ & $504 c$ & $34 \mathrm{a}$ & $102 \mathrm{c}$ & $75 c$ & 27 & $28 \mathrm{a}$ \\
\hline \multirow[t]{2}{*}{ Quinoa } & Faro & $144 \mathrm{c}$ & $61 b$ & $447 \mathrm{a}$ & $37 b$ & $77 b$ & $51 b$ & 26 & $47 b$ \\
\hline & Tango & $122 \mathrm{a}$ & $58 \mathrm{a}$ & $488 b$ & $34 \mathrm{a}$ & $63 a$ & $41 \mathrm{a}$ & 23 & $49 b$ \\
\hline
\end{tabular}

Nitrogen levels $\left(\mathrm{g} \mathrm{N} \mathrm{pot}^{-1}\right)^{*}$

\begin{tabular}{ccccccccc}
\hline 0 & $108 \mathrm{a}$ & $68 \mathrm{c}$ & $460 \mathrm{a}$ & $36 \mathrm{~b}$ & 84 & 58 & 26 & 38 \\
0.8 & $137 \mathrm{~b}$ & $60 \mathrm{~b}$ & $477 \mathrm{~b}$ & $36 \mathrm{~b}$ & 88 & 58 & 30 & 37 \\
1.2 & $151 \mathrm{c}$ & $56 \mathrm{a}$ & $481 \mathrm{~b}$ & $34 \mathrm{a}$ & 86 & 62 & 24 & 38
\end{tabular}

The values of mean which are following by the same letter had $p>0.05$, and therefore, they were not characterized as significantly different

*Average values of all plant species and cultivars

The differences in the starch content between the cultivars were statistically significant. The starch content in quinoa was similar to the results of Ruales and Nair (1994), reporting that quinoa contained $516 \mathrm{~g} \mathrm{~kg}^{-1} \mathrm{DM}$. However, this value was lower than the previous results described by Mundigler (1998), who found in amaranth and quinoa flours 673 and $692 \mathrm{~g} \mathrm{~kg}^{-1}$ $\mathrm{DM}$, respectively. In this study, the starch content increased after nitrogen application (from 460 to 477 and $\left.481 \mathrm{~g} \mathrm{~kg}^{-1} \mathrm{DM}\right)$. The results showed also the positive correlation between protein and starch contents. The carbon assimilation is mainly used for the syntheses of starch and oil, and stored essentially in the endosperm or cotyledon. The decreasing of the fat content after nitrogen applications may be caused by the increased starch content due to the enlargement of the seed size (Triboï and Triboï-Blondel, 2002).

The total mineral content of amaranth and quinoa was also statistically significant depending on their varieties. The $1.2 \mathrm{~g} \mathrm{~N}_{\text {pot }}{ }^{-1}$ treatment caused the decrease of the total mineral content when compared with the other two treatments. The amaranth and quinoa contained higher total mineral contents ( 35.0 and $35.5 \mathrm{~g} \mathrm{~kg}^{-1} \mathrm{DM}$, respectively) than the cereals, i.e. $22,8.7$ and $6.7 \mathrm{~g} \mathrm{~kg}^{-1} \mathrm{DM}$ in buckwheat, rye, and wheat, respectively (Steadman et al., 2001; Verwimp et al., 2004). Singhal and Kulkarni (1988) also reported that Amaranthus species contained total mineral content in the range from 24.7 to $40 \mathrm{~g} \mathrm{~kg}^{-1} \mathrm{DM}$. 
Pentosans are components of the cell wall material and belong to the dietary fiber. Quinoa contained more pentosans than amaranth (48 and $27 \mathrm{~g} \mathrm{~kg}^{-1} \mathrm{DM}$, respectively), but the pentosan content was not changed after nitrogen application. In amaranth and quinoa we found lower concentrations than Hansen et al. (2003) reported in their study. They gave values of about 80 to $121 \mathrm{~g} \mathrm{~kg}^{-1} \mathrm{DM}$ as the sum of arabinose and xylose.

In the present study, the dietary fiber content was not affected by nitrogen application. It was depending on plant genetics and varieties (Table 6.1). The total and insoluble dietary fiber contents of amaranth were higher than that of quinoa. Amaranth contained $102 \mathrm{~g} \mathrm{~kg}^{-1} \mathrm{DM}$ TDF, while quinoa contained $70 \mathrm{~g} \mathrm{~kg}^{-1} \mathrm{DM}$. The insoluble dietary fiber was the major part of seed dietary fiber. The ratio of IDF : SDF of all treatments was about $2: 1$. This ratio is in agreement with Ruales and Nair (1994), however, the dietary fiber content was lower than that reported as $134 \mathrm{~g} \mathrm{~kg}^{-1} \mathrm{DM}$ with the same determination method. This finding may be caused from the use of different quinoa varieties.

The cultivars had significant differences in their fatty acid contents (Table 6.2). Oleic and linoleic acids were the major unsaturated acids both in amaranth and quinoa, whereas palmitic was the main saturated fatty acid. Amaranth contained higher palmitic and oleic acid concentrations with 188.8 and $281.8 \mathrm{~g} \mathrm{~kg}^{-1} \mathrm{DM}$, while quinoa contained only 123.0 and $197.2 \mathrm{~g} \mathrm{~kg}^{-1}$ $\mathrm{DM}$, respectively. The linoleic acid content in quinoa was higher than in amaranth (560 and $430 \mathrm{~g} \mathrm{~kg}^{-1} \mathrm{DM}$, respectively). This result was similar to Bressani et al. (1987b), Prakash and Pal (1992), Prakash et al. (1995). 


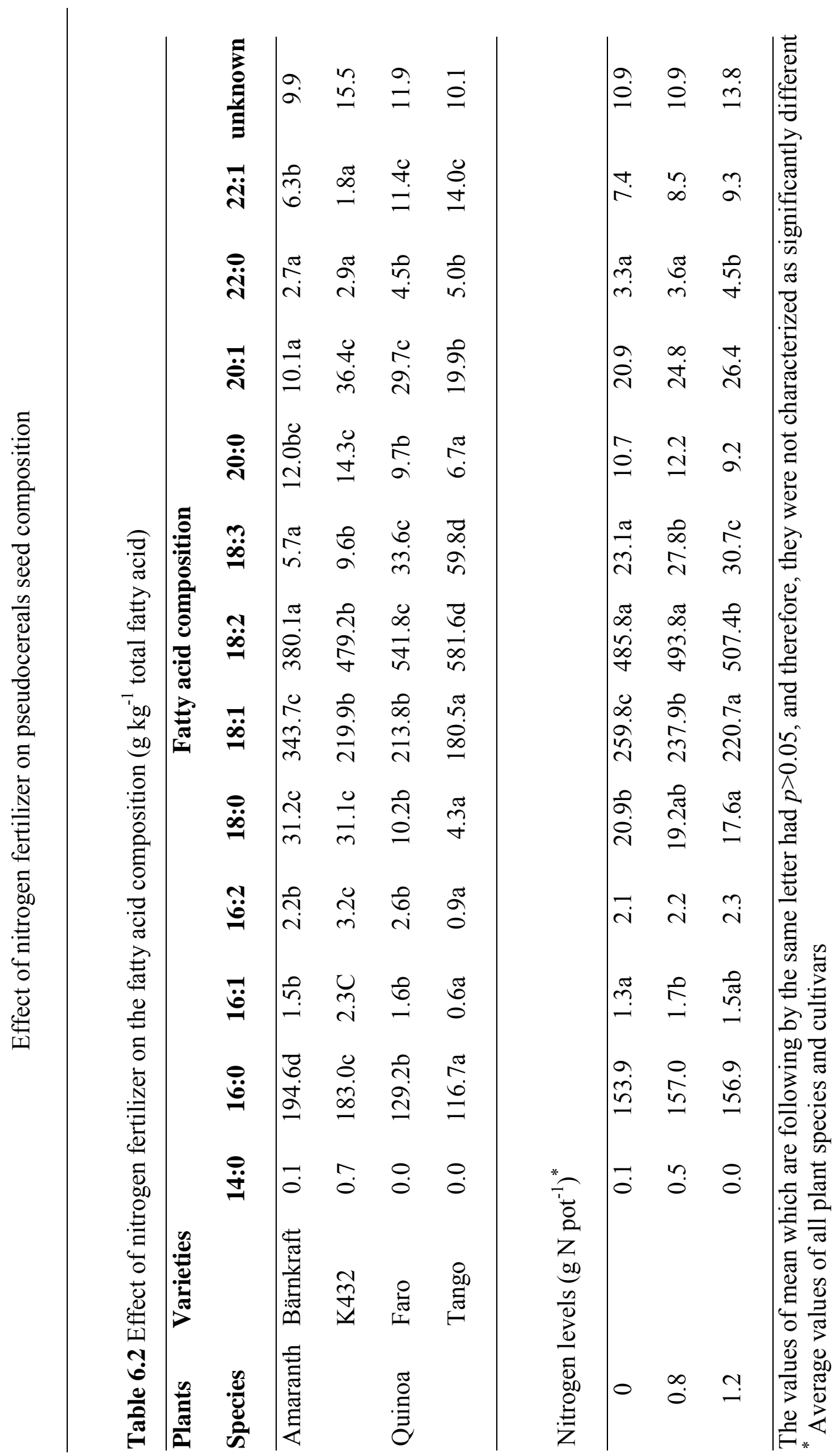


The effect of nitrogen supply on fatty acid composition was clearly demonstrated. The fatty acid composition and particulary the contents of stearic, oleic and linoleic acid were changed. The contents of stearic and oleic acid were decreased with increasing rates of nitrogen supply, while the linoleic acid content was increased. The fatty acids synthesis was involved and activated by specific enzymes, which elongate chain lengths and introduced additional double bonds (Ohlrogge, 1994). This result can be explained by an indirect influence of the nitrogen supply on the availability of other nutrients.

An increase in the linoleic acid content as essential fatty acid appears on the one hand interesting in nourish-physiological regard while on the other hand it increase the offflavours when the oil is used for cooking (John, 1992). The stearic, $\alpha$-Linoleic and arachidic acid contents were significant affected by nitrogen supply.

Table 6.3 Effect of nitrogen fertilizer on pasting properties of amaranth and quinoa seed flour (cP)

\begin{tabular}{llccccc}
\hline $\begin{array}{l}\text { Plants } \\
\text { Species }\end{array}$ & Varieties & $\begin{array}{c}\text { Peak } \\
\text { viscosity }\end{array}$ & Breakdown & Setback & $\begin{array}{c}\text { Final } \\
\text { viscosity }\end{array}$ & $\begin{array}{c}\text { Pasting } \\
\text { temp. }\left({ }^{\mathbf{0}} \mathbf{C}\right)\end{array}$ \\
\hline Amaranth & Bärnkraft & $1465 \mathrm{~d}$ & $260 \mathrm{~b}$ & $207 \mathrm{~b}$ & $1449 \mathrm{~b}$ & $78.22 \mathrm{c}$ \\
& K432 & $1109 \mathrm{a}$ & $89 \mathrm{a}$ & $144 \mathrm{a}$ & $1148 \mathrm{a}$ & $76.50 \mathrm{~b}$ \\
Quinoa & Faro & $1386 \mathrm{c}$ & $48 \mathrm{a}$ & $454 \mathrm{~d}$ & $1792 \mathrm{~d}$ & $72.66 \mathrm{a}$ \\
& Tango & $1218 \mathrm{~b}$ & $17 \mathrm{a}$ & $360 \mathrm{c}$ & $1561 \mathrm{c}$ & $73.31 \mathrm{a}$ \\
\hline
\end{tabular}

Nitrogen levels (g N pot $\left.{ }^{-1}\right)^{*}$

\begin{tabular}{cccccc}
\hline 0 & $1208 \mathrm{a}$ & 106 & 280 & $1397 \mathrm{a}$ & $74.61 \mathrm{a}$ \\
0.8 & $1368 \mathrm{~b}$ & 105 & 292 & $1566 \mathrm{~b}$ & $74.96 \mathrm{ab}$ \\
1.2 & $1307 \mathrm{~b}$ & 100 & 303 & $1499 \mathrm{~b}$ & $75.95 \mathrm{~b}$ \\
\hline
\end{tabular}

The values of mean which are following by the same letter had $p>0.05$, and therefore, they were not characterized as significantly different

* Average of all plant species and cultivars

The pasting characteristics of amaranth and quinoa flour were shown in Table 6.3 Significant differences between the cultivars were observed. Amaranth had higher pasting temperature than quinoa. 


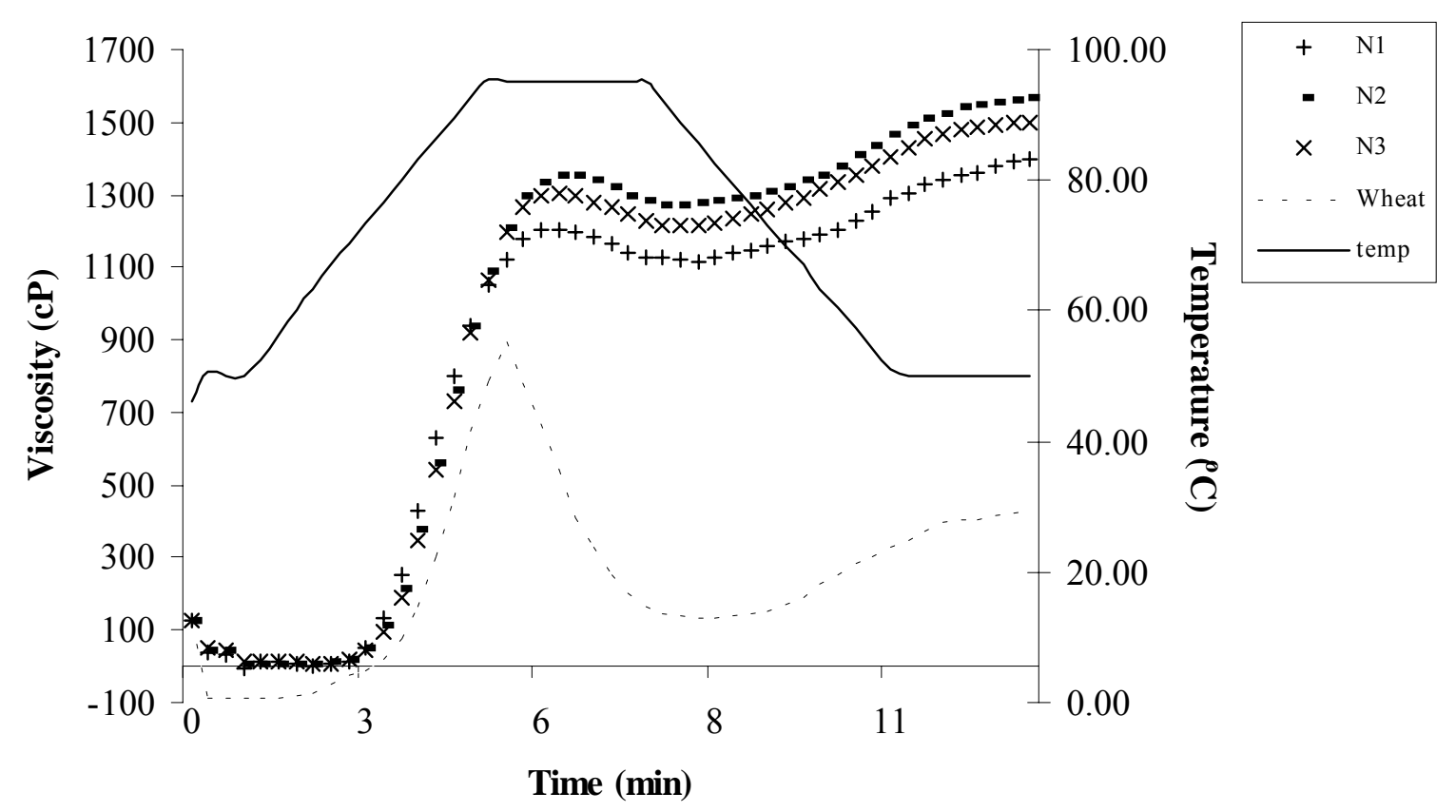

Figure 6.1 Pasting characteristics of amaranth and quinoa flours supplied with different rates of nitrogen application and compared with wheat flour (N1, N2, and N3 were $0,0.8$, and $1.2 \mathrm{~g} \mathrm{~N} \operatorname{pot}^{-1}$, respectively)

Effect of nitrogen fertilizer on pasting properties is shown in Figure 1. In all cultivars, peak viscosity, final viscosity and pasting temperature were significantly increased after nitrogen application. Zhou et al. (1998) found in oat flour that the application of nitrogen fertilizer decreased the peak viscosity, while the pasting temperature was increased. A high pasting temperature expected to be a disadvantage during processing because insufficient gelatinisation may occur during short processing times used commercially.

The protein, fat, total mineral and pentosans contents in this experiment were in the same range with the results described in chapter 3 . However, starch and dietary fiber contents were lower than the results in chapter 3. Plant production environment and crop management could be of important influence on this result. 


\subsection{Conclusions}

The differences of plant genotypes and the nitrogen fertilizer application levels influenced the chemical composition of the seeds. Nitrogen supply had effects on protein, fat, starch, total mineral content and pasting properties. Palmitic, oleic and linoleic acid were the major fatty acids and were influenced by applied nitrogen fertilizer. Linoleic acid content was increased proportionally to the nitrogen rates. The dietary fiber and pentosans contents were not changed. Nitrogen fertilization had effects on the increase of the nutritional values of amaranth and quinoa seeds. However, it affected the processing quality by increasing the pasting temperature. For the processing of products, the optimum rates of nitrogen fertilizer application should be firstly determined to avoid undesirable effects, that may occurred during the processing procedures. Especially high pasting temperatures requirement for the gelatinisation may increase the cost of production.

\subsection{References}

Ahamed NT, Singhal RS, Kulkarni PR, Pal M, A lesser-known grain, Chenopodium quinoa: Review of the chemical composition of its edible parts. Food and Nutr Bull 19:61-70 (1998).

Aufhammer W, Kaul HP, Herz P, Nalborezyk E, Dalbiak A, Gontarczyk M, Grain yield formation and nitrogen uptake of amaranth. Eur J Agron 4:379-386 (1995).

Bressani R, Gonzalez JM, Elias LG, Melgar M, Effect of fertilizer application on the yield, protein and fat content, and protein quality of raw and cooked grain of three amaranth species. Plant Food Hum Nutr 37:59-67 (1987a).

Bressani R, Gonzalez JM, Zuniga J. Breuner M, Elias LG, Yield, selected chemical composition and nutritive value of 14 selections og amaranth grain representing four species. J Sci Foof Agri 38:347-356 (1987b).

Elbehri A, Putnam DH, Schmitt M, Nitrogen fertilizer and cultivar effects on yield and nitrogen-use efficiency of grain amaranth. Agron J 85:120-128 (1993).

Hansen HB, Rasmussen CV, Bach Knudsen KE, Hansen A, Effects of genotype and harvest year on contents and composition of dietary fibre in rye (Secale cereale L) grain. J Sci Food Agri 83:76-85 (2003).

Hayati R, Egli DB, Crafts-Brandner SJ, Independence of nitrogen supply and seed growth in soybeans: studies using an in vitro culture system. $J$ Exp Bot 47:33-40 (1996).

Jenkins DJA, Axelsen M, Kendall CWC, Augustin LSA, Vuksan V, Smith U, Dietary fibre, lente carbohydrates and the insulin-resistant diseases. Brit J Nutr 83: S157S163 (2000).

John P, Oils in Biosynthesis of the major crop products, Ed by John P, John Wiley \& Sons Ltd, Baffins Lane, Chichester, England, pp 88-113 (1992). 
Martre P, Porter JR, Jamieson PD, Triboï E, Modeling Grain Nitrogen Accumulation and Protein Composition to Understand the Sink/Source Regulations of Nitrogen Remobilization for Wheat. Plant Physiol 133:1959-1967 (2003).

Merchant AT, Hu FB, Spiegelman D, Willett WC, Rimm EB, Ascherio A, Dietary fiber reduces peripheral arterial disease risk in men. J Nutr 133:3658-3663 (2003).

Mundigler N, Isolation and determination of starch from amaranth (Amaranthus cruentus) and quinoa (Chendopodium quinoa). Starch/Stärke 50:67-69 (1998).

National Research Council, Kiwicha an quinoa, in Lost Crops of the Incas: Littleknown Plants of the Andes with Promise for worldwide Cultivation, National Academy Press, Washington, DC, pp 139-161 (1989).

Ohlrogge JB, Design of new plant productions: engineering of fatty acid metabolism. Plant physiol 104:821-826 (1994).

Prakash D, Pal M, Seed protein, fat and fatty acid profile of Amaranthus species. J Sci Food Agri 58:145-147 (1992).

Prakash D, Joshi BD, Pal M, Vitamin C in leaves and seed oil composition of the Amaranthus species. Inter J Food Sci and Nutr 46:47-51 (1995).

Ruales J, Nair BM, Contents of fat, vitamins and minerals in quinoa (Chenopodium quinoa willd.) seed. Food Chem 48:131-137 (1993).

Ruales J, Nair BM, Properties of starch and dietary fibre in raw and processed quinoa (Chenopodium quinoa willd.) seeds. Plant Food Hum Nutr 45:223-246 (1994).

Sauerbeck G, Stolzenburg K, Schweiger P, Schroeter C, Wilhelm E, Matthaeus B, Anbau von Amaranth und Quinoa in Norddeutschland: Kornqualitaet am Beispiel von Fettuntersuchungen. Getreide, Mehl und Brot 56:330-333 (2002).

Schwender J, Ohlrogge JB, Probing in Vivo Metabolism by Stable Isotope Labeling of Storage Lipids and Proteins in Developing Brassica napus Embryos. Plant Physiol 130:347-361 (2002).

Singhal R and Kulkarni PR, Composition of the seeds of some Amaranthus species. $J$ Sci Food Agri 42:325-331 (1988).

Steadman KJ, Burgoon MS, Lewis BA, Edwardson SE, Obendorf RL, Buckwheat Seed Milling Fractions: Description, Macronutrient Composition and Dietary Fibre. J Cereal Sci 33:271-278 (2001).

Thies W, Schnelle und einfache Analysen der Fettsaeurezusammensetzung in einzelnen Rapskotyledonen. I.Gaschromatografische und papierchromatografische Methoden. Z. Pflanzenzuechtung 65:181-202 (1971).

Triboï E and Triboï-Blondel AM, Productivity and grain or seed composition: a new approach to an old problem. Eur J Agron 16:163-186 (2002).

USDA, Amaranth. Food Group 20 Cereal Grains and Pasta. USDA Nutrient Database for Standard Reference, Release 16. pp 1-2 (2003).

Verwimp T, Vandeputte GE, Marrant K, Delcour JA, Isolation and characterisation of rye starch. J Cereal Sci 39:85-90 (2004).

Wood SG, Lawson LD, Fairbanks DJ, Robinson LR, Anderson WR, Seed lipid content and fatty acid composition of three quinoa cultivars. J Food Comp Anal 6:4144 (1993).

Zhelenov AV, Solonenko LP, Zheleznova NB, Seed proteins of the wild and the cultivated Amaranthus species. Euphytica 97:177-182 (1997).

Zhou MX, Roberts GL, Robards K, Glennie-Holmes M. Effects of sowing date, nitrogen application and sowing rate on oat quality. Aust J Agri Res 49:845-852 (1998). 


\section{Summary}

Soybean and peanut proteins are among the most common food allergens for children. Moreover, peanut protein is among the most common allergens for adults (Sampson, 1998). Wheat and other cereal grains such as rice, maize and barley are well known causes of food allergies (Nakamura, 1987). These allergens were not observed in amaranth (Amaranthus spp.) and quinoa (Chenopodium quinoa Willd). Therefore, these plant species may be used as an alternative source for gluten-free diets (Kuhn et al., 1996). Furthermore, amaranth and quinoa contained high amounts of dietary fiber, which takes part in lipid metabolism improvement and prevention of LDL-C oxidation (Kreft et al., 1998).

Seed composition of amaranth and quinoa varieties produced under Northern Germany conditions in 2001 and 2002 were investigated. The variation in seed composition of amaranth and quinoa was caused by interactions between genetic and environmental factors. The variation in protein content was mainly affected by the planting season. Amaranth and quinoa seeds contained high protein contents. Their amino acid contents were accepted as sufficient for the human nutritional requirements. The proteins were especially rich in lysine. The fat and starch contents were mainly affected by the varieties. The amaranth varieties contained higher starch and lower pentosans contents than the quinoa varieties. The insoluble dietary fiber was the main part of the dietary fiber content in the seed. This is of great importance for the nutritional value of pseudocereals, because a high content of dietary fiber has positive effects on the reduction of the cancer risk. In general, amaranth and quinoa contained higher total mineral contents than the other cereals such as rye and wheat. The pasting properties of amaranth and quinoa flour were very different from that of wheat flour. Amaranth flour had more gel formation ability and viscosity than wheat flour. However, breeding programs should be considered to improve the agronomic characters for obtaining more stable lines of chemical composition.

To study the effects of nitrogen fertilizer on biomass, grain yields, nitrogen uptake and its assimilation from the soil to the vegetative and grain parts of amaranth and quinoa plants were investigated. Nitrogen fertilizer application affected the increases of grain weight, biomass, grain yield and harvest index. Quinoa had higher grain yield 
and harvest index than amaranth. Nitrogen accumulations in plant and grain were correlated with the nitrogen fertilizer application. Nitrogen use efficiency, nitrogen utilization efficiency, nitrogen harvest index and grain yield per unit of grain nitrogen decreased with increased nitrogen fertilizer rates. Higher rates of nitrogen fertilizer than $0.8 \mathrm{~g} \mathrm{~N} \mathrm{pot}^{-1}$ had no effect on the increase of the nitrogen uptake efficiency. Quinoa had a higher efficiency in producing grain per unit of plant nitrogen than amaranth (NUtE). However, the NUtE was decreased to 36 and $50 \%$ after application of 0.8 and $1.2 \mathrm{~g} \mathrm{~N}$ pot $^{-1}$, respectively. The present results show a demand for breeding programs to improve the nitrogen utilization efficiency and nitrogen uptake efficiency in pseudocereals.

The nutritional values of amaranth and quinoa are mainly correlated with their protein and amino acid composition. Nitrogen supply was the dominant factor on the protein accumulation in the seed. Effects of nitrogen fertilizer on protein properties of amaranth and quinoa were observed. The concentrations of Albu, Glob and Glut in amaranth and quinoa as well as their amino acid compositions were determined. Nitrogen fertilizer application affected both protein fractions and amino acid composition. Decreasing of Albu-1 fraction was correlated with the increasing of Glob fractions and should be affected during seed development stage. Protein patterns depended on the species of crop plants. The contents of essential amino acids were not affected by nitrogen fertilizer application. Amaranth and quinoa had high contents of Lys, but low contents of Met. Quinoa contained more Leu and Val contents than amaranth. Albu-1 fractions had high Lys content, while Albu-2 fractions had high Leu content. Glob fractions contained higher concentrations of essential amino acids than the other fractions, but lower content of Lys. Glut fractions were well balanced in their essential amino acids with exception of Met. For human diet, nitrogen fertilizer application should be advantage for improve the nutritional values by increased protein content and maintained amounts of essential amino acid content.

Nitrogen supply affected the protein and fat content of the seeds. Palmitic, oleic and li noleic acid were the major fatty acids and their concentrations were influenced by the rates of nitrogen fertilizer. Linoleic acid content increased proportionally to the nitrogen fertilizer application. A considerable content of linoleic acid as an unsaturated essential fatty acid is a good parameter giving for the quality of oil using for human 
diet. The dietary fiber and pentosans contents were not changed, whereas the increase of the pasting temperature of flours obtained from amaranth and quinoa seeds was negatively related to the nitrogen supply.

Finally, the obtained results about the content of essential and nonessential nutrients showed the high potential of amaranth and quinoa seeds in human diet utilization. Nitrogen fertilizer application affected the increase of seed protein and linoleic acid content but decreased Albu-1 fractions. The dietary fiber content was not affected by nitrogen fertilizer application. For the processing of products, the optimum rates of nitrogen fertilizer application should be firstly determined to avoid undesirable effects, that may occurred during the processing procedures. Especially high pasting temperatures requirement for the gelatinisation may increase the cost of production. 


\section{Zusammenfassung}

Sojabohnen- und Erdnussproteine zählen zu den häufigsten allergieauslösenden Verbindungen bei Kindern, während Erwachsene vor allem unter Allergien leiden, die von Erdnussproteinen hervorgerufen werden (Sampson, 1998). Weizen und andere Getreidearten wie Reis, Mais und Gerste sind weitere bekannte Ursachen für Nahrungsmittelallergien (Nakamura, 1987). Diese Allergene wurden jedoch nicht in Amarant (Amarant spp.) und Reismelde (Chenopodium quinoa Willd) gefunden. Folglich können diese Pseudocerealien potentiell als alternative Quelle für glutenfreie Diäten (Kuhn et al., 1996) genutzt werden. Außerdem enthalten Amarant und Reismelde hohe Mengen an Ballaststoffen, die an der Verbesserung des Fettstoffwechsels und an der Verhinderung der LDL-C Oxidation beteiligt sind (Kreft et al., 1998).

Im Rahmen der vorliegenden Arbeit wurden zunächst mehrere Amarant- und Reismeldesorten unterschiedlicher Herkünfte hinsichtlich ihrer chemischen Zusammensetzung untersucht, welche in den Jahren 2001 und 2002 unter den Bedingungen Norddeutschlands angebaut worden waren. Die Veränderung der Samenszusammensetzung von Amarant und Reismelde wurde überwiegend durch Interaktionen zwischen genetischen Faktoren und Klimaeinflüssen verursacht. Veränderungen im Proteingehalt wurde dagegen primär von der Anbausaison beeinflusst. Die ermittelte Aminosäurezusammensetzung entspricht den Anforderungen, die aus Sicht der menschlichen Ernährung insbesondere an den Gehalt essentieller Aminosäuren zu stellen sind. Die Proteine der untersuchten Pseudocerealien waren vor allem reich an Lysin. Fett- und Stärkegehalte wurden hauptsächlich von dem Potential der jeweiligen Sorte beeinflusst, wobei Amarant höhere Stärke- und geringere Pentosangehalte als Reismelde enthielt. Die Ballaststoffe bestanden hauptsächlich aus unlöslichen Verbindungen. Dies ist von großer Bedeutung für den Nährwert von Pseudocerealien, weil ein hoher Inhalt an Ballaststoffen positive Effekte auf die Verminderung des kanzerogenen Risikos hat. Im Allgemeinen wiesen Amarant und Reismelde einen höheren Gehalt an Mineralstoffen als z.B. Roggen und Weizen auf. Im Hinblick auf die Viskosität unterschieden sich die Mehle aus Amarant und Reismelde sehr deutlich von Weizenmehl. Amarantmehl zeigte eine bessere Ausprägung von Gelbildung und Viskosität. Im Hinblick auf weitere Züchtungsarbeiten sollte aus Sicht der ernährungsphysiologischen Qualität sowie der Verarbeitungseigenschaften mehr Augenmerk auf eine Stabilisierung der Zusammensetzung an wertgebenden Inhaltsstoffe gelegt werden. 
Um den Einfluss der Stickstoffdüngung auf Biomasse, Kornertrag, Stickstoffaufnahme und dessen Assimilation vom Boden zu den vegetativen Teilen und Körnern von Amarant und Reismelde zu untersuchen, wurden die Pflanzen analysiert. Die Stickstoffzufuhr bewirkte Zunahmen des Korngewichts, der Biomasse, des Kornertrages und des HI. Reismelde hatte hö here Kornerträge und einen höheren HI als Amarant. Die Stickstoffakkumulation in der Pflanze und im Korn war von der Höhe der N-Düngung abhängig. Die Parameter Stickstoffaufnahmeeffizienz, Stickstoffverwertungseffizienz, Stickstoffernteindex und Kornertrag pro Maßeinheit des Kornstickstoffes verringerten sich mit zunehmender Stickstoffdünger-Zufuhr. Höhere Raten als $0.8 \mathrm{~g} \mathrm{~N}$ Gefä $\beta^{-1}$ hatten keinen Einfluss auf die Zunahme der Stickstoffaufnahmeeffizienz. Reismelde hatte eine höhere Stickstoffverwertungseffizienz als Amarant, die jedoch um 6 bzw. 50 \% nach Anwendung von 0.8 und $1.2 \mathrm{~g} \mathrm{~N}$ Gefäß ${ }^{-1}$ verringert wurde. Die ermittelten Resultate belegen die Notwendigkeit der züchterischen Verbesserung der Stickstoffaufnahme- und verwertungseffizienz in Pseudocerealien.

Der Nährwert von Amarant und Reismelde wird hauptsächlich durch ihre Protein- und Aminosäurezusammensetzung bestimmt. Das Stickstoffangebot war dominierend in Bezug auf die Proteinakkumulation im Samen. Effekte der Stickstoffdüngung auf die Proteineigenschaften Amarant und Reismelde wurden ebenfalls beobachtet. Die Höhe der Stickstoffzufuhr beeinflusste den mengenmäßigen Anteil der untersuchten Proteinfraktionen und die Aminosäurezusammensetzung. Während die Fraktion von Albu-1 abnahm, erfolgte eine Zunahme der Glob- Fraktion. Die Gesamtkonzentrationen an essentiellen Aminosäuren wurden nicht durch die Stickstoffdüngung beeinflusst. Amarant und Reismelde hatten hohe Gehalte an Lys und niedrige Gehalte an Met. Reismelde enthielt höhere Leu- und Val-Gehalte als Amarant. Die Fraktion von Albu-1 hatte einen hohen Lys-Gehalt, während Albu-2 vor allem durch einen hohen Leu-Gehalt charakterisiert war. Die Glob-Fraktion enthielt höhere Mengen an essentiellen Aminosäuren als alle anderen Fraktionen, jedoch einen niedrigeren Gehalt an Lys. Die Glut-Fraktionen wiesen mit Ausnahme von Met eine ausgeglichene Zusammensetzung an essentiellen Aminosäuren auf. Im Hinblick auf die Erfordernisse bei der menschlichen Ernährung erwies sich die Stickstoffdüngung von Vorteil für die Verbesserung der Nährwerte durch erhöhte Proteingehalte und gleich bleibende Aminosäuregehalte. Die Stickstoff-Versorgung beeinflusste auch den Lipidgehalt der Samen. Palmitin-, Ölsäure- und Linolsäure wurden als dominierende Fettsäuren identifiziert. Ihre Gehalte wurden durch die Höhe der Stickstoffdüngung beeinflusst. Der Linolsäuregehalt erhöhte sich proportional zur 
Stickstoffzufuhr. Ein hoher Gehalt an Linolsäure als ungesättigte Fettsäure ist ein guter Parameter für die Ölqualität im Hinblick auf die menschliche Ernährung. Der Gehalt an Ballaststoffen, einschließlich der Pentosane wurde nicht von der Stickstoffdüngung bestimmt. Dagegen korrelierte die Zunahme der Verkleisterungstemperaturen der Mehle von Amarant und Reismelde negativ mit der Höhe der Stickstoffzufuhr.

Schließlich zeigten die erreichten Resultate hinsichtlich des Gehaltes an ernährungsphysiologisch relevanten Nährstoffen das hohe Potential von Amarant und Reismelde in der menschlichen Ernährung. Die Stickstoffdüngung beeinflusste die Zunahme des Proteins in den Körnern und den Linolsäuregehalt. Gleichzeitig verringerte sich die Albu1-Fraktion. Im Hinblick auf die Verarbeitungseigenschaften von Mehlen aus Pseudocerealien sollte die optimale Rate der Stickstoffdüngung festgestellt werden, um unerwünschte Effekte und erhöhte Kosten infolge hoher Verkleisterungstemperaturen zu vermeiden. 
Appendix I: Grain yield, nitrogen accumulated in grain at harvest, nitrogen use efficiency and grain yield per unit of grain nitrogen of amaranth and quinoa applied with three different rates of nitrogen fertilizer in 2001. [ $\mathrm{Ng}=$ nitrogen accumulated in grain at harvest $\left(\mathrm{g} \mathrm{N}_{\text {grain }}\right)$, NUE = Nitrogen use efficiency (g grain $\mathrm{g}^{-1} \mathrm{~N}_{\text {min }}$ ), GNE = grain produced per unit of grain nitrogen $\left(\mathrm{g}_{\text {grain }} \mathrm{g}^{-1} \mathrm{~N}_{\text {grain }}\right)$ ]

\begin{tabular}{llrrrrr}
\hline $\begin{array}{l}\text { Plants } \\
\text { Species }\end{array}$ & Varieties & $\begin{array}{c}\text { Nitrogen levels } \\
\left(\mathrm{g} \mathrm{N} \mathrm{pot}^{-1}\right)\end{array}$ & $\begin{array}{c}\text { Grain yield } \\
\left(\mathrm{g} \mathrm{plant}^{-1}\right)\end{array}$ & $\mathrm{Ng}$ & $\mathrm{NUE}$ & GNE \\
\hline Amaranth & Bärnkraft & 0.0 & 2.29 & 0.05 & 22.88 & 50.04 \\
& & 0.8 & 2.48 & 0.07 & 4.97 & 38.03 \\
& \multirow{2}{*}{ K432 } & 1.2 & 2.62 & 0.07 & 3.75 & 36.97 \\
& & 0.0 & 2.15 & 0.05 & 21.51 & 43.99 \\
& & 0.8 & 3.26 & 0.09 & 6.52 & 36.83 \\
Quinoa & Faro & 1.2 & 3.41 & 0.10 & 4.87 & 34.07 \\
& & 0.0 & 2.37 & 0.05 & 23.68 & 48.22 \\
& & 0.8 & 2.77 & 0.07 & 5.55 & 38.12 \\
& Tango & 1.2 & 2.37 & 0.07 & 3.39 & 34.24 \\
& & 0.0 & 4.07 & 0.07 & 40.65 & 58.17 \\
& & 0.8 & 6.48 & 0.16 & 12.96 & 39.74 \\
& & 1.2 & 6.54 & 0.17 & 9.34 & 38.40 \\
\hline
\end{tabular}

Appendix II: Agronomic characteristics, biomass, grain yield, harvest index (HI), nitrogen accumulated in grain at harvest, total aboveground plant nitrogen of amaranth and quinoa applied with three different rates of nitrogen fertilizer in 2002. [TKW= Thousand-Kernel Weight, $\mathrm{Ng}=$ nitrogen accumulated in grain at harvest per plant $\left(\mathrm{g} \mathrm{N}_{\text {grain }}\right), \mathrm{Nt}=$ total aboveground plant nitrogen $\left.\left(\mathrm{g} \mathrm{N}_{\text {plant }}\right)\right]$

\begin{tabular}{|c|c|c|c|c|c|c|c|c|c|}
\hline $\begin{array}{l}\text { Plants } \\
\text { Species }\end{array}$ & Varieties & $\begin{array}{c}\text { Nitrogen } \\
\text { levels } \\
\left(\mathrm{g} \mathrm{N} \mathrm{pot}^{-1}\right)\end{array}$ & $\begin{array}{l}\text { Plant } \\
\text { height } \\
(\mathrm{cm})\end{array}$ & $\begin{array}{c}\text { Biomass } \\
\left(\text { g plant }^{-1}\right)\end{array}$ & $\begin{array}{l}\text { Grain yield } \\
\left(\text { g plant }^{-1}\right)\end{array}$ & $\begin{array}{c}\text { TKW } \\
(\mathrm{g})\end{array}$ & $\mathrm{HI}$ & $\mathrm{Ng}$ & $\mathrm{Nt}$ \\
\hline \multirow[t]{6}{*}{ Amaranth } & Bärnkraft & 0.0 & 61 & 7.07 & 1.53 & 0.68 & 0.22 & 0.03 & 0.06 \\
\hline & & 0.8 & 112 & 34.83 & 6.31 & 0.77 & 0.18 & 0.12 & 0.45 \\
\hline & & 1.2 & 111 & 41.87 & 9.50 & 0.83 & 0.23 & 0.22 & 0.72 \\
\hline & K432 & 0.0 & 66 & 9.80 & 1.87 & 0.62 & 0.19 & 0.04 & 0.08 \\
\hline & & 0.8 & 77 & 29.55 & 5.78 & 0.60 & 0.20 & 0.13 & 0.40 \\
\hline & & 1.2 & 76 & 29.38 & 5.52 & 0.58 & 0.19 & 0.13 & 0.52 \\
\hline \multirow[t]{6}{*}{ Quinoa } & Faro & 0.0 & 106 & 9.31 & 2.41 & 2.22 & 0.26 & 0.04 & 0.06 \\
\hline & & 0.8 & 147 & 28.14 & 8.14 & 2.64 & 0.29 & 0.17 & 0.31 \\
\hline & & 1.2 & 132 & 33.04 & 10.17 & 2.75 & 0.31 & 0.25 & 0.54 \\
\hline & Tango & 0.0 & 91 & 9.72 & 2.84 & 2.81 & 0.29 & 0.04 & 0.07 \\
\hline & & 0.8 & 122 & 30.97 & 11.03 & 3.06 & 0.36 & 0.22 & 0.40 \\
\hline & & 1.2 & 126 & 36.38 & 13.39 & 2.63 & 0.37 & 0.32 & 0.62 \\
\hline
\end{tabular}


Appendix III: Nitrogen use efficiency and components of nitrogen efficiency of amaranth and quinoa applied with three rates of nitrogen fertilizer in 2002. [NUE $=$ Nitrogen use efficiency $\left(\mathrm{g}_{\text {grain }} \mathrm{g}^{-1}\right.$ $\mathrm{N}_{\text {min }}$ ), NUpE = nitrogen uptake efficiency $\left(\mathrm{g} \mathrm{N}_{\text {plant }} \mathrm{g}^{-1} \mathrm{~N}_{\text {min }}\right)$, NUtE = nitrogen utilization efficiency $(\mathrm{g}$ grain $\left.\mathrm{g}^{-1} \mathrm{~N}_{\text {plant }}\right)$, NHI = nitrogen harvest index $\left(\mathrm{g} \mathrm{N}_{\text {grain }} \mathrm{g}^{-1} \mathrm{~N}_{\text {plant }}\right.$, GNE $=$ grain produced per unit of grain nitrogen (g grain $\mathrm{g}^{-1} \mathrm{~N}_{\text {grain }}$ ]

\begin{tabular}{llcccccc}
\hline $\begin{array}{l}\text { Plant } \\
\text { Species }\end{array}$ & Varieties & $\begin{array}{c}\text { Nitrogen } \\
\text { levels } \\
\left(\mathrm{g} \mathrm{N} \mathrm{pot}^{-1}\right)\end{array}$ & NUE & NUpE & NUtE & NHI & GNE \\
\hline Amaranth & Bärnkraft & 0.0 & 15.33 & 0.61 & 25.13 & 0.46 & 55.15 \\
& & 0.8 & 12.63 & 0.91 & 13.88 & 0.27 & 51.81 \\
& & 1.2 & 13.58 & 1.03 & 13.16 & 0.31 & 43.10 \\
& \multirow{2}{*}{ K432 } & 0.0 & 18.69 & 0.76 & 24.45 & 0.47 & 52.36 \\
& & 0.8 & 11.55 & 0.80 & 14.41 & 0.33 & 43.99 \\
& & 1.2 & 7.89 & 0.74 & 10.68 & 0.25 & 42.02 \\
& & 0.0 & 24.12 & 0.60 & 40.06 & 0.65 & 61.22 \\
& & 0.8 & 16.27 & 0.63 & 25.85 & 0.55 & 46.58 \\
& & 1.2 & 14.53 & 0.77 & 18.79 & 0.45 & 41.32 \\
& & 0.0 & 28.42 & 0.73 & 39.04 & 0.53 & 73.89 \\
& \multirow{2}{*}{ Tango } & 0.8 & 22.05 & 0.80 & 27.61 & 0.54 & 51.28 \\
& & 1.2 & 19.13 & 0.88 & 21.62 & 0.51 & 42.19 \\
\hline
\end{tabular}

Appendix IV: Effect of nitrogen fertilizer on seed protein fractions

\begin{tabular}{|c|c|c|c|c|c|c|c|}
\hline \multirow{2}{*}{$\begin{array}{l}\text { Plants } \\
\text { Species }\end{array}$} & \multirow[t]{2}{*}{ Varieties } & \multirow{2}{*}{$\begin{array}{c}\text { Nitrogen } \\
\text { levels } \\
\left(\mathrm{g} \mathrm{N} \mathrm{pot}^{-1}\right)\end{array}$} & \multicolumn{5}{|c|}{ Fraction (\%) } \\
\hline & & & Albu-1 & Albu-2 & Glob & Glut & Rest \\
\hline \multirow[t]{6}{*}{ Amaranth } & Bärnkraft & 0.0 & 10.28 & 3.40 & 53.31 & 4.12 & 28.89 \\
\hline & & 0.8 & 10.33 & 3.55 & 51.66 & 6.29 & 28.17 \\
\hline & & 1.2 & 8.95 & 3.24 & 53.55 & 5.35 & 28.91 \\
\hline & K432 & 0.0 & 7.15 & 2.06 & 47.71 & 9.53 & 33.55 \\
\hline & & 0.8 & 5.40 & 1.93 & 56.17 & 7.15 & 29.36 \\
\hline & & 1.2 & 4.90 & 1.88 & 52.28 & 6.35 & 34.59 \\
\hline \multirow[t]{6}{*}{ Quinoa } & Faro & 0.0 & 8.49 & 7.40 & 53.30 & 4.20 & 26.61 \\
\hline & & 0.8 & 6.40 & 6.29 & 64.55 & 3.04 & 19.72 \\
\hline & & 1.2 & 4.64 & 3.76 & 65.99 & 1.65 & 23.96 \\
\hline & Tango & 0.0 & 14.04 & 0.89 & 54.83 & 5.16 & 25.08 \\
\hline & & 0.8 & 9.70 & 2.01 & 50.60 & 6.15 & 31.54 \\
\hline & & 1.2 & 9.90 & 0.99 & 52.46 & 5.34 & 31.32 \\
\hline
\end{tabular}


Appendix V: Amino acid concentrations of amaranth and quinoa and at different rates of nitrogen applications ( $100 \mathrm{~g}^{-1}$ protein)

\begin{tabular}{|c|c|c|c|c|c|c|c|c|c|c|c|c|}
\hline \multirow{3}{*}{$\begin{array}{l}\text { Plants Species } \\
\text { Varieties } \\
\text { Nitrogen levels } \\
\quad\left(\mathrm{g} \mathrm{N} \mathrm{pot}^{-1}\right) \\
\end{array}$} & \multicolumn{6}{|c|}{ Amaranth } & \multicolumn{6}{|c|}{ Quinoa } \\
\hline & \multicolumn{3}{|c|}{ Bärnkraft } & \multicolumn{3}{|c|}{ K432 } & \multicolumn{3}{|c|}{ Faro } & \multicolumn{3}{|c|}{ Tango } \\
\hline & 0.0 & 0.8 & 1.2 & 0.0 & 0.8 & 1.2 & 0.0 & 0.8 & 1.2 & 0.0 & 0.8 & 1.2 \\
\hline $\begin{array}{l}\text { Amino acid } \\
\text { composition }\end{array}$ & & & & & & & & & & & & \\
\hline Asp & 9.6 & 9.8 & 9.5 & 9.1 & 9.0 & 8.4 & 11.0 & 9.4 & 9.5 & 11.1 & 9.2 & 9.2 \\
\hline Ser & 7.3 & 7.2 & 5.9 & 6.6 & 10.6 & 8.6 & 5.4 & 4.5 & 4.4 & 5.7 & 4.6 & 4.2 \\
\hline Glu & 11.7 & 11.9 & 11.6 & 12.2 & 10.5 & 10.2 & 10.7 & 9.4 & 9.4 & 10.4 & 9.5 & 9.5 \\
\hline His & 2.7 & 2.6 & 2.8 & 2.7 & 2.7 & 2.7 & 2.8 & 2.9 & 2.8 & 2.9 & 3.3 & 3.0 \\
\hline Gly & 6.4 & 5.8 & 4.9 & 6.1 & 10.3 & 9.3 & 3.9 & 3.6 & 3.1 & 4.2 & 3.7 & 3.4 \\
\hline Arg & 12.2 & 11.6 & 13.4 & 13.8 & 11.7 & 11.8 & 12.3 & 13.8 & 13.5 & 12.2 & 14.4 & 14.3 \\
\hline Thr & 3.4 & 3.5 & 3.8 & 3.9 & 3.4 & 3.2 & 4.1 & 3.7 & 4.1 & 4.2 & 3.9 & 3.6 \\
\hline Ala & 8.6 & 8.8 & 8.9 & 8.2 & 8.1 & 8.4 & 10.0 & 9.7 & 10.3 & 8.7 & 9.0 & 9.4 \\
\hline Pro & 6.6 & 6.7 & 7.1 & 6.5 & 6.4 & 6.6 & 7.3 & 7.8 & 8.2 & 8.8 & 9.4 & 9.5 \\
\hline Cys & 3.4 & 3.5 & 3.1 & 2.9 & 1.3 & 3.7 & 2.9 & 3.1 & 3.4 & 2.7 & 2.3 & 2.9 \\
\hline Tyr & 5.0 & 5.1 & 5.5 & 4.9 & 4.5 & 4.9 & 4.8 & 5.7 & 5.5 & 4.7 & 5.4 & 5.3 \\
\hline Val & 3.3 & 3.3 & 3.6 & 3.5 & 3.1 & 3.2 & 4.3 & 4.4 & 4.6 & 4.3 & 4.5 & 4.4 \\
\hline Met & 1.6 & 1.4 & 1.5 & 1.8 & 1.2 & 1.2 & 1.4 & 1.4 & 1.4 & 1.3 & 1.4 & 1.2 \\
\hline Lys & 8.2 & 7.9 & 7.0 & 7.5 & 7.1 & 7.3 & 7.8 & 7.2 & 6.8 & 7.3 & 6.3 & 7.0 \\
\hline Ile & 2.6 & 2.9 & 2.9 & 2.7 & 2.5 & 2.6 & 3.1 & 3.5 & 3.5 & 3.1 & 3.4 & 3.4 \\
\hline Leu & 4.8 & 5.1 & 5.5 & 5.1 & 4.9 & 5.0 & 6.0 & 6.8 & 6.8 & 6.0 & 6.6 & 6.7 \\
\hline Phe & 2.6 & 2.9 & 3.0 & 2.7 & 2.8 & 2.9 & 2.3 & 3.2 & 3.0 & 2.4 & 3.2 & 3.1 \\
\hline EAA & 41.4 & 41.2 & 43.5 & 43.6 & 39.4 & 39.9 & 44.0 & 46.8 & 46.4 & 43.8 & 47.0 & 46.6 \\
\hline
\end{tabular}


Appendix V: Amino acid concentrations in Albu-1 fractions of amaranth and quinoa and at different rates of nitrogen applications $\left(\mathrm{g} 100 \mathrm{~g}^{-1}\right.$ protein)

\begin{tabular}{|c|c|c|c|c|c|c|c|c|c|c|c|c|}
\hline \multirow{3}{*}{$\begin{array}{l}\text { Plants Species } \\
\text { Varieties } \\
\text { Nitrogen levels } \\
\quad\left(\mathrm{g} \mathrm{N} \mathrm{pot}^{-1}\right)\end{array}$} & \multicolumn{6}{|c|}{ Amaranth } & \multicolumn{6}{|c|}{ Quinoa } \\
\hline & \multicolumn{3}{|c|}{ Bärnkraft } & \multicolumn{3}{|c|}{ K432 } & \multicolumn{3}{|c|}{ Faro } & \multicolumn{3}{|c|}{ Tango } \\
\hline & 0.0 & 0.8 & 1.2 & 0.0 & 0.8 & 1.2 & 0.0 & 0.8 & 1.2 & 0.0 & 0.8 & 1.2 \\
\hline $\begin{array}{l}\text { Amino acid } \\
\text { composition }\end{array}$ & & & & & & & & & & & & \\
\hline Asp & 4.5 & 5.5 & 4.5 & 4.5 & 4.3 & 3.4 & 4.7 & 5.0 & 5.1 & 5.5 & 6.9 & 6.8 \\
\hline Ser & 5.5 & 4.5 & 5.3 & 6.1 & 6.3 & 5.3 & 3.9 & 4.3 & 4.2 & 4.4 & 4.8 & 4.6 \\
\hline Glu & 13.8 & 15.1 & 13.9 & 9.8 & 10.7 & 6.5 & 10.7 & 11.7 & 12.7 & 9.2 & 13.3 & 15.8 \\
\hline His & 2.7 & 2.6 & 2.7 & 5.4 & 4.6 & 5.6 & 3.4 & 3.2 & 2.9 & 3.3 & 1.7 & 1.1 \\
\hline Gly & 15.1 & 11.7 & 14.2 & 16.9 & 16.7 & 18.5 & 12.0 & 11.8 & 11.8 & 9.9 & 10.9 & 11.3 \\
\hline Arg & 11.6 & 9.4 & 12.0 & 13.5 & 13.8 & 9.7 & 5.9 & 6.6 & 6.1 & 7.8 & 7.4 & 9.1 \\
\hline Thr & 4.0 & 4.3 & 4.2 & 4.4 & 4.0 & 4.8 & 5.8 & 5.7 & 5.9 & 5.3 & 5.3 & 4.7 \\
\hline Ala & 4.0 & 5.2 & 4.3 & 3.8 & 3.9 & 4.7 & 6.6 & 6.1 & 6.3 & 6.2 & 6.4 & 6.0 \\
\hline Pro & 3.7 & 4.0 & 3.8 & 3.8 & 3.9 & 4.5 & 6.2 & 5.9 & 5.7 & 5.3 & 5.3 & 5.1 \\
\hline Cys & 1.3 & 0.5 & 0.1 & 0.6 & 0.3 & 0.2 & 0.0 & 0.0 & 0.0 & 0.0 & 0.1 & 0.1 \\
\hline Tyr & 5.5 & 5.3 & 5.2 & 4.3 & 4.9 & 6.2 & 5.3 & 5.7 & 5.3 & 5.8 & 4.4 & 4.3 \\
\hline Val & 4.7 & 5.5 & 5.0 & 4.3 & 4.4 & 5.4 & 7.3 & 6.9 & 7.0 & 7.2 & 6.6 & 5.9 \\
\hline Met & 1.9 & 1.9 & 2.0 & 1.6 & 1.6 & 1.8 & 1.8 & 1.7 & 1.5 & 2.2 & 1.9 & 1.7 \\
\hline Lys & 7.8 & 8.6 & 8.0 & 8.5 & 7.4 & 6.8 & 5.4 & 5.5 & 6.5 & 7.4 & 8.2 & 8.1 \\
\hline Ile & 4.0 & 4.7 & 4.4 & 3.9 & 3.9 & 4.9 & 5.9 & 5.6 & 5.6 & 5.6 & 4.7 & 4.3 \\
\hline Leu & 5.3 & 6.3 & 5.7 & 4.8 & 5.0 & 6.1 & 8.4 & 7.8 & 7.7 & 8.3 & 7.1 & 6.6 \\
\hline Phe & 4.8 & 5.0 & 4.9 & 3.8 & 4.4 & 5.5 & 6.6 & 6.4 & 5.8 & 6.4 & 5.0 & 4.6 \\
\hline EAA & 46.7 & 48.2 & 48.7 & 50.1 & 49.0 & 50.7 & 50.5 & 49.4 & 48.9 & 53.7 & 48.0 & 46.1 \\
\hline
\end{tabular}


Appendix VI: Amino acid concentrations in Albu-2 fractions of amaranth and quinoa and at different

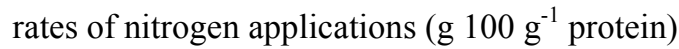

\begin{tabular}{|c|c|c|c|c|c|c|c|c|c|c|c|c|}
\hline \multirow{3}{*}{$\begin{array}{l}\text { Plants Species } \\
\text { Varieties } \\
\text { Nitrogen levels } \\
\quad\left(\mathrm{g} \mathrm{N} \mathrm{pot}^{-1}\right)\end{array}$} & \multicolumn{6}{|c|}{ Amaranth } & \multicolumn{6}{|c|}{ Quinoa } \\
\hline & \multicolumn{3}{|c|}{ Bärnkraft } & \multicolumn{3}{|c|}{ K432 } & \multicolumn{3}{|c|}{ Faro } & \multicolumn{3}{|c|}{ Tango } \\
\hline & 0.0 & 0.8 & 1.2 & 0.0 & 0.8 & 1.2 & 0.0 & 0.8 & 1.2 & 0.0 & 0.8 & 1.2 \\
\hline $\begin{array}{l}\text { Amino acid } \\
\text { composition }\end{array}$ & & & & & & & & & & & & \\
\hline Asp & 8.2 & 9.2 & 8.4 & 8.7 & 9.5 & 8.0 & 9.7 & 9.6 & 9.5 & 9.5 & 9.5 & 8.6 \\
\hline Ser & 6.3 & 5.6 & 6.1 & 6.5 & 6.2 & 5.3 & 4.8 & 3.9 & 4.3 & 4.8 & 5.0 & 4.5 \\
\hline Glu & 13.1 & 15.3 & 15.7 & 12.6 & 13.0 & 10.1 & 15.9 & 14.7 & 14.1 & 12.8 & 12.6 & 12.2 \\
\hline His & 3.1 & 2.8 & 3.2 & 3.0 & 3.4 & 3.0 & 2.2 & 3.1 & 3.0 & 2.9 & 3.1 & 2.7 \\
\hline Gly & 7.8 & 7.2 & 7.3 & 7.5 & 7.2 & 7.3 & 5.9 & 5.9 & 6.6 & 7.4 & 7.6 & 7.4 \\
\hline Arg & 9.4 & 9.1 & 10.5 & 11.1 & 11.0 & 7.2 & 9.0 & 9.6 & 9.8 & 9.4 & 8.7 & 7.4 \\
\hline Thr & 4.4 & 4.5 & 4.4 & 4.7 & 4.5 & 4.5 & 4.4 & 3.9 & 4.3 & 4.7 & 5.2 & 5.6 \\
\hline Ala & 5.3 & 4.8 & 4.7 & 5.1 & 5.3 & 7.1 & 6.0 & 6.9 & 6.3 & 6.9 & 7.3 & 7.6 \\
\hline Pro & 5.2 & 4.8 & 5.0 & 4.7 & 4.8 & 5.4 & 4.4 & 4.8 & 4.7 & 4.6 & 5.0 & 4.9 \\
\hline Cys & 0.7 & 0.0 & 0.0 & 0.0 & 0.1 & 0.2 & 0.0 & 0.0 & 0.0 & 0.0 & 0.0 & 0.0 \\
\hline Tyr & 4.9 & 4.6 & 4.2 & 4.7 & 4.3 & 5.2 & 4.0 & 4.2 & 4.4 & 4.2 & 4.6 & 7.6 \\
\hline Val & 6.1 & 6.2 & 5.8 & 6.0 & 5.7 & 7.2 & 6.5 & 6.5 & 6.3 & 6.9 & 4.6 & 5.0 \\
\hline Met & 1.2 & 1.3 & 1.1 & 0.9 & 0.8 & 0.9 & 1.4 & 1.5 & 1.4 & 1.0 & 0.9 & 1.3 \\
\hline Lys & 5.3 & 6.5 & 5.5 & 6.0 & 6.4 & 6.6 & 7.1 & 6.6 & 6.6 & 6.8 & 7.3 & 7.2 \\
\hline Ile & 5.4 & 5.3 & 5.1 & 5.3 & 5.1 & 6.2 & 5.5 & 5.6 & 5.4 & 5.5 & 5.5 & 5.4 \\
\hline Leu & 7.8 & 7.3 & 7.2 & 7.5 & 7.3 & 8.9 & 8.1 & 8.2 & 8.2 & 8.0 & 8.0 & 8.1 \\
\hline Phe & 6.0 & 5.7 & 5.8 & 5.7 & 5.4 & 6.7 & 4.9 & 5.1 & 5.0 & 4.7 & 5.1 & 4.7 \\
\hline EAA & 48.6 & 48.6 & 48.7 & 50.1 & 49.6 & 51.3 & 49.1 & 49.9 & 50.1 & 49.9 & 48.4 & 47.2 \\
\hline
\end{tabular}


Appendix VII: Amino acid concentrations in Glob fractions of amaranth and quinoa and at different rates of nitrogen applications $\left(\mathrm{g} 100 \mathrm{~g}^{-1}\right.$ protein)

\begin{tabular}{|c|c|c|c|c|c|c|c|c|c|c|c|c|}
\hline \multirow{3}{*}{$\begin{array}{l}\text { Plants Species } \\
\text { Varieties } \\
\text { Nitrogen levels } \\
\quad\left(\mathrm{g} \mathrm{N} \mathrm{pot}^{-1}\right)\end{array}$} & \multicolumn{6}{|c|}{ Amaranth } & \multicolumn{6}{|c|}{ Quinoa } \\
\hline & \multicolumn{3}{|c|}{ Bärnkraft } & \multicolumn{3}{|c|}{ K432 } & \multicolumn{3}{|c|}{ Faro } & \multicolumn{3}{|c|}{ Tango } \\
\hline & 0.0 & 0.8 & 1.2 & 0.0 & 0.8 & 1.2 & 0.0 & 0.8 & 1.2 & 0.0 & 0.8 & 1.2 \\
\hline $\begin{array}{l}\text { Amino acid } \\
\text { composition }\end{array}$ & & & & & & & & & & & & \\
\hline Asp & 2.8 & 3.1 & 2.8 & 3.0 & 3.9 & 2.6 & 2.8 & 2.9 & 3.0 & 3.0 & 2.9 & 3.4 \\
\hline Ser & 4.2 & 4.6 & 4.1 & 3.5 & 3.7 & 3.7 & 3.4 & 3.3 & 3.3 & 4.3 & 3.6 & 3.8 \\
\hline Glu & 9.8 & 10.5 & 10.4 & 11.5 & 14.0 & 10.6 & 11.4 & 12.7 & 12.5 & 10.4 & 10.9 & 11.0 \\
\hline His & 4.2 & 4.0 & 3.9 & 4.0 & 3.9 & 4.5 & 5.8 & 6.6 & 6.5 & 4.9 & 5.4 & 5.2 \\
\hline Gly & 6.4 & 8.6 & 7.7 & 7.6 & 6.9 & 7.9 & 6.2 & 5.8 & 5.7 & 7.5 & 6.4 & 6.5 \\
\hline Arg & 15.3 & 17.8 & 15.8 & 14.9 & 12.6 & 12.9 & 19.6 & 20.3 & 20.0 & 18.3 & 19.8 & 17.6 \\
\hline Thr & 4.1 & 3.6 & 3.8 & 3.8 & 3.9 & 4.1 & 4.4 & 5.4 & 4.7 & 3.9 & 4.4 & 4.6 \\
\hline Ala & 9.0 & 8.4 & 10.5 & 9.2 & 7.7 & 9.7 & 7.2 & 5.0 & 4.6 & 7.4 & 7.5 & 7.1 \\
\hline Pro & 4.8 & 4.3 & 4.7 & 5.1 & 4.9 & 5.3 & 4.7 & 3.7 & 3.4 & 4.5 & 4.4 & 4.4 \\
\hline Cys & 0.3 & 0.0 & 0.0 & 0.0 & 0.1 & 0.0 & 0.0 & 0.0 & 0.0 & 0.0 & 0.0 & 0.0 \\
\hline Tyr & 7.2 & 7.2 & 6.7 & 6.8 & 6.9 & 7.7 & 6.9 & 8.4 & 8.7 & 6.2 & 6.3 & 6.4 \\
\hline Val & 4.9 & 4.2 & 4.7 & 4.7 & 5.1 & 5.0 & 4.0 & 3.7 & 3.9 & 4.4 & 4.4 & 4.9 \\
\hline Met & 3.3 & 2.9 & 2.6 & 3.2 & 2.3 & 2.1 & 3.0 & 2.1 & 2.1 & 3.9 & 2.3 & 2.2 \\
\hline Lys & 3.3 & 2.7 & 3.5 & 3.6 & 3.8 & 2.8 & 2.7 & 0.9 & 0.8 & 3.6 & 3.3 & 3.5 \\
\hline Ile & 4.8 & 4.1 & 4.6 & 4.6 & 5.1 & 5.0 & 4.1 & 3.8 & 4.2 & 4.6 & 4.4 & 4.8 \\
\hline Leu & 6.9 & 5.6 & 5.9 & 6.1 & 6.6 & 6.5 & 6.1 & 5.6 & 5.9 & 6.6 & 6.5 & 6.9 \\
\hline Phe & 8.9 & 8.7 & 8.4 & 8.3 & 8.5 & 9.7 & 7.6 & 10.1 & 10.8 & 6.7 & 7.4 & 7.7 \\
\hline EAA & 55.5 & 53.4 & 53.1 & 53.2 & 52.0 & 52.5 & 57.3 & 58.5 & 58.9 & 56.8 & 57.9 & 57.4 \\
\hline
\end{tabular}


Appendix VIII: Amino acid concentrations in Glut fractions of amaranth and quinoa and at different rates of nitrogen applications $\left(\mathrm{g} 100 \mathrm{~g}^{-1}\right.$ protein)

\begin{tabular}{|c|c|c|c|c|c|c|c|c|c|c|c|c|}
\hline \multirow{3}{*}{$\begin{array}{l}\text { Plants Species } \\
\text { Varieties } \\
\text { Nitrogen levels } \\
\quad\left(\mathrm{g} \mathrm{N} \mathrm{pot}^{-1}\right)\end{array}$} & \multicolumn{6}{|c|}{ Amaranth } & \multicolumn{6}{|c|}{ Quinoa } \\
\hline & \multicolumn{3}{|c|}{ Bärnkraft } & \multicolumn{3}{|c|}{ K432 } & \multicolumn{3}{|c|}{ Faro } & \multicolumn{3}{|c|}{ Tango } \\
\hline & 0.0 & 0.8 & 1.2 & 0.0 & 0.8 & 1.2 & 0.0 & 0.8 & 1.2 & 0.0 & 0.8 & 1.2 \\
\hline \multicolumn{13}{|l|}{$\begin{array}{l}\text { Amino acid } \\
\text { composition }\end{array}$} \\
\hline Asp & 10.3 & 9.7 & 9.8 & 8.6 & 9.4 & 9.8 & 10.1 & 9.7 & 9.9 & 9.0 & 9.5 & 9.8 \\
\hline Ser & 5.9 & 5.6 & 5.7 & 6.1 & 5.6 & 5.5 & 5.2 & 5.2 & 5.1 & 5.2 & 5.4 & 5.4 \\
\hline Glu & 12.8 & 13.7 & 13.9 & 15.8 & 17.4 & 18.0 & 16.5 & 16.8 & 16.9 & 10.7 & 12.6 & 12.5 \\
\hline His & 2.7 & 3.0 & 2.9 & 3.1 & 3.0 & 2.8 & 3.2 & 3.2 & 3.0 & 3.2 & 3.4 & 3.3 \\
\hline Gly & 6.3 & 6.3 & 6.2 & 6.2 & 5.9 & 5.7 & 5.5 & 5.7 & 5.6 & 5.9 & 5.8 & 5.9 \\
\hline Arg & 8.2 & 9.4 & 9.9 & 10.1 & 10.0 & 9.6 & 8.7 & 9.0 & 8.8 & 8.9 & 10.1 & 9.8 \\
\hline Thr & 5.1 & 4.6 & 4.5 & 4.6 & 3.9 & 3.8 & 4.2 & 4.1 & 4.1 & 5.0 & 4.7 & 4.8 \\
\hline Ala & 5.3 & 4.6 & 4.6 & 4.8 & 4.8 & 4.9 & 5.7 & 5.3 & 5.3 & 5.8 & 5.4 & 5.6 \\
\hline Pro & 4.8 & 5.1 & 5.2 & 4.5 & 4.9 & 4.8 & 4.1 & 4.2 & 4.2 & 4.5 & 4.4 & 4.5 \\
\hline Cys & 2.6 & 2.4 & 2.4 & 1.1 & 1.0 & 1.6 & 2.0 & 1.5 & 1.4 & 0.7 & 1.0 & 0.8 \\
\hline Tyr & 4.9 & 5.3 & 5.0 & 5.1 & 4.8 & 4.4 & 4.1 & 4.0 & 4.2 & 5.7 & 4.8 & 4.7 \\
\hline Val & 5.9 & 5.5 & 5.4 & 5.6 & 5.5 & 5.4 & 6.0 & 5.9 & 6.0 & 6.5 & 6.0 & 6.2 \\
\hline Met & 1.1 & 1.2 & 1.0 & 0.8 & 0.8 & 0.8 & 1.2 & 1.4 & 1.3 & 1.8 & 1.6 & 1.6 \\
\hline Lys & 5.7 & 5.1 & 5.3 & 4.8 & 4.9 & 5.3 & 5.4 & 5.2 & 5.4 & 5.8 & 5.2 & 5.4 \\
\hline Ile & 5.4 & 5.6 & 5.5 & 5.4 & 5.3 & 5.2 & 5.3 & 5.4 & 5.5 & 5.8 & 5.7 & 5.7 \\
\hline Leu & 8.2 & 7.7 & 7.6 & 8.0 & 7.8 & 7.6 & 8.5 & 8.3 & 8.4 & 9.5 & 8.7 & 8.8 \\
\hline Phe & 4.8 & 5.3 & 5.2 & 5.3 & 5.1 & 4.9 & 4.6 & 4.9 & 5.0 & 6.1 & 5.7 & 5.4 \\
\hline EAA & 47.1 & 47.3 & 47.3 & 47.8 & 46.2 & 45.4 & 47.0 & 47.5 & 47.4 & 52.6 & 50.9 & 50.9 \\
\hline
\end{tabular}




\section{Acknowledgements}

I would like sincerely thank my supervisor Prof. Dr. Elke Pawelzik for her kindness, guidance and great enthusiasms to critical read the manuscripts, and improve the whole work. I learned from her considerably broadened my academic capability. I would like to thank Prof. Dr. Norbert Claassen for the kind acceptance to be my Coreferee; Dr. Therdchai Vearasilp and Prof. Dr. Udo ter Meulen for co-operation project between Chiangmai University, Thailand and Georg-August University, Gö ttingen, Germany; Dr. Efren Delgado for his valuable guidance of research project; Dr. Anna Keutgen for very helpful comments throughout the study period; Dr. Gerhard Sauerbeck from Institute of Crop and Grassland Science, Federal Agriculture Research Centre, Braunschweig, Germany, for his useful comments and the seed material; Dr. Ernst Kübler from University of Hohenheim for the seed material; Prof. Dr. Wilhelm Römer for his kind comments about fertilizer application; Dr. Bernd Steingrobe for his valuable discussions.

The experimental work would not have been success without the highly appreciated assistance and support of the staff of the Institute of Agriculture Chemistry, with special thanks to Cornelia Conradt. I also thank Susanne Koch, Reinhard Hilmer, Jü rgen Kobbe, Marco Hanke, Gunda Jansen, Bettina Egger, Claudia Hof, Herry Heriyati Permady, Jinhua Wang, Erika Pardede and Ikhsan Sulaiman. The participation of the staff of the Institute of Agronomy and Plant Breeding, for fatty acids analysis, namely, Uwe Ammermann and Nicole Ritgen-Homayounfar, is acknowledged.

This study was financed by the Ministry of Science and Culture, Niedersachsen, Hannover, Germany and the Postharvest Technology Institute, Chiangmai University, Thailand, which I highly appreciate.

Thank are due to all my colleagues in the Institute of Agricultural Chemistry for the help and pleasant working atmosphere. I especially thank Nelson Castañeda-Ortiz for his valuable suggestions.

Thank to all my Thai friends, too many to list here, for their genial friendship.

Finally, I would like to thank Dr. Suchada Vearasilp, all my teachers and my family. To them I would like to dedicate this piece of work.

Any mistakes, which might appear in this thesis, are entirely mine. 


\section{Curriculum Vitae}

Name

Date of birth

Place of birth

\section{Education}

1976-1980

1980-1982

1982-1988

1988-1992

1992-1996

Since July 2001

\section{Employment}

1996-1997

Since December 1997
Sa-nguansak Thanapornpoonpong

12 March 1970

Phayao, Thailand

Boonsitvittaya Primary school, Phayao

Assumption Primary school, Lampang

Phayaophittayakom High school, Phayao

Faculty of Agriculture, Department of, Agronomy,

Chiang Mai University, Chiang Mai, Thailand :

B.Sc. (Agriculture)

Faculty of Agriculture, Department of, Agronomy,

Chiang Mai University, Chiang Mai, Thailand :

M.Sc. (Agriculture)

PhD student at Georg-August University Göttingen,

Institute of Agriculture Chemistry

Quality Assurance Officer, Bangkok Seed Industry Co, Ltd., Lopburi, Thailand

Lecturer, Department of Agronomy,

Faculty of Agriculture, Chiang Mai University,

Chiang Mai, Thailand 